\title{
Identification of a RIP1 Kinase Inhibitor Clinical Candidate (GSK3145095) for the Treatment of Pancreatic Cancer
}

Philip A. Harris, ${ }^{* \dagger}$ Jill M. Marinis,${ }^{\dagger}$ John D. Lich, ${ }^{\dagger}$ Scott B. Berger, ${ }^{\dagger}$ Anirudh Chirala, ${ }^{\#}$ Julie A. Cox, ${ }^{\star}$ Patrick M. Eidam,${ }^{\dagger}$ Joshua N. Finger, ${ }^{\dagger}$ Peter J. Gough,${ }^{\dagger}$ Jae U. Jeong, ${ }^{\dagger}$ James Kang, ${ }^{\dagger}$ Viera Kasparcova, ${ }^{\dagger}$ Lara K. Leister,${ }^{\dagger}$ Mukesh K. Mahajan, ${ }^{\dagger}$ George Miller, ${ }^{\# \S}$ Rakesh Nagilla, ${ }^{\dagger}$ Michael T. Ouellette, ${ }^{\ddagger}$ Michael A. Reilly ${ }^{\dagger}$ Alan R. Rendina, ${ }^{\dagger}$ Elizabeth J. Rivera ${ }^{\dagger}$ Helen H. Sun, ${ }^{\dagger}$ James H. Thorpe, ${ }^{\S}$ Rachel D. Totoritis, ${ }^{\ddagger}$ Wei Wang, ${ }^{\#}$ Dongling Wu, ${ }^{\#}$ Daohua Zhang, ${ }^{\dagger}$ John Bertin ${ }^{\dagger}$ and Robert W. Marquis ${ }^{\dagger}$

†Pattern Recognition Receptor DPU and \$Platform Technology \& Science, GlaxoSmithKline, Collegeville Road, Collegeville, Pennsylvania 19426, USA

$\S$ Platform Technology \& Science, GlaxoSmithKline, Gunnels Wood Road, Stevenage, Hertfordshire SG1 2NY, UK

${ }^{\#}$ S. Arthur Localio Laboratory, ${ }^{\S}$ Department of Cell Biology, New York University School of Medicine, 550 First Avenue, New York, NY 10016, USA

\section{CONTENTS}

1. Preparation of Compounds 2, 3, 6-11

2. Enzyme preparation

3. In vitro assays

4. Mode of inhibition of Compound 6

5. Compound 6 enzyme kinetics

6. Compound 6 kinase selectivity and RIP1 species selectivity profiles

7. Compound 6 RIP1 co-crystallization

8. Compound 6: rat tissue distribution, permeability and P-gp substrate evaluation, hepataocyte turnover and human PK/PD predictions

9. Additional PDOTS evaluation

10. References 


\section{Preparation of Compounds 2, 3, 6-11}

The route to prepare benzoxazepinones $\mathbf{2 , 3 , 7}$ and $\mathbf{8}$ has been described previously starting from BOC-L-serine and is detailed in Scheme 1.22 The unsubstituted (S)-3-amino-benzazepin2-one is commercially available and can be converted to inhibitors $\mathbf{9}$ and $\mathbf{1 0}$ as shown in Scheme 2. The inhibitors $\mathbf{6}$ and $\mathbf{1 1}$ were obtained via 7,9-difluoro-benzoazepin-2-one prepared starting from 6,8-difluoro-tetralone, conversion to the tosylate oxime and Beckmann rearrangement as outlined in Scheme 3. Conversion to the $\alpha$-iodolactam, followed by displacement with azide and subsequent Staudinger reduction yielded the 3-amino-7,9difluoro-benzoazepin-2-one. The stereochemistry is set via a dynamic kinetic resolution using D-pyroglutamic acid and 3,5-dichlorosalicylaldehyde as catalyst. Coupling with 5-benzyltriazole-3-carboxylic acid before or after methylation of the lactam nitrogen yielded $\mathbf{6}$ and $\mathbf{1 1}$.

Scheme 1.
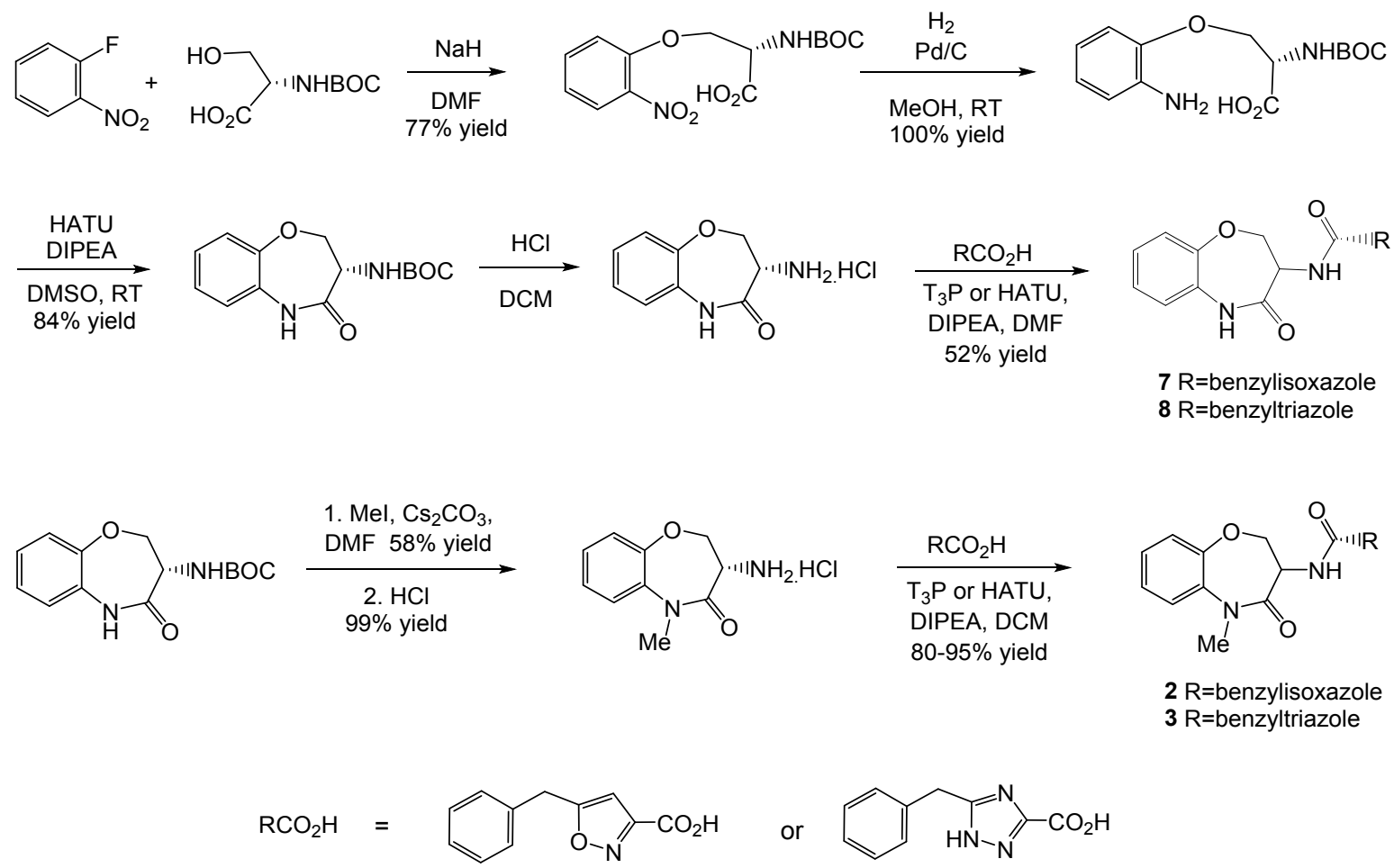
Scheme 2.

1. $\mathrm{Mel}, \mathrm{K}_{2} \mathrm{CO}_{3}$, DMF $78 \%$ yield<smiles>O=C(O)N[C@@H]1CCc2ccccc2NC1=O</smiles>

2. $\mathrm{HCl} /$ dioxane

3. $\mathrm{RCO}_{2} \mathrm{H}$

$\mathrm{T}_{3} \mathrm{P}$ DIPEA, DCM

$7 \%$ yield<smiles>CN1C(=O)C(NC(=O)c2n[nH]c(Cc3ccccc3)n2)CCc2ccccc21</smiles><smiles>N[C@@H]1CCc2ccccc2NC1=O</smiles>

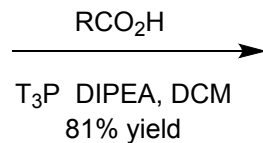<smiles>O=C(NC1CCc2ccccc2NC1=O)c1n[nH]c(Cc2ccccc2)n1</smiles>

10

Scheme 3.<smiles>O=C1CCCc2cc(F)cc(F)c21</smiles>

$\mathrm{NH}_{2} \mathrm{OH}-\mathrm{HCl}, \mathrm{NaOAC}$

$\underset{96 \% \text { yield }}{\stackrel{\mathrm{EtOH}_{(\mathrm{aq})}}{\longrightarrow}}$<smiles>ON=C1CCCc2cc(F)cc(F)c21</smiles>

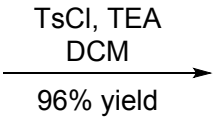<smiles>Fc1cc(F)c2c(c1)CCC/C2=N\[As]</smiles><smiles>CC(C)(C)[Mg][Mg]</smiles><smiles>O=C1CCCc2cc(F)cc(F)c2N1</smiles>

a) TMEDA, TMSI

b) $\mathrm{I}_{2}$ $94 \%$ yield<smiles>O=C1Nc2c(F)cc(F)cc2CCC1I</smiles>

a) $\mathrm{NaN}_{3}, \mathrm{DMF}$,

b) $\mathrm{PPh}_{3}$ resin, $\mathrm{THF}_{(\mathrm{aq})}$

$80 \%$ yield (2 steps)<smiles>NC1CCc2cc(F)cc(F)c2NC1=O</smiles>

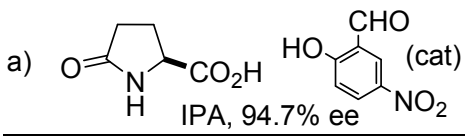

b) $\mathrm{ACN}_{(\mathrm{aq})}, 99.6 \% \mathrm{ee}$

c) $\mathrm{NH}_{4} \mathrm{OH}_{(\mathrm{aq})}$

$70 \%$ yield for 3 steps

$\mathrm{RCO}_{2} \mathrm{H}$, T3P, DIPEA, DCM $88 \%$ yield<smiles>O=C(N[C@H]1CCc2cc(F)cc(F)c2NC1=O)c1nnc(Cc2ccccc2)[nH]1</smiles>

1. $\mathrm{BOC}_{2} \mathrm{O}, \mathrm{TEA}, \mathrm{DCM}$

$$
98 \% \text { yield }
$$

2. Mel, $\mathrm{Cs}_{2} \mathrm{CO}_{3}$, DMF<smiles>N[C@@H]1CCc2cc(F)cc(F)c2NC1=O</smiles>

3. $\mathrm{HCl} /$ dioxane, $99 \%$ yield

4. $\mathrm{RCO}_{2} \mathrm{H}$

$\mathrm{T}_{3} \mathrm{P}$ DIPEA, DCM

$64 \%$ yield<smiles>CN1C(=O)[C@H](NC(=O)c2nnc(Cc3ccccc3)[nH]2)CCc2cc(F)cc(F)c21</smiles>

11<smiles>Cc1cc(F)c2c(c1)CC[C@@H](N)C(=O)N2</smiles> 


\section{EXPERIMENTAL}

General Methods. Unless otherwise noted, starting materials and reagents were purchased from commercial sources and used without further purification. Air or moisture sensitive reactions were carried out under a nitrogen atmosphere. Anhydrous solvents were obtained from SigmaAldrich. -Silica gel chromatography was performed using under standard techniques or using silica gel cartridges (RediSep normal phase disposable flash columns) on an Isco CombiFlash. Reverse phase HPLC purification was conducted on a Gilson HPLC (monitoring at a wavelength of 214 or $254 \mathrm{~nm}$ ) with a YMC ODS-A C18 column ( $5 \mu \mathrm{m}, 75 \mathrm{~mm} 30 \mathrm{~mm})$, eluting with $5-90 \% \mathrm{CH}_{3} \mathrm{CN}$ in $\mathrm{H}_{2} \mathrm{O}$ with $0.1 \%$ TFA unless otherwise noted. ${ }^{1} \mathrm{H}$ NMR spectra were recorded on a Bruker Advance or Varian Unity $400 \mathrm{MHz}$ spectrometer as solutions in DMSO$\mathrm{d}_{6}$ (unless otherwise stated). Chemical shifts $(\delta)$ are reported in ppm relative to an internal solvent reference. Apparent peak multiplicities are described as s (singlet), br s (broad singlet), $\mathrm{d}$ (doublet), dd (doublet of doublets), t (triplet), q (quartet), or m (multiplet). Coupling constants $(\mathrm{J})$ are reported in hertz $(\mathrm{Hz})$ after the integration.

Sciex LCMS analysis was performed on a PE Sciex Single Quadrupole 150EX, using a Thermo Hypersil Gold (C18, $20 \times 2.1 \mathrm{~mm}, 1.9$ u particle diam.), 4-95\% $\mathrm{CH}_{3} \mathrm{CN}: \mathrm{H}_{2} \mathrm{O}$ (with $0.02 \% \mathrm{TFA}$ ) over $2 \mathrm{~min}$., flow rate $=1.4 \mathrm{~mL} / \mathrm{min}$. at $55^{\circ} \mathrm{C}$. Waters LCMS was performed using the same column and conditions as for Sciex except using a Waters Acquity SQD UPLC/MS system. All tested compounds were determined to be $\geq 95 \%$ purity by LCMS.

The following compounds were prepared as described previously: (S)-5-benzyl- $N$-(5-methyl4-oxo-2,3,4,5-tetrahydrobenzo[b]-[1,4]oxazepin-3-yl)isoxazole-3-carboxamide (2), (S)-5benzyl- $N$-(5-methyl-4-oxo-2,3,4,5-tetrahydrobenzo[b][1,4]oxazepin-3-yl)-4H-1,2,4-triazole3-carboxamide (3) and (S)-5-benzyl- $N$-(4-oxo-2,3,4,5-tetrahydrobenzo[b][1,4]-oxazepin-3yl)isoxazole-3-carboxamide (7). ${ }^{22}$

The following intermediates were prepared as described previously: (S)-tert-butyl (4-oxo2,3,4,5-tetrahydrobenzo[b][1,4]oxazepin-3-yl)carbamate, (S)-3-amino-2,3dihydrobenzo[b][1,4]oxazepin-4(5H)-one hydrochloride, and 5-benzyl-4H-1,2,4-triazole-3carboxylic acid. ${ }^{22}$

The following intermediates are commercially available: (S)-3-amino-1,3,4,5-tetrahydro-2Hbenzo[b]azepin-2-one, tert-butyl (S)-(2-oxo-2,3,4,5-tetrahydro-1H-benzo[b]azepin-3yl)carbamate and 5-benzyl-3-isoxazolecarboxylic acid.

(S)-5-Benzyl-N-(7,9-difluoro-2-oxo-2,3,4,5-tetrahydro-1H-benzo[b]azepin-3-yl)-4H1,2,4-triazole-3-carboxamide (6). To a solution of 6,8-difluoro-3,4-dihydronaphthalen$1(2 \mathrm{H})$-one $(50 \mathrm{~g}, 274 \mathrm{mmol})$ in $\mathrm{EtOH}(500 \mathrm{~mL})$ and water $(167 \mathrm{~mL})$ was added sodium acetate $(33.8 \mathrm{~g}, 412 \mathrm{mmol})$ and hydroxylamine hydrochloride $(28.6 \mathrm{~g}, 412 \mathrm{mmol})$. The reaction turned from a light pink to light yellow after hydroxylamine hydrochloride was added and a precipitate formed after $5 \mathrm{~min}$. The reaction was stirred at rt for $150 \mathrm{~min}$., after which water $(500 \mathrm{~mL})$ was added and the solids were filtered off and rinsed with water. The solid was dried to give (E)-6,8-difluoro-3,4-dihydronaphthalen-1(2H)-one oxime as an off-white solid (51.2 g). On sitting for $18 \mathrm{~h}$, a small amount of additional product had precipitated from the filtrate. This was also filtered, washed with water and dried to give additional product $(0.95 \mathrm{~g})$. Total yield $52.15 \mathrm{~g}$ (96\% yield). ${ }^{1} \mathrm{H}$ NMR (400 MHz, DMSO- $d_{6}$ ) $\delta$ ppm 1.71 (quin, $J=6.38 \mathrm{~Hz}, 2 \mathrm{H}$ ), 2.60 - 2.84 (m, 4 H), 6.90 - 7.04 (m, 1 H), 7.09 (ddd, $J=11.75,9.35,2.65$ Hz, 1 H), 11.33 (s, 1 H). LCMS $\mathrm{C}_{10} \mathrm{H}_{9} \mathrm{~F}_{2} \mathrm{NO}(\mathrm{m} / \mathrm{z}): 198\left(\mathrm{M}+\mathrm{H}^{+}\right)$, $>99 \%$ purity.

To a suspension of (E)-6,8-difluoro-3,4-dihydronaphthalen-1(2H)-one oxime (52.2 g, 265 $\mathrm{mmol})$ in DCM $(600 \mathrm{~mL})$ was added TEA $(55.3 \mathrm{~mL}, 397 \mathrm{mmol})$. The reaction was cooled in an ice water bath and p-toluenesulfonyl chloride (53 g, $278 \mathrm{mmol})$ added. The ice bath was 
removed and the reaction stirred at $\mathrm{rt}$ for $22 \mathrm{~h}$. The reaction solution was then washed with water $(2 \times 350 \mathrm{~mL}), 5 \%$ citric acid and brine. Concentration of the DCM solution resulted in an orange-tan solid which was dried to give (E)-6,8-difluoro-3,4-dihydronaphthalen-1(2H)one O-tosyl oxime (92.1 g, 96\% yield). ${ }^{1} \mathrm{H}$ NMR (400 MHz, DMSO- $\left.d_{6}\right) \delta$ ppm 1.71 (quin, $J=6.32 \mathrm{~Hz}, 2 \mathrm{H}), 2.42(\mathrm{~s}, 3 \mathrm{H}), 2.75(\mathrm{t}, J=6.06 \mathrm{~Hz}, 2 \mathrm{H}), 2.82(\mathrm{t}, J=6.57 \mathrm{~Hz}, 2 \mathrm{H}), 7.05-7.13$ (m, $1 \mathrm{H}), 7.19$ (ddd, $J=11.49,9.22,2.53 \mathrm{~Hz}, 1 \mathrm{H}), 7.48$ (d, $J=8.08 \mathrm{~Hz}, 2 \mathrm{H}), 7.86$ (d, $J=8.34$ $\mathrm{Hz}, 2 \mathrm{H})$. LCMS C $17 \mathrm{H}_{15} \mathrm{~F}_{2} \mathrm{NO}_{3} \mathrm{~S}(\mathrm{~m} / \mathrm{z}): 352\left(\mathrm{M}+\mathrm{H}^{+}\right), 98 \%$ purity.

Trifluoroacetic acid $(220 \mathrm{~mL})$ was added to (E)-6,8-difluoro-3,4-dihydronaphthalen-1(2H)one O-tosyl oxime $(92.1 \mathrm{~g}, 262 \mathrm{mmol})$ and the reaction mixture was stirred at $50{ }^{\circ} \mathrm{C}$ for 10 min. After $10 \mathrm{~min}$ the reaction was cooled in an ice/water bath and then quenched with cold water $(1000 \mathrm{~mL})$ over $5 \mathrm{~min}$. The reaction mixture was stirred vigorously for $30 \mathrm{~min}$ in the ice bath and the resulting precipitate filtered off and washed with water. The crude product was stirred in 9:1 hexanes/ $\mathrm{Et}_{2} \mathrm{O}(500 \mathrm{~mL})$, filtered off and resuspended in 3:1 hexanes/ $/ \mathrm{Et}_{2} \mathrm{O}(500$ $\mathrm{mL})$, filtered off and resuspended in $\mathrm{Et}_{2} \mathrm{O}(250 \mathrm{~mL})$. The resulting solid was filtered off, and dried in vacuum oven to give 7,9-difluoro-4,5-dihydro-1H-benzo[b]azepin-2(3H)-one $(33.9 \mathrm{~g}$, $60 \%$ yield) as a light brown solid. ${ }^{1} \mathrm{H}$ NMR (400 MHz, DMSO- $\left.d_{6}\right) \delta$ ppm $2.03-2.23(\mathrm{~m}, 4$ H), $2.73(\mathrm{t}, J=6.82 \mathrm{~Hz}, 2 \mathrm{H}), 6.99-7.11$ (m, $1 \mathrm{H}), 7.20$ (ddd, $J=10.29,9.16,2.78 \mathrm{~Hz}, 1 \mathrm{H})$, $9.40(\mathrm{~s}, 1 \mathrm{H})$. LCMS C ${ }_{10} \mathrm{H}_{9} \mathrm{~F}_{2} \mathrm{NO}(\mathrm{m} / \mathrm{z}): 198\left(\mathrm{M}+\mathrm{H}^{+}\right), 94 \%$ purity.

To a mixture of 7,9-difluoro-4,5-dihydro-1H-benzo[b]azepin-2(3H)-one (33.9 g, $172 \mathrm{mmol})$ in DCM (400 mL) cooled in an ice/water bath was added TMEDA (51.9 mL, $344 \mathrm{mmol}$ ), followed by TMSI ( $46.8 \mathrm{~mL}, 344 \mathrm{mmol})$ dropwise over $25 \mathrm{~min}$. The light brown solution was stirred in the ice-bath for $60 \mathrm{~min}$, and then iodine $(65.4 \mathrm{~g}, 258 \mathrm{mmol})$ was added and mixture was stirred in the ice-bath for another $60 \mathrm{~min}$. The reaction was quenched with aq. sodium thiosulfate, and stirred for $15 \mathrm{~min}$. The resulting solid was filtered off, washed with water and DCM, and then dried in vacuum to give 7,9-difluoro-3-iodo-4,5-dihydro-1H-benzo[b]azepin$2(3 \mathrm{H})$-one (37.6 g, 66\% yield) as a tan solid. The organic layer from the filtrate was separated and combined with DCM washes and this was washed with water and brine and concentrated. The resulting solid was triturated in $50 \mathrm{~mL}$ of ethyl acetate, filtered and dried to give additional product as an off-white solid (15.7 g, 28\% yield). ${ }^{1} \mathrm{H}$ NMR (400 MHz, DMSO- $\left.d_{6}\right) \delta$ ppm 2.53 - $2.65(\mathrm{~m}, 1 \mathrm{H}), 2.65$ - $2.81(\mathrm{~m}, 3 \mathrm{H}), 4.61$ - $4.76(\mathrm{~m}, 1 \mathrm{H}), 6.99$ - $7.16(\mathrm{~m}, 1 \mathrm{H}), 7.16$ - 7.33 (m, $1 \mathrm{H}), 9.85(\mathrm{~s}, 1 \mathrm{H})$. LCMS C ${ }_{10} \mathrm{H}_{8} \mathrm{~F}_{2} \mathrm{INO}(\mathrm{m} / \mathrm{z}): 324\left(\mathrm{M}+\mathrm{H}^{+}\right),>99 \%$ purity.

To 7,9-difluoro-3-iodo-4,5-dihydro-1H-benzo[b]azepin-2(3H)-one $(53.2 \mathrm{~g}, 165 \mathrm{mmol})$ in DMF $(400 \mathrm{~mL})$ was added sodium azide $(12.85 \mathrm{~g}, 198 \mathrm{mmol})$ and the mixture stirred at rt for $45 \mathrm{~min}$. To the reaction was added ice-water $(300 \mathrm{~mL})$, then further diluted with water $(500$ $\mathrm{mL}$ ) resulting in precipittaion of a solid. The reaction was filtered to give 3-azido-7,9-difluoro4,5-dihydro-1H-benzo[b]azepin-2(3H)-one as a tan solid. This was washed with water and used without further purification or drying. ${ }^{1} \mathrm{H}$ NMR (400 MHz, DMSO- $\left.d_{6}\right) \delta$ ppm $2.03-2.21$ $(\mathrm{m}, 1 \mathrm{H}) 2.29$ - $2.47(\mathrm{~m}, 1 \mathrm{H}) 2.73-2.85(\mathrm{~m}, 2 \mathrm{H}) 4.01$ (dd, $J=11.37,8.08 \mathrm{~Hz}, 1 \mathrm{H}) 7.10$ (d, $J=8.84 \mathrm{~Hz}, 1 \mathrm{H}) 7.16-7.31(\mathrm{~m}, 1 \mathrm{H}) 9.98(\mathrm{~s}, 1 \mathrm{H})$. LCMS (m/z): $239\left(\mathrm{M}+\mathrm{H}^{+}\right), 99 \%$ purity. To a solution of 3-azido-7,9-difluoro-4,5-dihydro-1H-benzo[b]azepin-2(3H)-one (direct from previous step) in THF $(400 \mathrm{~mL})$ was added water $(2 \mathrm{~mL})$ and $\mathrm{PPh}_{3}$ resin $(66 \mathrm{~g}, 3 \mathrm{mmol} / \mathrm{g}$ loading, $198 \mathrm{mmol})$ ]. The reaction was stirred at $\mathrm{rt}$ for $24 \mathrm{~h}$ and then filtered through a small celite plug to remove the resin, rinsed with THF and the filtrate concentrated. The solid was triturated in $\mathrm{Et}_{2} \mathrm{O}$, filtered and dried to give 3-amino-7,9-difluoro-4,5-dihydro-1Hbenzo[b]azepin-2(3H)-one $\left(28.43 \mathrm{~g}, 80 \%\right.$ yield over 2 steps) as an off-white solid. ${ }^{1} \mathrm{H}$ NMR $\left(400 \mathrm{MHz}, \mathrm{DMSO}-d_{6}\right.$ ) $\delta \mathrm{ppm} 1.76(\mathrm{dtd}, J=17.91,6.46,6.46,2.78 \mathrm{~Hz}, 1 \mathrm{H}), 2.14$ - 2.35 (m, 1 H), 2.62 - 2.74 (m, $2 \mathrm{H}), 3.15$ (dd, $J=11.49,7.96 \mathrm{~Hz}, 1 \mathrm{H}), 6.97$ - 7.12 (m, $1 \mathrm{H}), 7.20$ (ddd, $J=10.23,9.22,2.78 \mathrm{~Hz}, 1 \mathrm{H}), 9.59$ (br. s., $1 \mathrm{H})$. LCMS C ${ }_{10} \mathrm{H}_{10} \mathrm{~F}_{2} \mathrm{~N}_{2} \mathrm{O}(\mathrm{m} / \mathrm{z}): 213\left(\mathrm{M}+\mathrm{H}^{+}\right),>99 \%$ purity. 
To a mechanically stirred solution of 3-amino-7,9-difluoro-4,5-dihydro-1H-benzo[b]azepin2(3H)-one $(28.4 \mathrm{~g}, 134 \mathrm{mmol})$ in $\mathrm{iPrOH}(1.25 \mathrm{~L})$ at $70^{\circ} \mathrm{C}$ was added 2-hydroxy-5nitrobenzaldehyde $(0.671 \mathrm{~g}, 4.02 \mathrm{mmol})$. Within $1 \mathrm{~min}$, a thick precipitate formed. LPyroglutamic acid $(17.28 \mathrm{~g}, 134 \mathrm{mmol})$ was added, the reaction mixture turned bright yellow, and was stirred at $70{ }^{\circ} \mathrm{C}$ for 5 days. The reaction was cooled to $\sim 50{ }^{\circ} \mathrm{C}$ and the solid filtered off and washed twice with $\mathrm{PrOH}$. The solid was suspended in hexanes, stirred, filtered and dried to give $37.97 \mathrm{~g}$ of (S)-3-amino-7,9-difluoro-4,5-dihydro-1H-benzo[b]azepin-2(3H)-one L-pyroglutamate salt as an off-white solid. Chiral HPLC analysis using a Chiralpak IC analytical column $(150 \mathrm{~mm}, 4.6 \mathrm{~mm}, 5 \mathrm{u})$ eluting with $60: 40 \mathrm{EtOH} / \mathrm{hexanes}$ (plus 0.1\% diethylamine as modifier) as the mobile phase for $15 \mathrm{~min}$. at $1 \mathrm{~mL} / \mathrm{min}$. provided good separation of a racemic standard. The $\mathrm{R}$ enantiomer eluted at $5.54 \mathrm{~min}$. and the $\mathrm{S}$ enantiomer eluted at $6.32 \mathrm{~min}$. This indicated that the chiral purity of the $\mathrm{S}$ enantiomer was $94.7 \%$ ee. This was suspended in 9:1 ACN:water $(600 \mathrm{~mL})$ and heated at $70^{\circ} \mathrm{C}$ for $18 \mathrm{~h}$. The suspension was cooled to $\sim 40^{\circ} \mathrm{C}$, filtered, washed with $\mathrm{CAN}$ and dried to give $35.8 \mathrm{~g}$ of the salt as a white solid. Chiral HPLC analysis by the same method indicated that the chiral purity of the S enantiomer was $>99 \%$ ee, with none of the $\mathrm{R}$ enantiomer detected. The salt was stirred vigorously in a mixture of conc. $\mathrm{NH}_{4} \mathrm{OH}(15 \mathrm{~mL})$ in water $(200 \mathrm{~mL})$ for $7 \mathrm{~min}$. The solid was filtered, resuspended in a mixture of conc. $\mathrm{NH}_{4} \mathrm{OH}(15 \mathrm{~mL})$ in water $(200 \mathrm{~mL})$ for $7 \mathrm{~min}$ and filtered again. The solid was stirred in water $(200 \mathrm{~mL})$ for $15 \mathrm{~min}$, filtered and dried to give (S)-3-amino-7,9-difluoro-4,5-dihydro-1H-benzo[b]azepin-2(3H)-one as a white solid (20 g, $70 \%$ yield). ${ }^{1} \mathrm{H}$ NMR (400 MHz, DMSO- $\left.d_{6}\right) \delta$ ppm 1.68 - $1.84(\mathrm{~m}, 1 \mathrm{H}), 2.15-2.36(\mathrm{~m}, 1 \mathrm{H})$, 2.57 - 2.81 (m, $2 \mathrm{H}), 3.15$ (dd, $J=11.62,7.83 \mathrm{~Hz}, 1 \mathrm{H}), 7.07$ (dd, $J=8.84,1.52 \mathrm{~Hz}, 1 \mathrm{H}), 7.13$ 7.33 (m, $1 \mathrm{H}), 9.59$ (br. s., $1 \mathrm{H})$. LCMS C ${ }_{10} \mathrm{H}_{10} \mathrm{~F}_{2} \mathrm{~N}_{2} \mathrm{O}(\mathrm{m} / \mathrm{z}): 213\left(\mathrm{M}+\mathrm{H}^{+}\right),>99 \%$ purity.

To a mixture of (S)-3-amino-7,9-difluoro-4,5-dihydro-1H-benzo[b]azepin-2(3H)-one (19.1 g, $90 \mathrm{mmol})$, 5-benzyl-4H-1,2,4-triazole-3-carboxylic acid hydrochloride (22.65 g, $95 \mathrm{mmol})$ and DIEA (47.2 mL, $270 \mathrm{mmol})$ in DCM $(650 \mathrm{~mL})$ cooled in an ice/water bath was added 2,4,6tripropyl-1,3,5,2,4,6-trioxatriphosphinane 2,4,6-trioxide (T3P, 50\% by wt. in ethyl acetate) (81 $\mathrm{mL}, 135 \mathrm{mmol}$ ) dropwise over $13 \mathrm{~min}$. The reaction was stirred at $\mathrm{rt}$ for $45 \mathrm{~min}$ becoming homogeneous after $10 \mathrm{~min}$. The reaction was diluted with $0.5 \mathrm{M} \mathrm{HCl}(600 \mathrm{~mL})$ and a solid precipitated from the organic phase. The 2 layers were separated, the organics, including the solid, were treated with satd. $\mathrm{NaHCO}_{3}$ solution and the 2 phases shaken vigorously. The 2 layers were separated and the solid filtered off and washed with DCM. The solid was stirred in water $(600 \mathrm{~mL})$ for $60 \mathrm{~min}$, filtered, and washed with water, and dried in vacuum oven at $50^{\circ} \mathrm{C}$ to give $33.1 \mathrm{~g}$ of product. The solid was resuspended in water $(700 \mathrm{~mL})$ and stirred for $2 \mathrm{~h}$. The solid was filtered, washed with water, and dried in vacuum oven at $50^{\circ} \mathrm{C}$ to give (S)-5-benzyl-N-(7,9-difluoro-2-oxo-2,3,4,5-tetrahydro-1H-benzo[b]azepin-3-yl)-4H-1,2,4-

triazole-3-carboxamide (6) as a white solid (32 g, 88\% yield). ${ }^{1} \mathrm{H}$ NMR (400 MHz, DMSO- $d_{6}$ ) $\delta$ ppm 2.26 (br. s., $1 \mathrm{H}), 2.35$ - 2.48 (m, $1 \mathrm{H}), 2.67$ - 2.89 (m, $2 \mathrm{H}), 4.12$ (br. s., $2 \mathrm{H}$ ), 4.34 (dt, $J=11.43,7.93 \mathrm{~Hz}, 1 \mathrm{H}), 7.15$ (d, $J=8.84 \mathrm{~Hz}, 1 \mathrm{H}), 7.19$ - 7.47 (m, $6 \mathrm{H}), 8.22$ (br. s., $1 \mathrm{H}), 9.96$ (s, $1 \mathrm{H}), 14.31$ (br. s., $1 \mathrm{H})$. LCMS $\mathrm{C}_{20} \mathrm{H}_{17} \mathrm{~F}_{2} \mathrm{~N}_{5} \mathrm{O}_{2}(\mathrm{~m} / \mathrm{z}): 313\left(\mathrm{M}+\mathrm{Na}^{+}\right), 398\left(\mathrm{M}+\mathrm{H}^{+}\right),>99 \%$ purity. Chiral HPLC analysis using a ChromegaChiral ${ }^{\text {TM }} \mathrm{CC} 4$ analytical column $(150 \mathrm{~mm}, 4.6$ mm, $5 \mathrm{u}$ ) eluting with $\mathrm{CH}_{3} \mathrm{CN}$ (plus $0.2 \%$ formic acid and $0.1 \%$ diethylamine as modifiers) as the mobile phase for $30 \mathrm{~min}$. at $1 \mathrm{~mL} / \mathrm{min}$. provided good separation of a racemic standard. The $\mathrm{R}$ enantiomer eluted at $4.57 \mathrm{~min}$. and the $\mathrm{S}$ enantiomer (6) eluted at $5.96 \mathrm{~min}$. This indicated that the chiral purity of 6 prepared by this method was $>99.9 \%$ ee, with none of the $\mathrm{R}$ enantiomer detected. Anal. Calcd for $\mathrm{C}_{20} \mathrm{H}_{17} \mathrm{~F}_{2} \mathrm{~N}_{5} \mathrm{O}_{2} \mathrm{C}, 60.43 ; \mathrm{H}, 4.31 ; \mathrm{N}, 17.63$. Found: $\mathrm{C}$, $60.33 ; \mathrm{H}, 4.03 ; \mathrm{N}, 17.00$. 
(S)-5-Benzyl-N-(4-oxo-2,3,4,5-tetrahydrobenzo[b][1,4]oxazepin-3-yl)-4H-1,2,4-triazole3-carboxamide (8). To a mixture of (S)-3-amino-2,3-dihydrobenzo[b][1,4]-oxazepin-4(5H)one hydrochloride (1.024 g, $4.77 \mathrm{mmol})$ and 5-benzyl-4H-1,2,4-triazole-3-carboxylic acid hydrochloride (1.2 g, $5.0 \mathrm{mmol})$ in DCM $(30 \mathrm{~mL})$ was added DIPEA $(9.5 \mathrm{~mL}, 54.6 \mathrm{mmol})$ and the resulting solution stirred at $\mathrm{rt}$ for 1 hour. $\mathrm{T}_{3} \mathrm{P}$ solution $(50 \%$ by wt. in EtOAc, $4.27 \mathrm{~mL}, 7.16$ $\mathrm{mmol}$ ) was added and the reaction stirred at $\mathrm{rt}$ for a further 1 hour. Additional $\mathrm{T}_{3} \mathrm{P}$ solution (1 $\mathrm{mL}, 1.68 \mathrm{mmol})$ and DIEA $(1 \mathrm{~mL}, 5.74 \mathrm{mmol})$ were added and the reaction stirred at $\mathrm{rt}$ for a further 1 hour. The reaction was concentrated on a rotavapor to remove DCM, then redissolved in EtOAc and washed with $1 \mathrm{M} \mathrm{HCl}$, satd. $\mathrm{NaHCO}_{3}$, water and brine. The organic layer was concentrated to a foam which was redissolved in EtOAc $(10 \mathrm{~mL})$ and stirred at $\mathrm{rt}$ for 3 days to give a thick paste. Added more EtOAc $(15 \mathrm{~mL})$ and stirred vigorously for $10 \mathrm{~min}$. The resulting solid was filtered off and washed with EtOAc. The filtrate was concentrated and purified by silica gel chromatography (24 g silica column; 10-65\% EtOAc/hexanes). The filtered solid and the purified fractions from chromatography were combined and dried to give $(S)$-5-benzyl-N(4-oxo-2,3,4,5-tetrahydrobenzo[b][1,4] oxazepin-3-yl)-4H-1,2,4-triazole-3-carboxamide (8) as an off-white solid (0.905 g, 52\% yield). ${ }^{1} \mathrm{H}$ NMR (400 MHz, DMSO- $\left.d_{6}\right) \delta$ ppm $4.05-4.20$ (m, $2 \mathrm{H}), 4.43$ (dd, $J=10.52,6.46 \mathrm{~Hz}, 1 \mathrm{H}), 4.52$ (t, $J=10.52 \mathrm{~Hz}, 1 \mathrm{H}), 4.80$ (dt, $J=10.65,7.22 \mathrm{~Hz}$, $1 \mathrm{H}), 7.04$ - 7.19 (m, $4 \mathrm{H}), 7.19$ - 7.45 (m, $7 \mathrm{H}), 8.55$ (br. s., $1 \mathrm{H}), 10.12$ - 10.25 (m, $1 \mathrm{H})$. LCMS $\mathrm{C}_{19} \mathrm{H}_{17} \mathrm{~N}_{5} \mathrm{O}_{3}(\mathrm{~m} / \mathrm{z}): 364\left(\mathrm{M}+\mathrm{H}^{+}\right),>99 \%$ purity.

(S)-5-Benzyl-N-(1-methyl-2-oxo-2,3,4,5-tetrahydro-1H-benzo[b]azepin-3-yl)-4H-1,2,4triazole-3-carboxamide (9). To (S)-tert-butyl (2-oxo-2,3,4,5-tetrahydro-1H-benzo[b]azepin3-yl)carbamate (300 mg, $1.09 \mathrm{mmol})$ dissolved in DMF (4 mL) was added MeI (0.081 mL, 1.3 $\mathrm{mmol})$. Potassium carbonate $(210 \mathrm{mg}, 1.52 \mathrm{mmol})$ was then added portion wise. After stirring for 2 days at $\mathrm{rt}$, the reaction was quenched with water $(20 \mathrm{~mL})$ and stirred for $15 \mathrm{~min}$. The resulting solid was filtered off, washed with water and dried to afford (S)-tert-butyl (1-methyl2-oxo-2,3,4,5-tetrahydro-1H-benzo[b]azepin-3-yl)carbamate (246 mg, $78 \%$ yield). ${ }^{1} \mathrm{H}$ NMR (400 MHz, DMSO-d $\left.d_{6}\right) \delta$ ppm $1.33(\mathrm{~s}, 9 \mathrm{H}), 1.91$ - $2.20(\mathrm{~m}, 2 \mathrm{H}), 2.57$ - $2.72(\mathrm{~m}, 2 \mathrm{H}), 3.27$ (s, $3 \mathrm{H}), 3.86$ (dt, $J=11.68,8.31 \mathrm{~Hz}, 1 \mathrm{H}), 7.02(\mathrm{~d}, J=8.59 \mathrm{~Hz}, 1 \mathrm{H}), 7.15$ - 7.25 (m, $1 \mathrm{H}), 7.29$ (d, $J=7.07 \mathrm{~Hz}, 1 \mathrm{H}), 7.32$ - $7.42(\mathrm{~m}, 2 \mathrm{H})$. LCMS C $16 \mathrm{H}_{22} \mathrm{~N}_{2} \mathrm{O}_{3}(\mathrm{~m} / \mathrm{z}): 313\left(\mathrm{M}+\mathrm{Na}^{+}\right), 291\left(\mathrm{M}+\mathrm{H}^{+}\right)$, $>99 \%$ purity.

To a solution of (S)-tert-butyl (1-methyl-2-oxo-2,3,4,5-tetrahydro-1H-benzo[b]azepin-3yl)carbamate $(240 \mathrm{mg}, 0.83 \mathrm{mmol})$ in DCM $(5 \mathrm{~mL})$ was added $4 \mathrm{~N} \mathrm{HCl}$ in dioxane $(0.827 \mathrm{ml}$, $3.31 \mathrm{mmol})$ and the reaction stirred at $\mathrm{rt}$ for $3 \mathrm{~h}$. Additional $4 \mathrm{~N} \mathrm{HCl}$ was added $(0.205 \mathrm{~mL}, 0.83$ $\mathrm{mmol}$ ). And stirring continued for $24 \mathrm{~h}$. The reaction was concentrated to afford (S)-3-amino1-methyl-4,5-dihydro-1H-benzo[b]azepin-2(3H)-one hydrochloride $(270 \mathrm{mg}, 144 \%$ yield) which was used directly in the next step. ${ }^{1} \mathrm{H}$ NMR (400 MHz, DMSO- $\left.d_{6}\right) \delta$ ppm $2.07-2.18$ $(\mathrm{m}, 1 \mathrm{H}), 2.36$ - $2.49(\mathrm{~m}, 1 \mathrm{H}), 2.64-2.85(\mathrm{~m}, 2 \mathrm{H}), 3.28$ - $3.35(\mathrm{~s}, 3 \mathrm{H}), 3.59$ - $3.73(\mathrm{~m}, 1 \mathrm{H})$, 7.21 - 7.32 (m, $1 \mathrm{H}), 7.33$ - 7.39 (m, $1 \mathrm{H}), 7.39$ - 7.45 (m, $2 \mathrm{H}), 8.28$ (br. s., $3 \mathrm{H})$. LCMS $\mathrm{C}_{11} \mathrm{H}_{14} \mathrm{~N}_{2} \mathrm{O}(\mathrm{m} / \mathrm{z}): 191\left(\mathrm{M}+\mathrm{H}^{+}\right), 96 \%$ purity.

To a solution of (S)-3-amino-1-methyl-4,5-dihydro-1H-benzo[b]azepin-2(3H)-one hydrochloride (270 mg, $1.2 \mathrm{mmol}$ ), 5-benzyl-4H-1,2,4-triazole-3-carboxylic acid (290 mg, $1.43 \mathrm{mmol})$ and DIPEA $(0.832 \mathrm{~mL}, 4.76 \mathrm{mmol})$ in DCM $(6.5 \mathrm{~mL})$ was added $\mathrm{T}_{3} \mathrm{P}$ solution (50\% by wt. in EtOAc, $1.2 \mathrm{~mL}, 2.03 \mathrm{mmol})$. The reaction was stirred at $\mathrm{rt}$ for $90 \mathrm{~min}$. and then quenched with EtOAc and water. The aqueous layer was separated and extracted with further with EtOAc and the combined organic extracts were purified via silica gel chromatography eluting with 5-60\% (EtOH/EtOAc 3:1)/heptane. The desired fractions were concentrated to afford (S)-5-benzyl-N-(1-methyl-2-oxo-2,3,4,5-tetrahydro-1H-benzo[b]azepin-3-yl)-4H1,2,4-triazole-3-carboxamide (9) (33 mg, 7 \% yield). ${ }^{1} \mathrm{H}$ NMR (400 MHz, $\mathrm{CDCl}_{3}$ ) $\delta$ ppm 1.97 
- $2.17(\mathrm{~m}, 1 \mathrm{H}), 2.57$ - $2.82(\mathrm{~m}, 2 \mathrm{H}), 2.82$ - $3.01(\mathrm{~m}, 1 \mathrm{H}), 3.44$ (s, $3 \mathrm{H}), 4.21$ (s, $2 \mathrm{H}), 4.64$ (dt, $J=11.12,7.58 \mathrm{~Hz}, 1 \mathrm{H}), 7.18-7.27(\mathrm{~m}, 3 \mathrm{H}) 7.30-7.38(\mathrm{~m}, 6 \mathrm{H}), 8.19$ (d, J=7.83 Hz, $1 \mathrm{H})$. LCMS $\mathrm{C}_{21} \mathrm{H}_{21} \mathrm{~N}_{5} \mathrm{O}_{2}(\mathrm{~m} / \mathrm{z}): 376\left(\mathrm{M}+\mathrm{H}^{+}\right),>99 \%$ purity.

(S)-5-Benzyl-N-(2-oxo-2,3,4,5-tetrahydro-1H-benzo[b]azepin-3-yl)-4H-1,2,4-triazole-3carboxamide (10). To a suspension of (S)-3-amino-4,5-dihydro-1H-benzo[b]azepin-2(3H)one (1.0 g, $5.67 \mathrm{mmol})$ and 5-benzyl-4H-1,2,4-triazole-3-carboxylic acid hydrochloride (1.5 g, $6.24 \mathrm{mmol})$ in DCM $(48.5 \mathrm{~mL})$ at $0^{\circ} \mathrm{C}$ was added DIPEA $(3.47 \mathrm{~mL}, 19.9 \mathrm{mmol})$. After stirring for $30 \mathrm{~min}$ at $0{ }^{\circ} \mathrm{C}, \mathrm{T}_{3} \mathrm{P}$ solution $(50 \%$ by wt. in EtOAc, $4.74 \mathrm{~mL}, 7.94 \mathrm{mmol})$ was slowly added. After stirring for $20 \mathrm{~min}$ at $0{ }^{\circ} \mathrm{C}$, the reaction solution was warmed up to rt. After $5 \mathrm{~h}$, additional DIPEA $(0.5 \mathrm{~mL})$ and $\mathrm{T}_{3} \mathrm{P}$ solution $(0.5 \mathrm{~mL})$ were added and the reaction stirred overnight at rt. The resultant solid was collected by filtration and washed with DCM and dried to give product ( $464 \mathrm{mg}, 22 \%$ yield) as a white solid. The filtrate was concentrated and stirred in water to precipitate a white solid. The solid was collected and washed with water and $\mathrm{Et}_{2} \mathrm{O}$ and dried to give additional product (1.22 g, $59 \%$ yield). Combining products gave (S)-5benzyl-N-(2-oxo-2,3,4,5-tetrahydro-1H-benzo[b]azepin-3-yl)-4H-1,2,4-triazole-3-

carboxamide (10) (1.68 g, $81 \%$ yield). ${ }^{1} \mathrm{H}$ NMR (400 MHz, DMSO- $\left.d_{6}\right) \delta$ ppm 2.23 (d, $J=9.09$ $\mathrm{Hz}, 1 \mathrm{H}), 2.34$ - $2.49(\mathrm{~m}, 1 \mathrm{H}), 2.63-2.89(\mathrm{~m}, 2 \mathrm{H}), 4.11$ (s, $2 \mathrm{H}), 4.33$ (dt, J=11.62, $7.83 \mathrm{~Hz}$, $1 \mathrm{H}), 7.04$ (d, J=7.83 Hz, $1 \mathrm{H}), 7.09-7.20$ (m, $1 \mathrm{H}), 7.20$ - 7.40 (m, $7 \mathrm{H}), 8.28$ (br. s., $1 \mathrm{H})$, 10.01 (s, $1 \mathrm{H}), 14.41$ (br. s., $1 \mathrm{H})$. LCMS C ${ }_{20} \mathrm{H}_{19} \mathrm{~N}_{5} \mathrm{O}_{2}(\mathrm{~m} / \mathrm{z}): 362\left(\mathrm{M}+\mathrm{H}^{+}\right),>99 \%$ purity.

(S)-5-Benzyl-N-(7,9-difluoro-1-methyl-2-oxo-2,3,4,5-tetrahydro-1H-benzo[b]azepin-3yl)-4H-1,2,4-triazole-3-carboxamide (11). To a solution of (S)-3-amino-7,9-difluoro-4,5dihydro-1H-benzo[b]azepin-2 $(3 \mathrm{H})$-one $(1.1 \mathrm{~g}, 5.18 \mathrm{mmol})$ and TEA (1.084 mL, $7.78 \mathrm{mmol})$ in DCM $(10 \mathrm{~mL})$ stirred under $\mathrm{N}_{2}$ at $20^{\circ} \mathrm{C}$ was added $\mathrm{Boc}_{2} \mathrm{O}(1.32 \mathrm{~mL}, 5.70 \mathrm{mmol})$ dropwise over $5 \mathrm{~min}$. The reaction mixture was stirred at $\mathrm{rt}$ for $2 \mathrm{~h}$ and then diluted with DCM $(30 \mathrm{~mL})$ and this was washed with water $(4 \mathrm{x} 10 \mathrm{~mL})$, the organic phase was separated and washed with brine, dried over $\mathrm{Na}_{2} \mathrm{SO}_{4}$, filtered and concentrated to afford (S)-tert-butyl (S)-tert-butyl (7,9difluoro-2-oxo-2,3,4,5-tetrahydro-1H-benzo[b]azepin-3-yl)carbamate (1.6 g, $98 \%$ yield) as a cream colored solid. ${ }^{1} \mathrm{H}$ NMR $\left(400 \mathrm{MHz}, \mathrm{DMSO}-d_{6}\right) \delta \mathrm{ppm} 1.35$ (s, $\left.9 \mathrm{H}\right), 2.02-2.30(\mathrm{~m}, 2$ $\mathrm{H}), 2.62$ - $2.83(\mathrm{~m}, 2 \mathrm{H}), 3.83-3.91(\mathrm{~m}, 1 \mathrm{H}), 7.02-7.07$ (m, $2 \mathrm{H}), 7.22$ - $7.36(\mathrm{~m}, 1 \mathrm{H}), 9.63$ (s, $1 \mathrm{H})$. LCMS $\mathrm{C}_{19} \mathrm{H}_{26} \mathrm{~F}_{2} \mathrm{~N}_{2} \mathrm{O}_{3}(\mathrm{~m} / \mathrm{z}): 213\left([\mathrm{M}-\mathrm{BOC}]+\mathrm{H}^{+}\right), 99 \%$ purity.

To a mixture of cesium carbonate $(2.337 \mathrm{~g}, 7.17 \mathrm{mmol})$ and (S)-tert-butyl (7,9-difluoro-2-oxo2,3,4,5-tetrahydro-1H-benzo[b]azepin-3-yl)carbamate (1.6 g, $5.12 \mathrm{mmol})$ in DMF (25 $\mathrm{mL})$ was added iodomethane $(0.384 \mathrm{~mL}, 6.15 \mathrm{mmol})$. The reaction was stirred at room temperature for $25 \mathrm{~min}$. and then quenched with water $(25 \mathrm{~mL})$ and stirred vigorously for a further $5 \mathrm{~min}$. The resulting solid was filtered off, rinsed with water and then hexane and dried to give (S)tert-butyl (7,9-difluoro-1-methyl-2-oxo-2,3,4,5-tetrahydro-1H-benzo[b]azepin-3yl)carbamate (1.6 g, 93\% yield). ${ }^{1} \mathrm{H}$ NMR (400 MHz, DMSO- $\left.d_{6}\right) \delta$ ppm $1.30(\mathrm{~s}, 9 \mathrm{H}), 1.95$ $2.20(\mathrm{~m}, 2 \mathrm{H}), 2.60-2.80(\mathrm{~m}, 2 \mathrm{H}), 3.20(\mathrm{~s}, 3 \mathrm{H}), 3.81-3.90(\mathrm{~m}, 1 \mathrm{H}), 7.13-7.20(\mathrm{~m}, 2 \mathrm{H}), 7.28$ - $7.41(\mathrm{~m}, 1 \mathrm{H})$. LCMS C $16 \mathrm{H}_{20} \mathrm{~F}_{2} \mathrm{~N}_{2} \mathrm{O}_{3}(\mathrm{~m} / \mathrm{z}): 227$ ([M-BOC]+ $\mathrm{H}^{+}$), 97\% purity.

To a solution of (S)-tert-butyl (7,9-difluoro-1-methyl-2-oxo-2,3,4,5-tetrahydro$1 \mathrm{Hbenzo}[\mathrm{b}]$ azepin-3-yl)carbamate $(1.6 \mathrm{~g}, 4.9 \mathrm{mmol})$ in DCM $(5 \mathrm{~mL})$ stirred at $0{ }^{\circ} \mathrm{C}$ was added $4 \mathrm{M} \mathrm{HCl}$ in 1,4-dioxane $(2.45 \mathrm{~mL}, 9.81 \mathrm{mmol})$ and the reaction stirred at $\mathrm{rt}$ for $2 \mathrm{~h}$. The reaction mixture was concentrated under the reduced pressure and the solid obtained was triturated in $\mathrm{Et}_{2} \mathrm{O}$ and dried to obtain (S)-3-amino-7,9-difluoro-1-methyl-4,5-dihydro-1H-benzo[b]azepin$2(3 \mathrm{H})$-one hydrochloride (1.3 g, $99 \%$ yield) as an off white solid. ${ }^{1} \mathrm{H}$ NMR (400 MHz, DMSO$\left.d_{6}\right) \delta$ ppm $2.02-2.20(\mathrm{~m}, 1 \mathrm{H}), 2.30-2.48(\mathrm{~m}, 1 \mathrm{H}), 2.74-2.85(\mathrm{~m}, 2 \mathrm{H}), 3.24(\mathrm{~s}, 3 \mathrm{H}), 3.81$ - 
3.89 (m, $1 \mathrm{H}), 7.18-7.22(\mathrm{~m}, 1 \mathrm{H}), 7.38-7.42$ (m, $1 \mathrm{H}), 8.40$ (br. s., $3 \mathrm{H}$ ). LCMS C ${ }_{11} \mathrm{H}_{13} \mathrm{ClF}_{2} \mathrm{~N}_{2} \mathrm{O}$ $(\mathrm{m} / \mathrm{z}): 227\left(\left[\mathrm{M}+\mathrm{H}^{+}\right), 98 \%\right.$ purity.

A mixture of (S)-3-amino-7,9-difluoro-1-methyl-4,5-dihydro-1H-benzo[b]azepin-2(3H)-one hydrochloride $(0.04 \mathrm{~g}, \quad 0.152 \mathrm{mmol}), \quad$-benzyl-4H-1,2,4-triazole-3-carboxylic acid hydrochloride $(0.038 \mathrm{~g}, 0.16 \mathrm{mmol})$ and DIPEA $(0.093 \mathrm{~mL}, 0.533 \mathrm{mmol})$ in DCM $(2 \mathrm{~mL})$ was stirred vigorously for $5 \mathrm{~min}$. A solution of $\mathrm{T}_{3} \mathrm{P}(50 \%$ by wt. in EtOAc, $0.127 \mathrm{~mL}, 0.213 \mathrm{mmol})$ was added and the reaction stirred at $\mathrm{rt}$ for $10 \mathrm{~min}$. The reaction was diluted with EtOAc and washed with $1 \mathrm{M} \mathrm{HCl}$ solution, satd $\mathrm{NaHCO}_{3}$ followed by brine. The organic phase was concentrated to a give a solid which was suspended in hexanes, filtered and dried to give (S)5-benzyl-N-(7,9-difluoro-1-methyl-2-oxo-2,3,4,5-tetrahydro-1H-benzo[b]azepin-3-yl)-4H1,2,4-triazole-3-carboxamide (11) (41 mg, $64 \%$ yield) as a white solid. ${ }^{1} \mathrm{H}$ NMR (DMSO-d6) $\delta 2.16-2.37(\mathrm{~m}, 2 \mathrm{H}), 2.70-2.82,(\mathrm{~m}, 2 \mathrm{H}), 4.11(\mathrm{~s}, 2 \mathrm{H}), 3.20(\mathrm{~s}, 3 \mathrm{H}), 4.35(\mathrm{dt}, \mathrm{J}=10.9,8.0$ $\mathrm{Hz}, 1 \mathrm{H}), 7.14$ - 7.42 (m, 7H), 8.33 (br. m., $1 \mathrm{H}$ ), 14.52 (br. s., $1 \mathrm{H}$ ). LCMS $\mathrm{C}_{21} \mathrm{H}_{19} \mathrm{~F}_{2} \mathrm{~N}_{5} \mathrm{O}_{2}(\mathrm{~m} / \mathrm{z}$ ): $412\left(\mathrm{M}+\mathrm{H}^{+}\right),>99 \%$ purity.

\section{RIP1 (1-375) preparation}

The human RIP1 gene [receptor (TNFRSF)-interacting serine-threonine kinase 1] was cloned from human adrenal gland cDNA. Primers were designed from the reference sequence NM_003804.3 using the 5' Kozak-adapted gene-specific primer and the $3^{\prime}$ gene-specific primer. PCR products were cloned into the pENTR/TEV/D-TOPO vector. The Gateway LR reaction was performed with a pDEST8HisGSTTev vector to produce the final clone: pDEST8HisGSTTev human RIPK1 1375 . Baculovirus was generated using the bac to bac system (Invitrogen) according to manufacturer's specifications. pDEST8HisGSTTev human RIPK1 1375 baculovirus infected insect cells (BIICs) were prepared during baculovirus generation according to [Wasilko and Lee, 2006]. RIP1 protein was purified by capture on Glutathione Agarose (Pierce) and eluted with 20 $\mathrm{mM}$ reduced glutathione. The protein was then run on a size exclusion column (Superdex200, GE Healthcare) to separate the aggregated protein from the active dimeric protein and to exchange the protein into assay compatible buffer $(25 \mathrm{mM}$ Tris, pH7.5, $150 \mathrm{mM} \mathrm{NaCl}, 1 \mathrm{mM}$ DTT, 5\% Glycerol). The human RIP1 crystallography construct was Flag.1-294, C34A, C127A, C233A, C240A. Similar protocols were used to generate the the orthologs; mouse RIP 1(1-378), rat RIP1(1-377), rabbit RIP1 (1-371), dog RIP1 (1-373), minipig RIP1 (1-375), and monkey RIP1 (1$379)$.

\section{In vitro assays}

ADP-Glo Activity Assay. The catalytic activity of RIP1 was quantified utilizing the Promega ADP-Glo kinase kit as previously described (Harris et al, 2016) using either a four-parameter curve fit or a tight binding curve fit for compounds whose potency was less than the detection limit of the assay ( $\sim$ half the enzyme concentration). Data are presented as the mean $\mathrm{IC}_{50}$ from at least $\mathrm{n}=2$ determinations.

U937 and 2929 Cell Necroptosis Assays. The efficacy of RIP1 inhibitors were determined in vitro using human monocytic leukemia U937 cells or mouse L-cells NCTC 929 (L929) cells in a necroptosis assay as previously described (Harris et al, 2016).

Biological in Vitro Whole Blood Assay. Compound 6 was evaluated in human and cynomolgus monkey whole blood assays. For the assay, 3 stock solutions each of $200 \mathrm{ng} / \mathrm{mL}$ TNF (Cell 
Sciences), $400 \mu \mathrm{M}$ QVD-Oph or zVAD.fmk (R\&D Systems) and $20 \mu \mathrm{M}$ SMAC mimetic 2',2"'(2,4-hexadiyne-1,6-diyl)bis[1-[[(2S)-1-(N-methyl-L-alanyl-L-threonyl)-2-pyrrolidinyl]methyl]5-(phenylthio)-1H-tetrazole (RMT 5265, Li et al, 2004) were prepared in phenol red free RPMI 1640 medium supplemented with $1 \%$ fetal bovine serum, 100 units $/ \mathrm{mL}$ penicillin and $100 \mu \mathrm{g} / \mathrm{mL}$ streptomycin. In addition, 5-fold dilution series of compound $\mathbf{6}$ were prepared in the same medium supplemented with $1 \% \mathrm{DMSO}$, with top concentrations of $1 \mu \mathrm{M}$ and $5 \mu \mathrm{M}$ for human and monkey assays, respectively. A $5 \mathrm{uL}$ solution of compound $\mathbf{6}$ at each dilution was transferred to a 96 well tissue culture treated assay plate and $5 \mathrm{uL}$ of each of the 3 stock solutions was added. Whole blood was collected by venous puncture in heparin tubes (Griener Bio-One). Whole blood ( $80 \mu \mathrm{L})$ was added to each well of the assay plate, mixed briefly and incubated for $6 \mathrm{~h}$ at $37{ }^{\circ} \mathrm{C}, 5 \% \mathrm{CO}_{2}$. Following incubation, PBS $(200 \mu \mathrm{L})$ was added to each well and the assay plate was centrifuged at $1700 \mathrm{rpm}$ for $5 \mathrm{~min}$. Supernatants were frozen at $-70^{\circ} \mathrm{C}$. Concentrations of MIP-1 $\beta$ (human) and IL-1 $\beta$ (monkey) were determined by sandwich ELISA (Meso Scale Discovery) following the manufacturer's instructions.

Neutrophil Necroptotic Assay. Compound 6 was evaluated in human neutrophils isolated from whole blood using standard method involving dextran sedimentation and Ficoll-Hypaque density gradient centrifugation. Necroptotic cell death was induced in freshly isolated neutrophils with 10 ng/ml TNF $\alpha, 50 \mu \mathrm{M}$ QVD-Oph and $100 \mathrm{nM}$ SMAC mimetic 2',2'"-(2,4-hexadiyne-1,6-diyl)bis[1[[(2S)-1-(N-methyl-L-alanyl-L-threonyl)-2-pyrrolidinyl]methyl]-5-(phenylthio)-1H-tetrazole (SMAC mimetic RMT 5265, Li et al, 2004). Induced cell death was evaluated $21 \mathrm{~h}$ post stimulation by measuring cellular ATP levels and LDH release into media. Intracellular ATP levels were quantified using CellTiter-Glo Luminescent Cell Viability assay (Promega). Lactate dehydrogenase (LDH) release into media was evaluated using a Cytotoxicity Detection kit [LDH] (Roche Applied Sciences). Concentration of MIP-1 $\beta$ in cell-free supernatants was determined by sandwich ELISA (Meso Scale Discovery) following the manufacturer's instructions.

\section{Mode of inhibition of Compound 6}

To determine the mode of inhibition of Compound 6 on hRIP1 (1-375), the effect of substrate concentration on the $\mathrm{IC}_{50}$ was determined using an ADP-Glo assay measuring the activity of RIP1 by quantifying the conversion of ATP to ADP due to both enzyme catalyzed autophosphorylation and ATPase activities. Test compound was prepared in assay buffer (50 mM Hepes $\mathrm{pH} 7.5,50$ $\mathrm{mM} \mathrm{NaCl}, 30 \mathrm{mM} \mathrm{MgCl} 2,1 \mathrm{mM}$ DTT, $0.02 \%$ CHAPS, $0.5 \mathrm{mg} / \mathrm{mL}$ BSA) and serially diluted 1:1.5 in a 22 point titration (high final concentration $3 \mu \mathrm{M}$ ) and added to a 384 white low volume Greiner plate. $3.5 \mu \mathrm{L}$ of each inhibitor concentration and $3.5 \mu \mathrm{L}$ of $25 \mathrm{nM}$ enzyme (final) in assay buffer were added to the plate. Following these additions, $3.5 \mu \mathrm{L}$ of ATP (15.6 $\mu \mathrm{M}$ to $875 \mu \mathrm{M}$ final) in assay buffer was added to the plate to initiate the reaction. The reaction progressed for $5 \mathrm{~h}$ at room temperature. Following this reaction $5 \mu \mathrm{L}$ of Promega ADP-Glo Reagent with $0.02 \%$ CHAPS was added to each well and incubated for $1 \mathrm{~h}$ at room temperature. This quenched the kinase reaction and depleted any remaining ATP. $5 \mu \mathrm{L}$ of Promega ADP-Glo Detection solution with $0.02 \%$ CHAPS was then added to each well and incubated at room temperature for $30 \mathrm{~min}$. This converted ADP to ATP and introduced luciferase and luciferin to detect ATP, allowing for the quantification of the ADP produced by RIP1. The luminescence was then measured on a Perkin Elmer ViewLux . Luminescence data was normalized to the high and low controls for each ATP concentration and expressed as fractional activity remaining. The $\mathrm{IC}_{50}$ at each $\mathrm{ATP}$ concentration was determined using the Morrison tight binding equation (eq 1). $\mathrm{IC}_{50}$ values were then plotted as a function of substrate concentration (S) using the competitive inhibition equation (eq 2) where $\mathrm{K}_{\mathrm{i}}$ 
is the inhibition constant and $\mathrm{K}_{\mathrm{m}}$ is the Michaelis constant for S [Williams and Morrison, 1979].

$$
\begin{aligned}
& \frac{v_{i}}{v_{o}}=\frac{-\left([I]-[E]+a p p K_{\mathrm{i}}\right)+\sqrt{\left([I]-[E]+a p p K_{\mathrm{i}}\right)^{2}+4[\mathrm{E}] * a p p K_{\mathrm{i}}}}{2[\mathrm{E}]} \\
& \mathrm{IC}_{50}=\mathrm{K}_{\mathrm{i}}^{*}\left(1+\left(\mathrm{S} / \mathrm{K}_{\mathrm{m}}\right)\right)
\end{aligned}
$$

Figure S1. Compound 6 demonstrates characteristics of a tight binding ATP competitive inhibitor of human RIP1 with a $\mathbf{K}_{\mathbf{i}}$ of $1.5 \mathrm{nM}$. The correlation between $\mathrm{IC}_{50}$ and $\mathrm{ATP}$ concentrations fits a mutually competitive model with $\mathrm{IC}_{50}$ values increasing linearly with increasing substrate concentrations. Due to the potency of the compound and limitations on ATP concentrations tolerated by the detection system, small changes in $\mathrm{IC}_{50}$ were expected. Data points are shown as the average of $n=2$ to $n=4$ determinations with error bars from the standard deviations. The fitted line is from eq 2 with $\mathrm{K}_{\mathrm{i}}=1.5 \pm 0.5 \mathrm{nM}$ and $\mathrm{K}_{\mathrm{m}}=140 \pm 54 \mu \mathrm{M}$. The $\mathrm{K}_{\mathrm{i}}$ agrees well with the $\mathrm{IC}_{50}$ value reported in the main text.

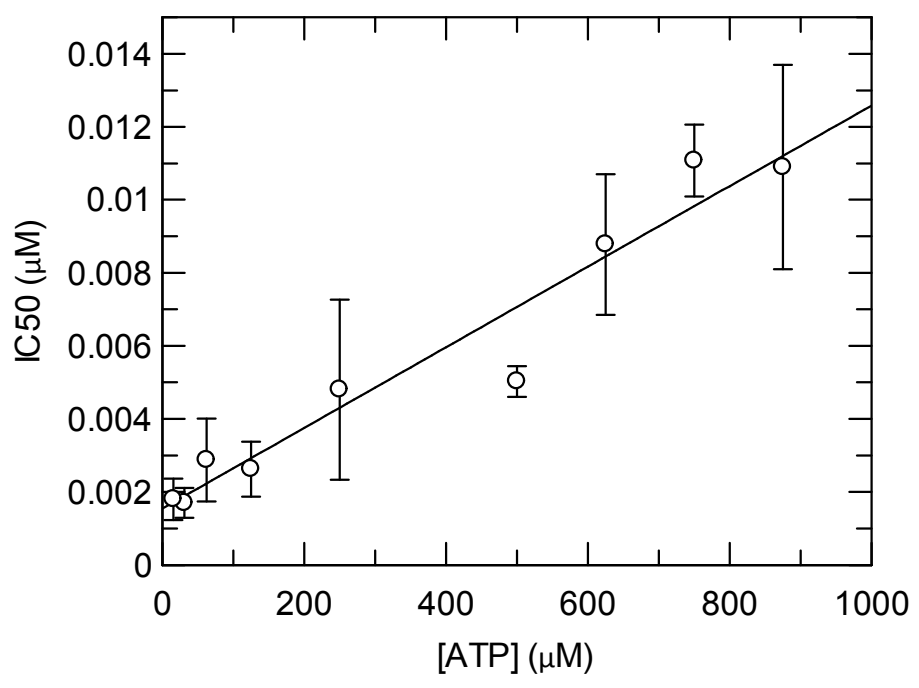

\section{Compound 6 binding kinetics}

To determine the off rate constant for Compound $\mathbf{6}$, a fluorescence polarization (FP) competitive binding assay was used. This assay utilizes a reversible fluorescent ligand ((14- $(2-\{[3-(\{2-\{[4-$ (cyanomethyl)phenyl]amino\}-6-[(5-cyclopropyl-1H-pyrazol-3-yl)amino]-4-

pyrimidinyl\}amino)propyl]amino - - 2-oxoethyl)-16,16,18,18-tetramethyl-6,7,7a,8a,9,10,16,18-

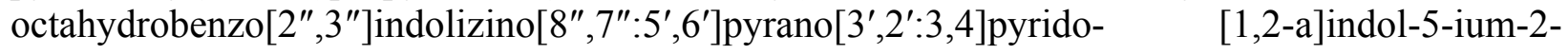
sulfonate) that is competitive with ATP. In a typical experiment, $3.5 \mu \mathrm{L}$ of titrated inhibitor in buffer (50 mM Hepes pH7.5, $10 \mathrm{mM} \mathrm{NaCl}, 50 \mathrm{mM} \mathrm{MgCl} 2,0.5 \mathrm{mM}$ DTT, and 0.02\% CHAPS) and $3.5 \mu \mathrm{L}$ of ligand in buffer were added to a 384 black low volume Greiner plate. Then $3.5 \mu \mathrm{L}$ of enzyme was added to the plate to initiate the reaction and the plate was immediately monitored kinetically for 50 minutes using an Analyst GT plate reader (excitation $530 \mathrm{~nm}$; emission $580 \mathrm{~nm}$; $561 \mathrm{~nm}$ dichroic), with the shortest time interval possible between reads to maximize data density. The final concentrations of enzyme and fluorescent ligand were $10 \mathrm{nM}$ and $5 \mathrm{nM}$, respectively. The FP data was converted to the concentration of enzyme-ligand complex (EL) formed (eq 3 ) and measuring controls for the polarization of free $\left(\mathrm{P}_{\mathrm{f}}\right)$ and bound $\left(\mathrm{P}_{\mathrm{b}}\right)$ ligand, where $\mathrm{P}=$ observed polarization and $\mathrm{g}=\mathrm{g}$ factor [Jameson and Mocz, 2005]. The resulting individual binding curves 
obtained at each inhibitor concentration were fitted globally using KinTek Explorer to a competitive model which describes both ligand binding and inhibitor binding equilibria $(\mathrm{E}+\mathrm{L} \Leftrightarrow$ $\mathrm{EL}$ and $\mathrm{E}+\mathrm{I} \Leftrightarrow \mathrm{EI}$ ), where $\mathrm{E}=$ enzyme, $\mathrm{L}=$ ligand, $\mathrm{EL}=$ enzyme ligand complex, $\mathrm{I}=$ inhibitor, $\mathrm{EI}=$ enzyme inhibitor complex, $\mathrm{k}_{1}=$ association rate of ligand, $\mathrm{k}_{2}=$ dissociation rate of ligand, $\mathrm{k}_{3}$ $=$ association rate of inhibitor, and $\mathrm{k}_{4}=$ dissociation rate of inhibitor. Multiple iterations of fitting were utilized until rates converged on a global minimum.

$$
\begin{aligned}
& {[E L]=L^{*} \frac{\left(3-\mathrm{P}_{\mathrm{b}}\right)\left(\mathrm{P}-\mathrm{P}_{\mathrm{f}}\right)}{(3-\mathrm{P})\left(\mathrm{P}_{\mathrm{b}}-\mathrm{P}_{\mathrm{f}}\right)+(\mathrm{g}-1)\left(3-\mathrm{P}_{\mathrm{f}}\right)\left(\mathrm{P}_{\mathrm{b}}-\mathrm{P}\right)}} \\
& \mathrm{E}+\mathrm{L} \underset{\mathrm{k}_{2}}{\stackrel{\mathrm{k}_{1}}{\rightleftarrows}} \mathrm{EL} \\
& E+1 \quad \stackrel{k_{3}}{\underset{k_{4}}{\rightleftarrows}} \text { El }
\end{aligned}
$$

Figure S2. Compound 6 is a slowly dissociating inhibitor of $h R I P 1\left(k_{\text {off }}=0.000117 \mathrm{sec}^{-1}\right)$, demonstrating distinctive biphasic kinetics in an FP competitive binding assay. The other parameters from the average of $\mathrm{n}=2$ global fits were $\mathrm{k}_{1}=0.0526 \mathrm{nM}^{-1} \mathrm{~s}^{-1}, \mathrm{k}_{2}=0.00265 \mathrm{~s}^{-1}$, and $\mathrm{k}_{3}$ $=0.00210 \mathrm{nM}^{-1} \mathrm{~s}^{-1} . \mathrm{k}_{3}$ for Compound $\mathbf{6}$ is poorly defined in this experiment due to insufficient data density for accurate measurement of rapid inhibitor association. Stopped-flow tryptophan fluorescence was used for accurate measurement of $\mathrm{k}_{\mathrm{on}}$ as described below.

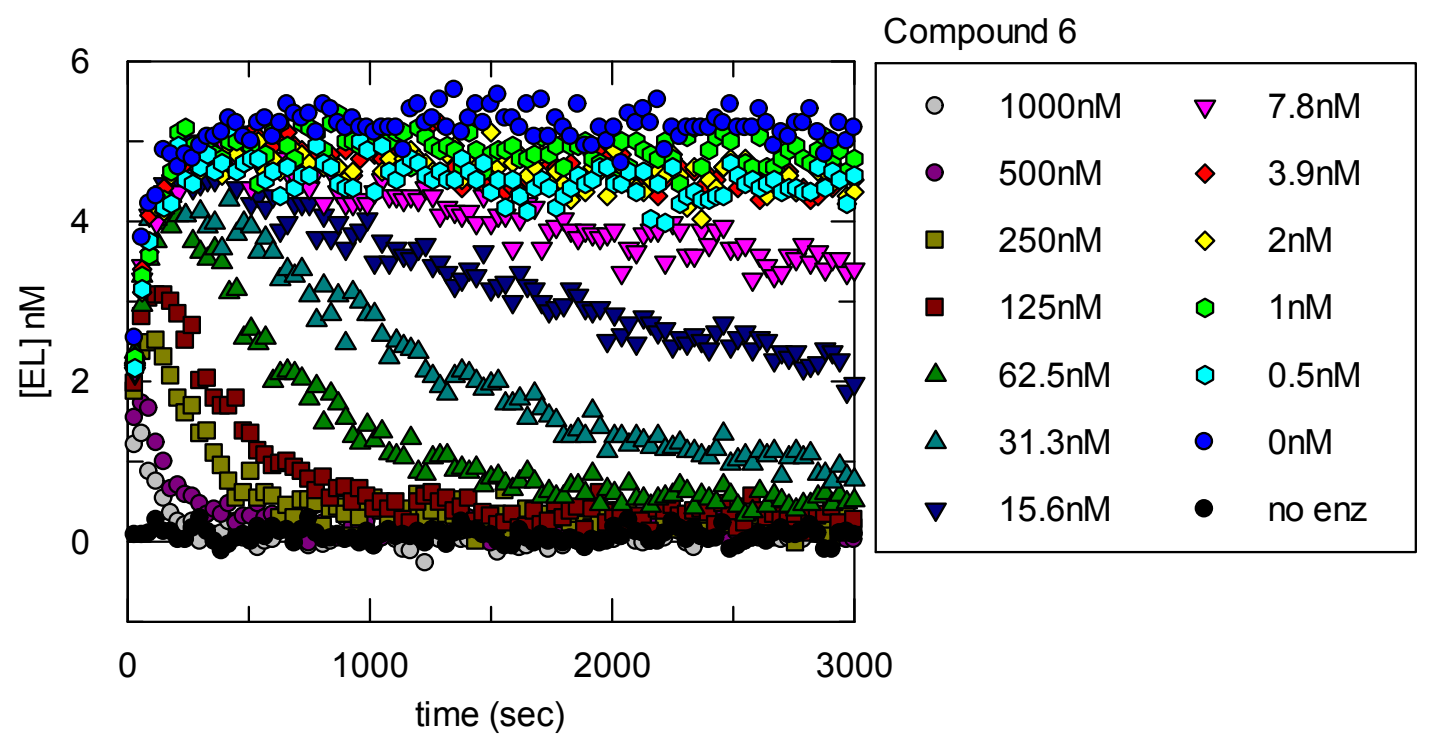

To determine the on rate constant of Compound $\mathbf{6}$ accurately, changes in the intrinsic tryptophan fluorescence of hRIP1 were measured upon inhibitor binding. Compound 6 was titrated ( 0.625 to $5 \mu \mathrm{M}$ final) at $2 \mathrm{x}$ in buffer (50 mM Hepes $\mathrm{pH} 7.5,10 \mathrm{mM} \mathrm{NaCl}, 50 \mathrm{mM} \mathrm{MgCl} 2,0.5 \mathrm{mM}$ DTT, $0.02 \%$ CHAPS) with $1 \%$ DMSO. $250 \mathrm{nM}$ (final) hRIP1 (1-375) was prepared in buffer at $2 \mathrm{x}$. Inhibitor and enzyme were rapidly mixed using an Applied Photophysics SX20 stopped-flow spectrometer (fluorescence mode, $10 \mathrm{~mm}$ pathlength flow cell orientation, excitation $285 \mathrm{~nm}$, emission $>320 \mathrm{~nm}$, bandpass filter). PM voltage was set to approximately $80 \%$ of auto PM determined after mixing equal volumes of RIP1 and buffer. After determining this baseline, enzyme and inhibitor were rapidly mixed and 10,000 data time points were collected for up to 200 seconds for each inhibitor concentration, starting with the lowest inhibitor concentration. 
Decreased fluorescence upon compound 6 binding was observed. Progress curves were averaged $(n=3$ to $n=4)$ and fitted to a single exponential plus a slope to determine the $k_{\text {obs }}$ at each inhibitor concentration. $\mathrm{k}_{\mathrm{obs}}$ was then plotted as a function of inhibitor concentration and increased linearly with increasing inhibitor concentrations suggesting simple one-step binding mechanisms in the concentration range studied. The slope of the linear fit is equal to the on rate constant for Compound 6.

Figure S3. Compound 6 quenches intrinsic Trp fluorescence in the stopped-flow spectrometer consistent with a single step binding mechanism with an on rate constant of $\mathbf{0 . 0 2 5} \mu \mathbf{M}^{-1} \mathbf{s}^{-1}$. The top figure below shows representative stopped-flow time courses for different concentrations of compound $\mathbf{6}$ with hRIP1. Data were fitted to a single exponential decay with a linear slope (solid lines): $\mathrm{Y}=\mathrm{A} *\left(\exp \left(-\mathrm{k}_{\mathrm{obs}}{ }^{*} \mathrm{t}\right)+\mathrm{b} * \mathrm{t}+\mathrm{C}\right.$. The slope portion of the fit is due to photobleaching of the enzyme and is also observed in control experiments in the absence of inhibitor. The average $\mathrm{k}_{\mathrm{obs}}$ values and their standard errors from 3 to 4 determinations are replotted versus inhibitor concentration in the lower figure to obtain the on rate constant from the slope $\left(0.025 \pm 0.007 \mu \mathrm{M}^{-1} \mathrm{~s}^{-1}\right)$ of the linear fit (correlation coefficient = 0.9992). Intercepts of the replot $\left(\mathrm{k}_{\text {off }}\right)$ are poorly defined $\left(0.00053 \pm 0.0020 \mathrm{~s}^{-1}\right)$ due to extreme extrapolation from the $\mathrm{K}_{\mathrm{i}}(\sim 3,000$ $* \mathrm{~K}_{\mathrm{i}}$ at $5 \mu \mathrm{M}$ ). Therefore, $\mathrm{k}_{\text {off }}$ was measured using the FP competition assay (see above). The calculated $\mathrm{K}_{\mathrm{i}}$ from the measured $\mathrm{k}_{\text {off }}$ and $\mathrm{k}_{\text {on }}$ values $\left(\mathrm{K}_{\mathrm{i}}=\mathrm{k}_{\mathrm{off}} / \mathrm{k}_{\mathrm{on}}\right)$ is $4.7 \mathrm{nM}$, which is good agreement with the $\mathrm{K}_{\mathrm{i}}$ from the ATP substrate competition experiment.

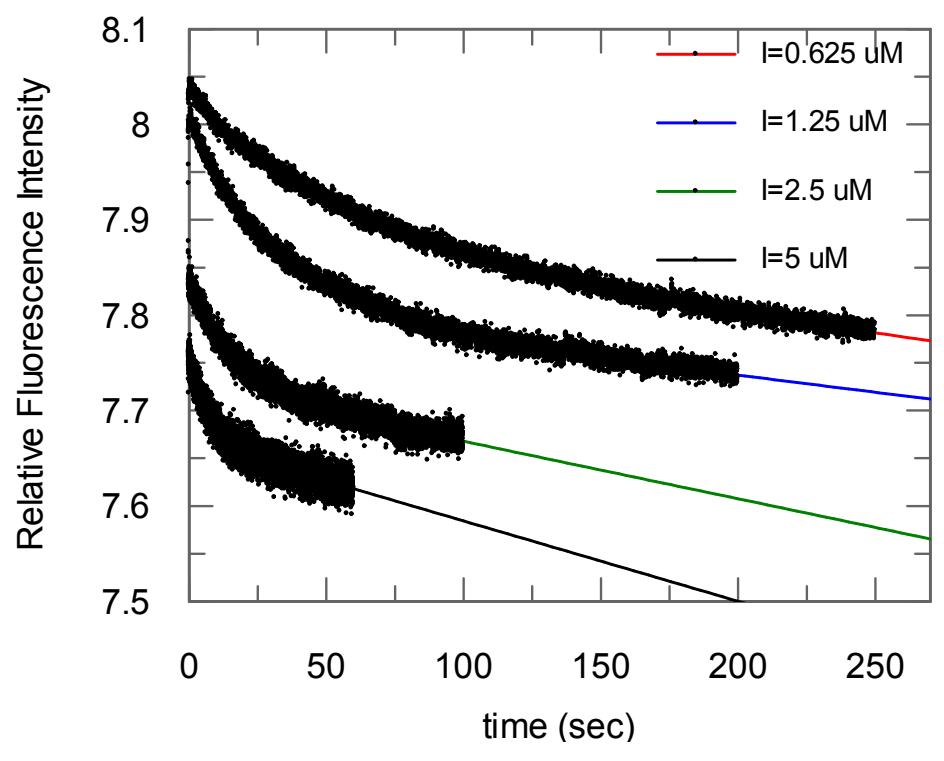




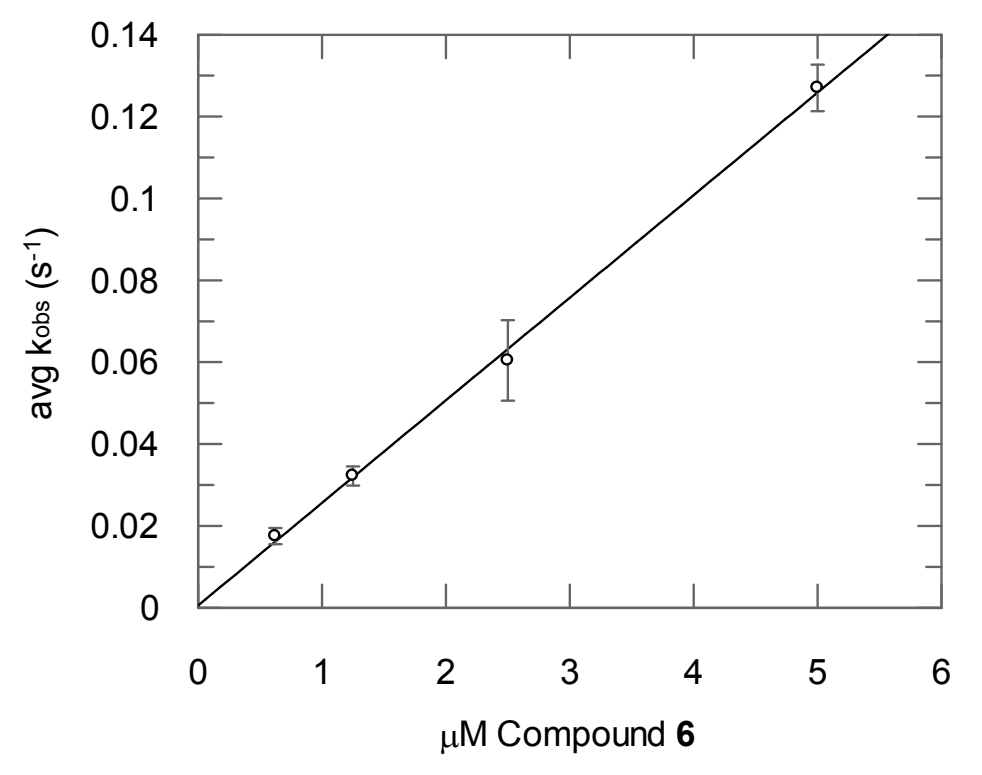




\section{Compound 6 kinase selectivity and species selectivity profiles}

\section{Percent Enzyme Inhibition against Reaction Biology Corporation (RBC) kinase Panel}

Compound 6 was tested at $10 \mu \mathrm{M}$ in duplicate against 359 kinases in the Reaction Biology Corporation (RBC) kinase panel. Control compound was tested in 10-dose $\mathrm{IC}_{50}$ mode with 3-fold serial dilution starting at $20 \mu \mathrm{M}$. Reactions were carried out at $10 \mu \mathrm{M}$ ATP. Full protocol details are available at http://www.reactionbiology.com. Data is reported as \% enzyme activity (relative to DMSO controls) in Table S1. Activity $<50 \%$ (average of $\mathrm{n}=2$ ) was observed for ABL1, ABL2/ARG, BLK, c-Src, DDR2, EPHA5, EPHB2, FGR, FRK/PTK5, FYN, LYN, LYN B, PEAK1 and YES/YES1. However full curve analysis for these 14 kinases against compound $\mathbf{6}$ at a top concentration of $30 \mu \mathrm{M}$ (see Table S2) found no inhibition indicating the initial single concentration findings were false positives. The kinase panel did not include RIP1.

Table S1. RBC kinase panel for compound 6.

\begin{tabular}{|c|c|c|c|c|c|c|}
\hline RBC Kinase: & $\begin{array}{c}\text { Cpd 6 } \\
\% \text { enzyme } \\
\text { activity }\end{array}$ & $\begin{array}{c}\text { Cpd 6 } \\
\text { \% enzyme } \\
\text { activity }\end{array}$ & $\begin{array}{c}\text { Cpd } 6 \\
\text { Average \% } \\
\text { enzyme } \\
\text { activity }\end{array}$ & $\begin{array}{c}\mathrm{IC}_{50}(\mathrm{M}) \\
\text { Staurosporine }\end{array}$ & $\begin{array}{c}\text { IC }_{50}(\mathrm{M}) \\
\text { Alternate } \\
\text { Control } \\
\text { cpd }\end{array}$ & $\begin{array}{l}\text { Alternate } \\
\text { compound ID }\end{array}$ \\
\hline ABL1 & 6.77 & 6.20 & 6.49 & $5.20 \mathrm{E}-08$ & & \\
\hline ABL2/ARG & 2.66 & 1.98 & 2.32 & $1.70 \mathrm{E}-08$ & & \\
\hline ACK1 & 91.64 & 90.81 & 91.23 & $3.44 \mathrm{E}-08$ & & \\
\hline AKT1 & 87.09 & 87.06 & 87.08 & $3.97 \mathrm{E}-09$ & & \\
\hline AKT2 & 80.42 & 78.39 & 79.40 & $1.40 \mathrm{E}-08$ & & \\
\hline AKT3 & 115.12 & 110.12 & 112.62 & $3.92 \mathrm{E}-09$ & & \\
\hline ALK & 96.74 & 96.03 & 96.39 & $1.91 \mathrm{E}-09$ & & \\
\hline ALK1/ACVRL1 & 79.12 & 77.54 & 78.33 & ND & $7.30 \mathrm{E}-09$ & LDN193189 \\
\hline ALK2/ACVR1 & 101.76 & 97.57 & 99.67 & ND & $1.06 \mathrm{E}-07$ & LDN193189 \\
\hline ALK3/BMPR1A & 95.61 & 95.25 & 95.43 & ND & $1.80 \mathrm{E}-08$ & LDN193189 \\
\hline ALK4/ACVR1B & 104.11 & 102.81 & 103.46 & ND & $3.95 \mathrm{E}-07$ & LDN193189 \\
\hline ALK5/TGFBR1 & 97.00 & 96.12 & 96.56 & ND & $3.73 \mathrm{E}-07$ & LDN193189 \\
\hline ALK6/BMPR1B & 97.00 & 96.84 & 96.92 & ND & $8.73 \mathrm{E}-09$ & LDN193189 \\
\hline ARAF & 93.91 & 91.18 & 92.55 & ND & $1.74 \mathrm{E}-08$ & GW5074 \\
\hline ARK5/NUAK1 & 84.06 & 82.84 & 83.45 & $1.03 \mathrm{E}-09$ & & \\
\hline ASK1/MAP3K5 & 99.55 & 98.59 & 99.07 & $1.52 \mathrm{E}-08$ & & \\
\hline Aurora A & 96.25 & 90.41 & 93.33 & $1.23 \mathrm{E}-09$ & & \\
\hline Aurora B & 90.54 & 89.44 & 89.99 & $8.43 \mathrm{E}-09$ & & \\
\hline Aurora C & 103.29 & 100.76 & 102.02 & $2.59 \mathrm{E}-09$ & & \\
\hline $\mathrm{AXL}$ & 101.33 & 97.94 & 99.64 & $1.45 \mathrm{E}-08$ & & \\
\hline BLK & 37.56 & 36.30 & 36.93 & $1.76 \mathrm{E}-09$ & & \\
\hline BMPR2 & 114.18 & 110.70 & 112.44 & $3.82 \mathrm{E}-07$ & & \\
\hline BMX/ETK & 91.08 & 89.97 & 90.52 & $9.60 \mathrm{E}-09$ & & \\
\hline BRAF & 96.93 & 96.90 & 96.91 & ND & $2.40 \mathrm{E}-08$ & GW5074 \\
\hline BRK & 95.77 & 95.33 & 95.55 & $3.92 \mathrm{E}-07$ & & \\
\hline BRSK1 & 99.91 & 99.08 & 99.50 & $1.16 \mathrm{E}-09$ & & \\
\hline BRSK2 & 96.20 & 96.18 & 96.19 & $3.09 \mathrm{E}-09$ & & \\
\hline BTK & 58.55 & 58.53 & 58.54 & $1.48 \mathrm{E}-08$ & & \\
\hline c-Kit & 87.39 & 82.06 & 84.72 & $9.13 \mathrm{E}-08$ & & \\
\hline c-MER & 94.84 & 93.66 & 94.25 & $1.03 \mathrm{E}-08$ & & \\
\hline c-MET & 87.14 & 86.23 & 86.69 & $1.49 \mathrm{E}-07$ & & \\
\hline c-Src & 2.15 & 1.91 & 2.03 & $2.71 \mathrm{E}-09$ & & \\
\hline CAMK1a & 94.63 & 93.64 & 94.13 & 2.04E-09 & & \\
\hline
\end{tabular}




\begin{tabular}{|c|c|c|c|c|c|c|}
\hline CAMK1b & 93.25 & 88.96 & 91.10 & 4.36E-09 & & \\
\hline CAMK1d & 95.85 & 95.23 & 95.54 & $3.25 \mathrm{E}-10$ & & \\
\hline CAMK1g & 96.61 & 95.87 & 96.24 & 8.92E-09 & & \\
\hline CAMK2a & 97.99 & 97.43 & 97.71 & $<7.63 \mathrm{E}-11$ & & \\
\hline CAMK2b & 96.32 & 95.35 & 95.84 & $1.09 \mathrm{E}-10$ & & \\
\hline CAMK2d & 103.56 & 102.81 & 103.18 & $<7.63 \mathrm{E}-11$ & & \\
\hline CAMK2g & 97.11 & 95.46 & 96.29 & $4.50 \mathrm{E}-10$ & & \\
\hline CAMK4 & 95.72 & 94.55 & 95.14 & $2.17 \mathrm{E}-07$ & & \\
\hline CAMKK1 & 102.26 & 99.14 & 100.70 & $5.12 \mathrm{E}-08$ & & \\
\hline CAMKK2 & 87.11 & 87.10 & 87.10 & 7.94E-08 & & \\
\hline CDC7/DBF4 & 105.23 & 104.87 & 105.05 & $1.75 \mathrm{E}-08$ & & \\
\hline CDK1/cyclin A & 96.06 & 95.11 & 95.59 & $3.25 \mathrm{E}-09$ & & \\
\hline CDK1/cyclin B & 93.94 & 92.83 & 93.38 & $2.40 \mathrm{E}-09$ & & \\
\hline CDK1/cyclin E & 95.96 & 95.50 & 95.73 & $3.90 \mathrm{E}-09$ & & \\
\hline CDK16/cyclin Y (PCTAIRE) & 96.33 & 95.36 & 95.85 & $1.21 \mathrm{E}-08$ & & \\
\hline CDK2/cyclin A & 77.94 & 77.79 & 77.86 & $8.69 \mathrm{E}-10$ & & \\
\hline CDK2/Cyclin A1 & 90.13 & 89.11 & 89.62 & $2.03 \mathrm{E}-09$ & & \\
\hline CDK2/cyclin E & 88.79 & 88.75 & 88.77 & $1.97 \mathrm{E}-09$ & & \\
\hline CDK3/cyclin E & 87.06 & 86.34 & 86.70 & $1.56 \mathrm{E}-08$ & & \\
\hline CDK4/cyclin D1 & 97.97 & 97.88 & 97.92 & $1.92 \mathrm{E}-08$ & & \\
\hline CDK4/cyclin D3 & 91.73 & 89.31 & 90.52 & $3.46 \mathrm{E}-08$ & & \\
\hline CDK5/p25 & 72.38 & 70.42 & 71.40 & $3.32 \mathrm{E}-09$ & & \\
\hline CDK5/p35 & 71.11 & 70.78 & 70.95 & $1.87 \mathrm{E}-09$ & & \\
\hline CDK6/cyclin D1 & 96.81 & 95.26 & 96.04 & $5.51 \mathrm{E}-09$ & & \\
\hline CDK6/cyclin D3 & 99.65 & 99.02 & 99.33 & $6.39 \mathrm{E}-08$ & & \\
\hline CDK7/cyclin H & 109.10 & 108.38 & 108.74 & $2.95 \mathrm{E}-06$ & & \\
\hline CDK9/cyclin K & 99.55 & 97.49 & 98.52 & $1.51 \mathrm{E}-07$ & & \\
\hline CDK9/cyclin T1 & 98.66 & 98.54 & 98.60 & $1.32 \mathrm{E}-08$ & & \\
\hline CHK1 & 96.75 & 96.12 & 96.43 & $1.33 \mathrm{E}-10$ & & \\
\hline CHK2 & 102.74 & 101.65 & 102.19 & $8.90 \mathrm{E}-09$ & & \\
\hline CK1a1 & 92.67 & 92.43 & 92.55 & 4.05E-06 & & \\
\hline CK1d & 86.78 & 86.25 & 86.51 & ND & $1.81 \mathrm{E}-07$ & D4476 \\
\hline CK1epsilon & 103.81 & 103.81 & 103.81 & ND & $2.51 \mathrm{E}-07$ & D4476 \\
\hline CK1g1 & 88.16 & 87.30 & 87.73 & $5.20 \mathrm{E}-06$ & & \\
\hline CK1g2 & 102.21 & 101.26 & 101.74 & $1.45 \mathrm{E}-06$ & & \\
\hline CK1g3 & 104.51 & 103.19 & 103.85 & $2.92 \mathrm{E}-06$ & & \\
\hline CK2a & 120.74 & 118.67 & 119.71 & ND & $9.19 \mathrm{E}-08$ & GW5074 \\
\hline CK2a2 & 70.76 & 67.19 & 68.98 & $3.78 \mathrm{E}-07$ & & \\
\hline CLK1 & 97.07 & 96.74 & 96.90 & $1.42 \mathrm{E}-08$ & & \\
\hline CLK2 & 76.32 & 72.29 & 74.31 & $5.21 \mathrm{E}-09$ & & \\
\hline CLK3 & 97.80 & 97.10 & 97.45 & $2.24 \mathrm{E}-06$ & & \\
\hline CLK4 & 91.83 & 87.35 & 89.59 & 5.38E-08 & & \\
\hline COT1/MAP3K8 & 98.66 & 97.48 & 98.07 & ND & $8.25 \mathrm{E}-06$ & Ro-31-8220 \\
\hline CSK & 66.48 & 66.39 & 66.43 & $1.67 \mathrm{E}-08$ & & \\
\hline CTK/MATK & 97.58 & 97.08 & 97.33 & 7.64E-07 & & \\
\hline DAPK1 & 101.95 & 100.21 & 101.08 & 8.80E-09 & & \\
\hline DAPK2 & 98.98 & 98.74 & 98.86 & 8.33E-09 & & \\
\hline DCAMKL1 & 93.82 & 93.65 & 93.74 & $5.02 \mathrm{E}-07$ & & \\
\hline DCAMKL2 & 95.15 & 95.03 & 95.09 & $7.96 \mathrm{E}-08$ & & \\
\hline DDR1 & 97.18 & 96.12 & 96.65 & 4.66E-09 & & \\
\hline DDR2 & 42.56 & 39.43 & 40.99 & $2.97 \mathrm{E}-10$ & & \\
\hline DLK/MAP3K12 & 86.36 & 85.32 & 85.84 & $1.08 \mathrm{E}-08$ & & \\
\hline DMPK & 109.01 & 108.60 & 108.81 & $1.08 \mathrm{E}-07$ & & \\
\hline DMPK2 & 97.32 & 96.19 & 96.75 & $9.99 \mathrm{E}-10$ & & \\
\hline DRAK1/STK17A & 94.60 & 94.47 & 94.53 & $1.52 \mathrm{E}-08$ & & \\
\hline
\end{tabular}




\begin{tabular}{|c|c|c|c|c|c|c|}
\hline DYRK1/DYRK1A & 95.83 & 95.53 & 95.68 & $3.88 \mathrm{E}-09$ & & \\
\hline DYRK1B & 94.25 & 92.81 & 93.53 & $9.89 \mathrm{E}-10$ & & \\
\hline DYRK2 & 113.90 & 102.05 & 107.98 & $2.29 \mathrm{E}-07$ & & \\
\hline DYRK3 & 104.84 & 103.52 & 104.18 & $3.22 \mathrm{E}-08$ & & \\
\hline DYRK4 & 94.55 & 93.07 & 93.81 & ND & $2.41 \mathrm{E}-06$ & GW5074 \\
\hline EGFR & 103.89 & 101.58 & 102.74 & $1.31 \mathrm{E}-07$ & & \\
\hline EPHA1 & 95.74 & 95.49 & 95.62 & $1.59 \mathrm{E}-07$ & & \\
\hline EPHA2 & 88.30 & 85.42 & 86.86 & $4.94 \mathrm{E}-08$ & & \\
\hline EPHA3 & 96.98 & 95.60 & 96.29 & $4.47 \mathrm{E}-08$ & & \\
\hline EPHA4 & 78.45 & 77.84 & 78.15 & $1.94 \mathrm{E}-08$ & & \\
\hline EPHA5 & 34.25 & 34.19 & 34.22 & $2.14 \mathrm{E}-08$ & & \\
\hline EPHA6 & 93.79 & 92.47 & 93.13 & $1.80 \mathrm{E}-08$ & & \\
\hline EPHA7 & 102.02 & 99.67 & 100.85 & $4.22 \mathrm{E}-08$ & & \\
\hline EPHA8 & 97.87 & 94.67 & 96.27 & $1.21 \mathrm{E}-07$ & & \\
\hline EPHB1 & 57.22 & 57.17 & 57.20 & $3.67 \mathrm{E}-08$ & & \\
\hline EPHB2 & 29.79 & 29.04 & 29.42 & $1.13 \mathrm{E}-07$ & & \\
\hline EPHB3 & 84.00 & 82.17 & 83.09 & $1.26 \mathrm{E}-06$ & & \\
\hline EPHB4 & 83.35 & 82.60 & 82.98 & $2.15 \mathrm{E}-07$ & & \\
\hline ERBB2/HER2 & 96.84 & 96.54 & 96.69 & $1.67 \mathrm{E}-07$ & & \\
\hline ERBB4/HER4 & 94.38 & 93.16 & 93.77 & $2.48 \mathrm{E}-07$ & & \\
\hline ERK1 & 98.69 & 98.08 & 98.39 & $2.22 \mathrm{E}-05$ & & \\
\hline ERK2/MAPK1 & 93.84 & 92.41 & 93.12 & $1.40 \mathrm{E}-05$ & & \\
\hline ERK5/MAPK7 & 98.97 & 97.08 & 98.02 & $1.64 \mathrm{E}-05$ & & \\
\hline ERK7/MAPK15 & 102.85 & 97.48 & 100.16 & $1.04 \mathrm{E}-08$ & & \\
\hline FAK/PTK2 & 91.46 & 91.22 & 91.34 & $1.42 \mathrm{E}-08$ & & \\
\hline FER & 87.13 & 84.85 & 85.99 & $3.83 \mathrm{E}-10$ & & \\
\hline FES/FPS & 93.66 & 92.20 & 92.93 & $2.57 \mathrm{E}-09$ & & \\
\hline FGFR1 & 97.67 & 95.89 & 96.78 & 7.63E-09 & & \\
\hline FGFR2 & 95.53 & 93.73 & 94.63 & $2.40 \mathrm{E}-09$ & & \\
\hline FGFR3 & 100.72 & 97.77 & 99.24 & $1.94 \mathrm{E}-08$ & & \\
\hline FGFR4 & 90.19 & 89.43 & 89.81 & $1.88 \mathrm{E}-07$ & & \\
\hline FGR & 6.11 & 5.54 & 5.83 & $1.07 \mathrm{E}-09$ & & \\
\hline FLT1/VEGFR1 & 96.55 & 95.29 & 95.92 & $9.77 \mathrm{E}-09$ & & \\
\hline FLT3 & 92.34 & 91.87 & 92.10 & $1.75 \mathrm{E}-09$ & & \\
\hline FLT4/VEGFR3 & 94.76 & 93.61 & 94.19 & $3.34 \mathrm{E}-09$ & & \\
\hline FMS & 96.86 & 95.35 & 96.10 & $2.76 \mathrm{E}-09$ & & \\
\hline FRK/PTK5 & 46.41 & 46.19 & 46.30 & $1.90 \mathrm{E}-08$ & & \\
\hline FYN & 5.09 & 4.18 & 4.63 & $1.64 \mathrm{E}-09$ & & \\
\hline GCK/MAP4K2 & 96.08 & 95.50 & 95.79 & $5.30 \mathrm{E}-10$ & & \\
\hline GLK/MAP4K3 & 93.85 & 92.56 & 93.20 & $1.68 \mathrm{E}-10$ & & \\
\hline GRK1 & 105.64 & 105.37 & 105.50 & $6.88 \mathrm{E}-08$ & & \\
\hline GRK2 & 101.50 & 100.40 & 100.95 & $1.41 \mathrm{E}-06$ & & \\
\hline GRK3 & 98.05 & 97.68 & 97.86 & $9.75 \mathrm{E}-07$ & & \\
\hline GRK4 & 100.83 & 98.85 & 99.84 & $9.74 \mathrm{E}-08$ & & \\
\hline GRK5 & 104.05 & 103.32 & 103.69 & $8.90 \mathrm{E}-08$ & & \\
\hline GRK6 & 97.75 & 91.33 & 94.54 & 4.32E-08 & & \\
\hline GRK7 & 101.47 & 99.04 & 100.26 & $5.51 \mathrm{E}-09$ & & \\
\hline GSK3a & 99.34 & 97.33 & 98.33 & $6.54 \mathrm{E}-09$ & & \\
\hline GSK3b & 102.29 & 100.84 & 101.57 & $5.14 \mathrm{E}-09$ & & \\
\hline Haspin & 98.69 & 95.61 & 97.15 & $2.58 \mathrm{E}-08$ & & \\
\hline $\mathrm{HCK}$ & 84.35 & 83.94 & 84.15 & $2.06 \mathrm{E}-09$ & & \\
\hline HGK/MAP4K4 & 93.86 & 92.82 & 93.34 & $5.58 \mathrm{E}-10$ & & \\
\hline HIPK1 & 110.64 & 107.89 & 109.27 & ND & $2.36 \mathrm{E}-07$ & Ro-31-8220 \\
\hline HIPK2 & 96.52 & 95.26 & 95.89 & $5.95 \mathrm{E}-07$ & & \\
\hline HIPK3 & 102.38 & 102.11 & 102.25 & $1.08 \mathrm{E}-06$ & & \\
\hline
\end{tabular}




\begin{tabular}{|c|c|c|c|c|c|c|}
\hline HIPK4 & 98.85 & 98.04 & 98.45 & $3.93 \mathrm{E}-07$ & & \\
\hline HPK1/MAP4K1 & 94.41 & 94.05 & 94.23 & ND & $2.42 \mathrm{E}-08$ & Ro-31-8220 \\
\hline IGF1R & 96.54 & 96.38 & 96.46 & $5.76 \mathrm{E}-08$ & & \\
\hline IKKa/CHUK & 109.12 & 107.50 & 108.31 & $1.30 \mathrm{E}-07$ & & \\
\hline $\mathrm{IKKb} / \mathrm{IKBKB}$ & 106.03 & 103.84 & 104.93 & $5.45 \mathrm{E}-07$ & & \\
\hline IKKe/IKBKE & 99.79 & 99.08 & 99.43 & $3.50 \mathrm{E}-10$ & & \\
\hline IR & 91.43 & 90.38 & 90.91 & $1.60 \mathrm{E}-08$ & & \\
\hline IRAK1 & 114.99 & 114.14 & 114.57 & $5.41 \mathrm{E}-08$ & & \\
\hline IRAK4 & 94.01 & 92.76 & 93.39 & $3.84 \mathrm{E}-09$ & & \\
\hline IRR/INSRR & 94.69 & 94.54 & 94.62 & $1.64 \mathrm{E}-08$ & & \\
\hline ITK & 101.59 & 101.46 & 101.53 & $1.29 \mathrm{E}-08$ & & \\
\hline JAK1 & 87.31 & 86.98 & 87.15 & $3.89 \mathrm{E}-10$ & & \\
\hline JAK2 & 74.70 & 73.98 & 74.34 & $3.94 \mathrm{E}-10$ & & \\
\hline JAK3 & 107.13 & 103.55 & 105.34 & $1.04 \mathrm{E}-10$ & & \\
\hline JNK1 & 98.67 & 95.39 & 97.03 & $8.29 \mathrm{E}-07$ & & \\
\hline JNK2 & 102.91 & 101.90 & 102.40 & $2.53 \mathrm{E}-06$ & & \\
\hline JNK3 & 97.84 & 97.07 & 97.45 & ND & $3.06 \mathrm{E}-07$ & JNKi VIII \\
\hline KDR/VEGFR2 & 96.26 & 95.64 & 95.95 & $1.12 \mathrm{E}-08$ & & \\
\hline KHS/MAP4K5 & 93.05 & 92.03 & 92.54 & $2.41 \mathrm{E}-10$ & & \\
\hline LATS1 & 99.84 & 98.07 & 98.96 & $9.89 \mathrm{E}-09$ & & \\
\hline LATS2 & 93.09 & 91.19 & 92.14 & $5.78 \mathrm{E}-09$ & & \\
\hline LCK & 72.09 & 71.93 & 72.01 & $1.76 \mathrm{E}-09$ & & \\
\hline LCK2/ICK & 92.03 & 89.55 & 90.79 & $4.29 \mathrm{E}-08$ & & \\
\hline LIMK1 & 92.18 & 89.27 & 90.73 & 2.91E-09 & & \\
\hline LIMK2 & 73.30 & 71.69 & 72.50 & $1.30 \mathrm{E}-07$ & & \\
\hline LKB1 & 96.36 & 96.34 & 96.35 & $8.20 \mathrm{E}-08$ & & \\
\hline LOK/STK10 & 93.17 & 91.56 & 92.36 & $1.19 \mathrm{E}-08$ & & \\
\hline LRRK2 & 92.09 & 90.68 & 91.38 & $9.37 \mathrm{E}-09$ & & \\
\hline LYN & 6.05 & 5.84 & 5.95 & $8.68 \mathrm{E}-10$ & & \\
\hline LYN B & 4.87 & 3.79 & 4.33 & 4.34E-09 & & \\
\hline MAPKAPK2 & 96.32 & 94.01 & 95.16 & $1.35 \mathrm{E}-07$ & & \\
\hline MAPKAPK3 & 102.78 & 102.56 & 102.67 & $5.27 \mathrm{E}-06$ & & \\
\hline MAPKAPK5/PRAK & 96.99 & 96.47 & 96.73 & $3.41 \mathrm{E}-07$ & & \\
\hline MARK1 & 91.66 & 89.71 & 90.68 & $2.15 \mathrm{E}-10$ & & \\
\hline MARK2/PAR-1Ba & 95.01 & 94.69 & 94.85 & $1.13 \mathrm{E}-10$ & & \\
\hline MARK3 & 103.83 & 101.56 & 102.69 & $2.93 \mathrm{E}-10$ & & \\
\hline MARK4 & 100.61 & 98.61 & 99.61 & $1.21 \mathrm{E}-10$ & & \\
\hline MEK1 & 108.30 & 103.84 & 106.07 & $3.12 \mathrm{E}-08$ & & \\
\hline MEK2 & 99.21 & 96.54 & 97.88 & $4.35 \mathrm{E}-08$ & & \\
\hline MEK3 & 99.86 & 99.42 & 99.64 & $2.32 \mathrm{E}-08$ & & \\
\hline MEKK1 & 102.71 & 101.55 & 102.13 & $5.69 \mathrm{E}-07$ & & \\
\hline MEKK2 & 87.97 & 86.69 & 87.33 & $1.33 \mathrm{E}-08$ & & \\
\hline MEKK3 & 115.34 & 112.06 & 113.70 & 4.63E-08 & & \\
\hline MELK & 109.87 & 106.01 & 107.94 & $6.89 \mathrm{E}-10$ & & \\
\hline MINK/MINK1 & 100.20 & 100.15 & 100.18 & $7.34 \mathrm{E}-10$ & & \\
\hline MKK4 & 100.45 & 98.92 & 99.69 & $1.64 \mathrm{E}-06$ & & \\
\hline MKK6 & 104.87 & 103.90 & 104.38 & $5.99 \mathrm{E}-09$ & & \\
\hline MLCK/MYLK & 97.72 & 96.93 & 97.32 & 8.77E-08 & & \\
\hline MLCK2/MYLK2 & 98.81 & 97.10 & 97.95 & $1.61 \mathrm{E}-08$ & & \\
\hline MLK1/MAP3K9 & 98.49 & 98.16 & 98.33 & $1.55 \mathrm{E}-09$ & & \\
\hline MLK2/MAP3K10 & 98.73 & 97.91 & 98.32 & 2.69E-09 & & \\
\hline MLK3/MAP3K11 & 96.99 & 96.30 & 96.64 & 3.65E-09 & & \\
\hline MNK1 & 98.24 & 95.68 & 96.96 & $5.58 \mathrm{E}-08$ & & \\
\hline MNK2 & 100.00 & 99.65 & 99.83 & $2.04 \mathrm{E}-08$ & & \\
\hline MRCKa/CDC42BPA & 98.42 & 98.09 & 98.26 & $6.71 \mathrm{E}-09$ & & \\
\hline
\end{tabular}




\begin{tabular}{|c|c|c|c|c|c|c|}
\hline MRCKb/CDC42BPB & 92.25 & 90.15 & 91.20 & $3.59 \mathrm{E}-09$ & & \\
\hline MSK1/RPS6KA5 & 108.19 & 102.06 & 105.13 & $6.90 \mathrm{E}-10$ & & \\
\hline MSK2/RPS6KA4 & 85.22 & 80.69 & 82.96 & $1.83 \mathrm{E}-09$ & & \\
\hline MSSK1/STK23 & 94.21 & 93.52 & 93.86 & $1.62 \mathrm{E}-06$ & & \\
\hline MST1/STK4 & 92.18 & 91.01 & 91.60 & $1.78 \mathrm{E}-09$ & & \\
\hline MST2/STK3 & 101.32 & 101.13 & 101.23 & 3.32E-09 & & \\
\hline MST3/STK24 & 98.06 & 96.35 & 97.21 & $2.62 \mathrm{E}-09$ & & \\
\hline MST4 & 97.08 & 96.58 & 96.83 & $3.34 \mathrm{E}-09$ & & \\
\hline MUSK & 90.73 & 84.02 & 87.38 & $1.21 \mathrm{E}-07$ & & \\
\hline MYLK3 & 99.90 & 98.98 & 99.44 & $1.82 \mathrm{E}-07$ & & \\
\hline MYO3b & 98.51 & 98.32 & 98.42 & $5.17 \mathrm{E}-09$ & & \\
\hline NEK1 & 94.87 & 94.75 & 94.81 & $1.73 \mathrm{E}-08$ & & \\
\hline NEK11 & 104.83 & 103.72 & 104.28 & $1.31 \mathrm{E}-06$ & & \\
\hline NEK2 & 98.70 & 98.07 & 98.38 & $5.07 \mathrm{E}-07$ & & \\
\hline NEK3 & 106.32 & 106.18 & 106.25 & $>2.00 \mathrm{E}-05$ & & \\
\hline NEK4 & 104.65 & 101.59 & 103.12 & $6.81 \mathrm{E}-08$ & & \\
\hline NEK5 & 91.76 & 91.50 & 91.63 & $5.93 \mathrm{E}-08$ & & \\
\hline NEK6 & 93.92 & 91.10 & 92.51 & ND & $8.34 \mathrm{E}-06$ & PKR Inhibitor \\
\hline NEK7 & 94.45 & 91.32 & 92.88 & ND & $2.19 \mathrm{E}-06$ & PKR Inhibitor \\
\hline NEK9 & 96.89 & 96.87 & 96.88 & $1.04 \mathrm{E}-07$ & & \\
\hline NLK & 96.33 & 95.12 & 95.73 & 5.84E-08 & & \\
\hline OSR1/OXSR1 & 98.34 & 97.62 & 97.98 & $6.87 \mathrm{E}-08$ & & \\
\hline P38a/MAPK14 & 104.67 & 100.89 & 102.78 & ND & $2.04 \mathrm{E}-08$ & SB202190 \\
\hline P38b/MAPK11 & 99.09 & 96.41 & 97.75 & ND & $2.64 \mathrm{E}-08$ & SB202190 \\
\hline P38d/MAPK13 & 97.05 & 95.83 & 96.44 & $1.21 \mathrm{E}-07$ & & \\
\hline P38g & 99.70 & 98.20 & 98.95 & $2.18 \mathrm{E}-07$ & & \\
\hline p70S6K/RPS6KB1 & 99.96 & 98.35 & 99.16 & $5.69 \mathrm{E}-10$ & & \\
\hline p70S6Kb/RPS6KB2 & 99.73 & 94.93 & 97.33 & 2.67E-09 & & \\
\hline PAK1 & 100.66 & 100.28 & 100.47 & $5.07 \mathrm{E}-10$ & & \\
\hline PAK2 & 99.49 & 99.36 & 99.43 & $2.96 \mathrm{E}-09$ & & \\
\hline PAK3 & 102.06 & 99.32 & 100.69 & 4.12E-10 & & \\
\hline PAK4 & 94.18 & 93.46 & 93.82 & $2.26 \mathrm{E}-08$ & & \\
\hline PAK5 & 102.54 & 102.43 & 102.48 & $3.25 \mathrm{E}-09$ & & \\
\hline PAK6 & 99.31 & 98.98 & 99.15 & $6.22 \mathrm{E}-08$ & & \\
\hline PASK & 94.22 & 91.31 & 92.77 & $1.56 \mathrm{E}-08$ & & \\
\hline PBK/TOPK & 109.73 & 105.61 & 107.67 & $9.35 \mathrm{E}-08$ & & \\
\hline PDGFRa & 80.16 & 78.21 & 79.19 & $8.16 \mathrm{E}-10$ & & \\
\hline PDGFRb & 90.17 & 89.87 & 90.02 & $3.17 \mathrm{E}-09$ & & \\
\hline PDK1/PDPK1 & 105.07 & 104.15 & 104.61 & 4.64E-10 & & \\
\hline PHKg1 & 100.03 & 99.30 & 99.67 & 2.53E-09 & & \\
\hline PHKg2 & 95.49 & 94.40 & 94.95 & $1.03 \mathrm{E}-09$ & & \\
\hline PIM1 & 98.98 & 98.46 & 98.72 & $5.11 \mathrm{E}-09$ & & \\
\hline PIM2 & 103.09 & 100.81 & 101.95 & 4.07E-08 & & \\
\hline PIM3 & 94.43 & 94.10 & 94.27 & $1.34 \mathrm{E}-10$ & & \\
\hline PKA & 95.32 & 92.90 & 94.11 & $9.30 \mathrm{E}-10$ & & \\
\hline PKAcb & 107.21 & 105.48 & 106.35 & $1.52 \mathrm{E}-09$ & & \\
\hline PKAcg & 105.86 & 103.91 & 104.89 & 5.93E-09 & & \\
\hline $\mathrm{PKCa}$ & 98.43 & 97.92 & 98.18 & $3.55 \mathrm{E}-10$ & & \\
\hline PKCb1 & 100.11 & 98.20 & 99.16 & $1.44 \mathrm{E}-08$ & & \\
\hline $\mathrm{PKCb} 2$ & 90.98 & 90.22 & 90.60 & $1.93 \mathrm{E}-09$ & & \\
\hline PKCd & 120.04 & 104.26 & 112.15 & $1.83 \mathrm{E}-10$ & & \\
\hline PKCepsilon & 96.07 & 96.02 & 96.05 & $2.23 \mathrm{E}-10$ & & \\
\hline PKCeta & 93.92 & 93.02 & 93.47 & $1.06 \mathrm{E}-09$ & & \\
\hline PKCg & 94.74 & 92.05 & 93.40 & $1.38 \mathrm{E}-09$ & & \\
\hline PKCiota & 106.04 & 102.11 & 104.07 & $2.31 \mathrm{E}-08$ & & \\
\hline
\end{tabular}




\begin{tabular}{|c|c|c|c|c|c|c|}
\hline PKCmu/PRKD1 & 92.08 & 91.08 & 91.58 & $1.48 \mathrm{E}-09$ & & \\
\hline PKCnu/PRKD3 & 96.95 & 95.64 & 96.30 & $9.09 \mathrm{E}-10$ & & \\
\hline PKCtheta & 119.64 & 118.21 & 118.92 & $9.29 \mathrm{E}-10$ & & \\
\hline PKCzeta & 102.04 & 99.30 & 100.67 & $7.08 \mathrm{E}-08$ & & \\
\hline PKD2/PRKD2 & 92.68 & 91.17 & 91.92 & $1.39 \mathrm{E}-09$ & & \\
\hline PKG1a & 97.71 & 96.74 & 97.23 & $3.69 \mathrm{E}-09$ & & \\
\hline PKG1b & 82.34 & 80.94 & 81.64 & $3.64 \mathrm{E}-09$ & & \\
\hline PKG2/PRKG2 & 85.23 & 83.94 & 84.59 & $1.48 \mathrm{E}-08$ & & \\
\hline PKN1/PRK1 & 120.19 & 112.74 & 116.46 & $4.98 \mathrm{E}-09$ & & \\
\hline PKN2/PRK2 & 112.91 & 103.99 & 108.45 & $3.31 \mathrm{E}-09$ & & \\
\hline PKN3/PRK3 & 104.94 & 103.91 & 104.43 & $1.09 \mathrm{E}-08$ & & \\
\hline PLK1 & 104.21 & 103.78 & 103.99 & $2.53 \mathrm{E}-07$ & & \\
\hline PLK2 & 97.07 & 96.93 & 97.00 & $2.53 \mathrm{E}-07$ & & \\
\hline PLK3 & 106.53 & 106.30 & 106.42 & $2.01 \mathrm{E}-07$ & & \\
\hline PLK4/SAK & 96.09 & 94.23 & 95.16 & 8.67E-09 & & \\
\hline PRKX & 111.62 & 110.34 & 110.98 & $2.48 \mathrm{E}-09$ & & \\
\hline PYK2 & 96.91 & 96.69 & 96.80 & $9.12 \mathrm{E}-09$ & & \\
\hline RAF1 & 95.81 & 95.72 & 95.76 & ND & $1.05 \mathrm{E}-08$ & GW5074 \\
\hline RET & 94.38 & 92.20 & 93.29 & $2.32 \mathrm{E}-09$ & & \\
\hline RIPK2 & 82.99 & 82.97 & 82.98 & $4.35 \mathrm{E}-07$ & & \\
\hline RIPK3 & 96.14 & 95.74 & 95.94 & ND & $2.31 \mathrm{E}-06$ & GW5074 \\
\hline RIPK5 & 89.60 & 86.62 & 88.11 & $4.98 \mathrm{E}-08$ & & \\
\hline ROCK1 & 106.95 & 104.53 & 105.74 & $7.65 \mathrm{E}-10$ & & \\
\hline ROCK2 & 99.31 & 98.41 & 98.86 & $6.52 \mathrm{E}-10$ & & \\
\hline RON/MST1R & 97.13 & 95.42 & 96.28 & $2.10 \mathrm{E}-07$ & & \\
\hline ROS/ROS1 & 93.73 & 93.10 & 93.42 & $1.74 \mathrm{E}-10$ & & \\
\hline RSK1 & 101.49 & 99.55 & 100.52 & $1.72 \mathrm{E}-10$ & & \\
\hline RSK2 & 94.19 & 91.17 & 92.68 & $1.23 \mathrm{E}-10$ & & \\
\hline RSK3 & 100.51 & 99.79 & 100.15 & $2.69 \mathrm{E}-10$ & & \\
\hline RSK4 & 87.08 & 86.68 & 86.88 & $1.29 \mathrm{E}-10$ & & \\
\hline SGK1 & 81.36 & 81.15 & 81.26 & $8.66 \mathrm{E}-09$ & & \\
\hline SGK2 & 97.02 & 96.25 & 96.64 & $1.27 \mathrm{E}-08$ & & \\
\hline SGK3/SGKL & 102.96 & 102.15 & 102.55 & $1.76 \mathrm{E}-07$ & & \\
\hline SIK1 & 72.05 & 71.52 & 71.78 & $6.22 \mathrm{E}-10$ & & \\
\hline SIK2 & 67.31 & 66.61 & 66.96 & $3.14 \mathrm{E}-10$ & & \\
\hline SIK3 & 90.94 & 89.92 & 90.43 & $5.21 \mathrm{E}-10$ & & \\
\hline SLK/STK2 & 105.12 & 100.76 & 102.94 & $1.70 \mathrm{E}-08$ & & \\
\hline SNARK/NUAK2 & 105.01 & 104.88 & 104.95 & $3.12 \mathrm{E}-08$ & & \\
\hline SRMS & 93.70 & 93.47 & 93.58 & $8.92 \mathrm{E}-06$ & & \\
\hline SRPK1 & 93.37 & 89.31 & 91.34 & $2.85 \mathrm{E}-08$ & & \\
\hline SRPK2 & 108.84 & 106.63 & 107.73 & $2.80 \mathrm{E}-07$ & & \\
\hline SSTK/TSSK6 & 100.55 & 100.43 & 100.49 & $1.46 \mathrm{E}-07$ & & \\
\hline STK16 & 100.64 & 99.37 & 100.01 & $2.47 \mathrm{E}-07$ & & \\
\hline STK22D/TSSK1 & 85.75 & 83.51 & 84.63 & $<7.63 \mathrm{E}-11$ & & \\
\hline STK25/YSK1 & 105.35 & 103.12 & 104.24 & $2.00 \mathrm{E}-09$ & & \\
\hline STK32B/YANK2 & 104.24 & 99.86 & 102.05 & $1.57 \mathrm{E}-07$ & & \\
\hline STK32C/YANK3 & 101.00 & 99.55 & 100.27 & $3.83 \mathrm{E}-07$ & & \\
\hline STK33 & 81.99 & 80.40 & 81.20 & $3.78 \mathrm{E}-08$ & & \\
\hline STK38/NDR1 & 93.73 & 90.14 & 91.94 & $1.15 \mathrm{E}-08$ & & \\
\hline STK38L/NDR2 & 94.69 & 94.19 & 94.44 & $1.28 \mathrm{E}-09$ & & \\
\hline STK39/STLK3 & 94.61 & 93.13 & 93.87 & $2.62 \mathrm{E}-08$ & & \\
\hline SYK & 98.07 & 97.76 & 97.91 & $4.63 \mathrm{E}-10$ & & \\
\hline TAK1 & 101.50 & 101.43 & 101.47 & $5.07 \mathrm{E}-08$ & & \\
\hline TAOK1 & 97.98 & 95.83 & 96.91 & $1.22 \mathrm{E}-09$ & & \\
\hline TAOK2/TAO1 & 100.70 & 100.63 & 100.66 & $7.44 \mathrm{E}-09$ & & \\
\hline
\end{tabular}




\begin{tabular}{|c|c|c|c|c|c|c|}
\hline TAOK3/JIK & 93.92 & 92.17 & 93.05 & 2.02E-09 & & \\
\hline TBK1 & 99.74 & 96.45 & 98.09 & $3.03 \mathrm{E}-09$ & & \\
\hline TEC & 98.65 & 97.03 & 97.84 & 5.74E-08 & & \\
\hline TESK1 & 102.49 & 100.97 & 101.73 & $6.26 \mathrm{E}-07$ & & \\
\hline TGFBR2 & 102.81 & 100.94 & 101.87 & ND & 8.99E-08 & LDN193189 \\
\hline TIE2/TEK & 98.54 & 97.93 & 98.23 & 8.30E-08 & & \\
\hline TLK1 & 106.35 & 104.34 & 105.34 & $2.16 \mathrm{E}-08$ & & \\
\hline TLK2 & 103.67 & 102.60 & 103.13 & $3.10 \mathrm{E}-09$ & & \\
\hline TNIK & 94.42 & 93.91 & 94.17 & $4.84 \mathrm{E}-10$ & & \\
\hline TNK1 & 94.72 & 93.86 & 94.29 & $2.26 \mathrm{E}-09$ & & \\
\hline TRKA & 91.21 & 89.91 & 90.56 & $1.53 \mathrm{E}-09$ & & \\
\hline TRKB & 97.13 & 96.67 & 96.90 & 9.34E-11 & & \\
\hline TRKC & 84.82 & 84.44 & 84.63 & $2.84 \mathrm{E}-10$ & & \\
\hline TSSK2 & 100.89 & 100.69 & 100.79 & $6.02 \mathrm{E}-09$ & & \\
\hline TSSK3/STK22C & 109.54 & 107.61 & 108.58 & 5.33E-09 & & \\
\hline TTBK1 & 100.31 & 99.10 & 99.71 & ND & $>2.00 \mathrm{E}-05$ & SB202190 \\
\hline TTBK2 & 121.19 & 116.68 & 118.93 & ND & $7.51 \mathrm{E}-06$ & SB202190 \\
\hline TXK & 86.65 & 84.62 & 85.63 & $3.60 \mathrm{E}-08$ & & \\
\hline TYK1/LTK & 98.59 & 97.10 & 97.84 & 2.97E-08 & & \\
\hline TYK2 & 95.80 & 95.18 & 95.49 & $2.44 \mathrm{E}-10$ & & \\
\hline TYRO3/SKY & 98.80 & 98.45 & 98.62 & $3.55 \mathrm{E}-09$ & & \\
\hline ULK1 & 98.97 & 97.19 & 98.08 & $7.58 \mathrm{E}-09$ & & \\
\hline ULK2 & 104.09 & 98.50 & 101.29 & $2.01 \mathrm{E}-09$ & & \\
\hline ULK3 & 93.04 & 91.84 & 92.44 & $6.61 \mathrm{E}-09$ & & \\
\hline VRK1 & 120.44 & 115.26 & 117.85 & ND & $9.85 \mathrm{E}-07$ & Ro-31-8220 \\
\hline VRK2 & 86.70 & 82.46 & 84.58 & ND & $2.80 \mathrm{E}-05$ & Ro-31-8220 \\
\hline WEE1 & 109.20 & 105.61 & 107.41 & ND & $6.66 \mathrm{E}-07$ & Wee-1 Inhibitor \\
\hline WNK1 & 91.91 & 94.67 & 93.29 & $1.26 \mathrm{E}-05$ & & \\
\hline WNK2 & 96.75 & 94.80 & 95.78 & $1.15 \mathrm{E}-06$ & & \\
\hline WNK3 & 97.09 & 95.89 & 96.49 & ND & $2.51 \mathrm{E}-06$ & Wee-1 Inhibitor \\
\hline YES/YES1 & 34.10 & 32.74 & 33.42 & $2.78 \mathrm{E}-09$ & & \\
\hline ZAK/MLTK & 100.02 & 96.37 & 98.20 & ND & $1.32 \mathrm{E}-06$ & GW5074 \\
\hline ZAP70 & 102.08 & 101.00 & 101.54 & $1.05 \mathrm{E}-08$ & & \\
\hline ZIPK/DAPK3 & 106.51 & 105.14 & 105.82 & 2.69E-09 & & \\
\hline CDK14/cyclin Y (PFTK1) & 98.67 & 98.02 & 98.35 & $4.76 \mathrm{E}-08$ & & \\
\hline CDK17/cyclin Y (PCTK2) & 92.57 & 92.40 & 92.49 & $1.19 \mathrm{E}-08$ & & \\
\hline CDK18/cyclin Y (PCTK3) & 101.88 & 99.59 & 100.73 & $2.20 \mathrm{E}-08$ & & \\
\hline CDK2/cyclin O & 83.78 & 81.25 & 82.51 & $1.67 \mathrm{E}-09$ & & \\
\hline CK1a1L & 99.76 & 94.67 & 97.22 & $1.85 \mathrm{E}-06$ & & \\
\hline ERN2/IRE2 & 89.64 & 89.47 & 89.55 & $3.68 \mathrm{E}-08$ & & \\
\hline KSR1 & 102.47 & 102.08 & 102.28 & $7.88 \mathrm{E}-06$ & & \\
\hline KSR2 & 103.24 & 101.04 & 102.14 & 4.44E-06 & & \\
\hline MAK & 98.27 & 97.98 & 98.12 & $2.40 \mathrm{E}-08$ & & \\
\hline MEKK6 & 96.98 & 96.26 & 96.62 & $6.06 \mathrm{E}-07$ & & \\
\hline MKK7 & 98.63 & 97.72 & 98.17 & $6.13 \mathrm{E}-07$ & & \\
\hline MLK4 & 97.17 & 94.42 & 95.80 & $6.94 \mathrm{E}-07$ & & \\
\hline MYO3A & 99.87 & 96.96 & 98.41 & $2.11 \mathrm{E}-08$ & & \\
\hline NIM1 & 103.86 & 103.47 & 103.67 & $1.38 \mathrm{E}-07$ & & \\
\hline PEAK1 & 0.03 & -0.19 & -0.08 & $2.87 \mathrm{E}-09$ & & \\
\hline STK21/CIT & 100.89 & 100.35 & 100.62 & $5.81 \mathrm{E}-07$ & & \\
\hline YSK4/MAP3K19 & 104.33 & 103.40 & 103.86 & $1.78 \mathrm{E}-08$ & & \\
\hline
\end{tabular}

Table S2. Selected RBC kinase $\mathrm{IC}_{50}$ 's for compound 6. 


\begin{tabular}{|c|c|c|c|}
\hline \multicolumn{4}{|l|}{ ABL } \\
\hline Cpd 6 conc.(M) & Enzyme activity & Staurosporine Conc.(M) & Enzyme activity \\
\hline $3.00 \mathrm{E}-05$ & 98.33 & $2.00 \mathrm{E}-05$ & 2.74 \\
\hline $1.00 \mathrm{E}-05$ & 92.94 & $5.00 \mathrm{E}-06$ & 7.07 \\
\hline $3.33 \mathrm{E}-06$ & 97.16 & $1.25 \mathrm{E}-06$ & 7.05 \\
\hline $1.11 \mathrm{E}-06$ & 94.95 & $3.13 \mathrm{E}-07$ & 19.95 \\
\hline $3.70 \mathrm{E}-07$ & 107.79 & $7.81 \mathrm{E}-08$ & 50.45 \\
\hline $1.23 \mathrm{E}-07$ & 96.59 & $1.95 \mathrm{E}-08$ & 81.15 \\
\hline $4.12 \mathrm{E}-08$ & 97.49 & $4.88 \mathrm{E}-09$ & 89.98 \\
\hline $1.37 \mathrm{E}-08$ & 93.19 & $1.22 \mathrm{E}-09$ & 93.89 \\
\hline 4.57E-09 & 90.31 & $3.05 \mathrm{E}-10$ & 97.84 \\
\hline $1.52 \mathrm{E}-09$ & 97.70 & $7.63 \mathrm{E}-11$ & 97.27 \\
\hline DMSO & 97.58 & DMSO & 102.42 \\
\hline \multicolumn{4}{|l|}{ ABL2/ARG } \\
\hline Cpd 6 conc.(M) & Enzyme activity & Staurosporine Conc.(M) & Enzyme activity \\
\hline $3.00 \mathrm{E}-05$ & 104.12 & $2.00 \mathrm{E}-05$ & 0.61 \\
\hline $1.00 \mathrm{E}-05$ & 100.40 & $5.00 \mathrm{E}-06$ & 4.26 \\
\hline $3.33 \mathrm{E}-06$ & 102.36 & $1.25 \mathrm{E}-06$ & -1.38 \\
\hline $1.11 \mathrm{E}-06$ & 95.38 & $3.13 \mathrm{E}-07$ & 7.51 \\
\hline $3.70 \mathrm{E}-07$ & 107.27 & $7.81 \mathrm{E}-08$ & 24.18 \\
\hline $1.23 \mathrm{E}-07$ & 100.95 & $1.95 \mathrm{E}-08$ & 56.54 \\
\hline $4.12 \mathrm{E}-08$ & 93.52 & 4.88E-09 & 81.06 \\
\hline $1.37 \mathrm{E}-08$ & 103.77 & $1.22 \mathrm{E}-09$ & 95.09 \\
\hline 4.57E-09 & 99.09 & $3.05 \mathrm{E}-10$ & 101.43 \\
\hline $1.52 \mathrm{E}-09$ & 104.61 & $7.63 \mathrm{E}-11$ & 105.90 \\
\hline DMSO & 102.74 & DMSO & 97.26 \\
\hline \multicolumn{4}{|l|}{ BLK } \\
\hline Cpd 6 conc.(M) & Enzyme activity & Staurosporine Conc.(M) & Enzyme activity \\
\hline $3.00 \mathrm{E}-05$ & 105.18 & $2.00 \mathrm{E}-05$ & 0.80 \\
\hline $1.00 \mathrm{E}-05$ & 114.05 & $5.00 \mathrm{E}-06$ & 0.08 \\
\hline $3.33 \mathrm{E}-06$ & 115.89 & $1.25 \mathrm{E}-06$ & 0.00 \\
\hline $1.11 \mathrm{E}-06$ & 109.10 & $3.13 \mathrm{E}-07$ & 1.44 \\
\hline $3.70 \mathrm{E}-07$ & 111.82 & $7.81 \mathrm{E}-08$ & 0.75 \\
\hline $1.23 \mathrm{E}-07$ & 104.12 & $1.95 \mathrm{E}-08$ & 7.82 \\
\hline $4.12 \mathrm{E}-08$ & 92.30 & $4.88 \mathrm{E}-09$ & 22.55 \\
\hline $1.37 \mathrm{E}-08$ & 104.06 & $1.22 \mathrm{E}-09$ & 53.54 \\
\hline 4.57E-09 & 107.30 & $3.05 \mathrm{E}-10$ & 85.52 \\
\hline $1.52 \mathrm{E}-09$ & 102.44 & $7.63 \mathrm{E}-11$ & 98.94 \\
\hline DMSO & 102.34 & DMSO & 97.66 \\
\hline \multicolumn{4}{|l|}{ c-Src } \\
\hline Cpd 6 conc.(M) & Enzyme activity & Staurosporine Conc.(M) & Enzyme activity \\
\hline $3.00 \mathrm{E}-05$ & 104.49 & $2.00 \mathrm{E}-05$ & 0.45 \\
\hline
\end{tabular}




\begin{tabular}{|c|c|c|c|}
\hline $1.00 \mathrm{E}-05$ & 105.26 & $5.00 \mathrm{E}-06$ & 0.20 \\
\hline $3.33 \mathrm{E}-06$ & 106.77 & $1.25 \mathrm{E}-06$ & 0.93 \\
\hline $1.11 \mathrm{E}-06$ & 106.08 & $3.13 \mathrm{E}-07$ & 0.59 \\
\hline $3.70 \mathrm{E}-07$ & 110.78 & 7.81E-08 & 4.41 \\
\hline $1.23 \mathrm{E}-07$ & 103.01 & $1.95 \mathrm{E}-08$ & 15.49 \\
\hline 4.12E-08 & 102.80 & 4.88E-09 & 43.50 \\
\hline $1.37 \mathrm{E}-08$ & 107.86 & $1.22 \mathrm{E}-09$ & 76.88 \\
\hline 4.57E-09 & 105.08 & $3.05 \mathrm{E}-10$ & 95.14 \\
\hline $1.52 \mathrm{E}-09$ & 102.59 & $7.63 \mathrm{E}-11$ & 101.02 \\
\hline DMSO & 100.72 & DMSO & 99.28 \\
\hline \multicolumn{4}{|l|}{ DDR2 } \\
\hline Cpd 6 conc.(M) & Enzyme activity & Staurosporine Conc.(M) & Enzyme activity \\
\hline $3.00 \mathrm{E}-05$ & 96.47 & $2.00 \mathrm{E}-05$ & 5.82 \\
\hline $1.00 \mathrm{E}-05$ & 112.30 & $5.00 \mathrm{E}-06$ & 5.55 \\
\hline $3.33 \mathrm{E}-06$ & 103.48 & $1.25 \mathrm{E}-06$ & 6.04 \\
\hline $1.11 \mathrm{E}-06$ & 100.72 & $3.13 \mathrm{E}-07$ & 2.66 \\
\hline $3.70 \mathrm{E}-07$ & 107.16 & $7.81 \mathrm{E}-08$ & 7.44 \\
\hline $1.23 \mathrm{E}-07$ & 106.72 & $1.95 \mathrm{E}-08$ & 0.98 \\
\hline 4.12E-08 & 99.08 & 4.88E-09 & 6.55 \\
\hline $1.37 \mathrm{E}-08$ & 100.39 & $1.22 \mathrm{E}-09$ & 8.95 \\
\hline $4.57 \mathrm{E}-09$ & 102.20 & $3.05 \mathrm{E}-10$ & 27.48 \\
\hline $1.52 \mathrm{E}-09$ & 94.46 & $7.63 \mathrm{E}-11$ & 66.47 \\
\hline DMSO & 100.33 & DMSO & 99.67 \\
\hline \multicolumn{4}{|l|}{ EPHA5 } \\
\hline Cpd 6 conc.(M) & Enzyme activity & Staurosporine Conc.(M) & Enzyme activity \\
\hline $3.00 \mathrm{E}-05$ & 100.32 & $2.00 \mathrm{E}-05$ & 3.30 \\
\hline $1.00 \mathrm{E}-05$ & 98.01 & $5.00 \mathrm{E}-06$ & 0.12 \\
\hline $3.33 \mathrm{E}-06$ & 100.04 & $1.25 \mathrm{E}-06$ & 3.46 \\
\hline $1.11 \mathrm{E}-06$ & 101.68 & $3.13 \mathrm{E}-07$ & 13.03 \\
\hline 3.70E-07 & 104.14 & 7.81E-08 & 33.81 \\
\hline $1.23 \mathrm{E}-07$ & 98.64 & $1.95 \mathrm{E}-08$ & 63.75 \\
\hline 4.12E-08 & 103.74 & $4.88 \mathrm{E}-09$ & 85.84 \\
\hline $1.37 \mathrm{E}-08$ & 101.31 & $1.22 \mathrm{E}-09$ & 98.24 \\
\hline 4.57E-09 & 96.20 & $3.05 \mathrm{E}-10$ & 97.83 \\
\hline $1.52 \mathrm{E}-09$ & 96.21 & $7.63 \mathrm{E}-11$ & 99.51 \\
\hline DMSO & 97.41 & DMSO & 102.59 \\
\hline \multicolumn{4}{|l|}{ EPHB2 } \\
\hline Cpd 6 conc.(M) & Enzyme activity & Staurosporine Conc.(M) & Enzyme activity \\
\hline $3.00 \mathrm{E}-05$ & 98.88 & $2.00 \mathrm{E}-05$ & 2.53 \\
\hline $1.00 \mathrm{E}-05$ & 97.76 & $5.00 \mathrm{E}-06$ & 4.92 \\
\hline $3.33 \mathrm{E}-06$ & 99.37 & $1.25 \mathrm{E}-06$ & 15.99 \\
\hline $1.11 \mathrm{E}-06$ & 95.58 & $3.13 \mathrm{E}-07$ & 40.87 \\
\hline
\end{tabular}




\begin{tabular}{|c|c|c|c|}
\hline $3.70 \mathrm{E}-07$ & 105.13 & $7.81 \mathrm{E}-08$ & 79.40 \\
\hline $1.23 \mathrm{E}-07$ & 98.81 & $1.95 \mathrm{E}-08$ & 94.41 \\
\hline 4.12E-08 & 100.11 & 4.88E-09 & 96.73 \\
\hline $1.37 \mathrm{E}-08$ & 99.74 & $1.22 \mathrm{E}-09$ & 98.77 \\
\hline $4.57 \mathrm{E}-09$ & 102.04 & $3.05 \mathrm{E}-10$ & 102.23 \\
\hline $1.52 \mathrm{E}-09$ & 98.77 & $7.63 \mathrm{E}-11$ & 104.62 \\
\hline DMSO & 96.32 & DMSO & 103.68 \\
\hline \multicolumn{4}{|l|}{ FGR } \\
\hline Cpd 6 conc.(M) & Enzyme activity & Staurosporine Conc.(M) & Enzyme activity \\
\hline $3.00 \mathrm{E}-05$ & 96.37 & $2.00 \mathrm{E}-05$ & 0.91 \\
\hline $1.00 \mathrm{E}-05$ & 100.80 & $5.00 \mathrm{E}-06$ & 2.33 \\
\hline $3.33 \mathrm{E}-06$ & 97.69 & $1.25 \mathrm{E}-06$ & 0.81 \\
\hline $1.11 \mathrm{E}-06$ & 97.44 & $3.13 \mathrm{E}-07$ & 2.49 \\
\hline $3.70 \mathrm{E}-07$ & 102.69 & 7.81E-08 & 2.96 \\
\hline $1.23 \mathrm{E}-07$ & 100.61 & $1.95 \mathrm{E}-08$ & 9.31 \\
\hline 4.12E-08 & 98.83 & $4.88 \mathrm{E}-09$ & 26.92 \\
\hline $1.37 \mathrm{E}-08$ & 101.46 & $1.22 \mathrm{E}-09$ & 60.64 \\
\hline $4.57 \mathrm{E}-09$ & 102.36 & $3.05 \mathrm{E}-10$ & 85.70 \\
\hline $1.52 \mathrm{E}-09$ & 94.16 & $7.63 \mathrm{E}-11$ & 100.29 \\
\hline DMSO & 100.08 & DMSO & 99.92 \\
\hline \multicolumn{4}{|l|}{ FRK/PTK5 } \\
\hline Cpd 6 conc.(M) & Enzyme activity & Staurosporine Conc.(M) & Enzyme activity \\
\hline $3.00 \mathrm{E}-05$ & 96.26 & $2.00 \mathrm{E}-05$ & 2.80 \\
\hline $1.00 \mathrm{E}-05$ & 99.42 & $5.00 \mathrm{E}-06$ & 2.66 \\
\hline $3.33 \mathrm{E}-06$ & 99.23 & $1.25 \mathrm{E}-06$ & 6.60 \\
\hline $1.11 \mathrm{E}-06$ & 100.58 & $3.13 \mathrm{E}-07$ & 15.18 \\
\hline $3.70 \mathrm{E}-07$ & 105.20 & 7.81E-08 & 40.82 \\
\hline $1.23 \mathrm{E}-07$ & 101.95 & $1.95 \mathrm{E}-08$ & 73.53 \\
\hline 4.12E-08 & 97.18 & $4.88 \mathrm{E}-09$ & 90.91 \\
\hline $1.37 \mathrm{E}-08$ & 99.10 & $1.22 \mathrm{E}-09$ & 99.50 \\
\hline 4.57E-09 & 102.00 & $3.05 \mathrm{E}-10$ & 97.41 \\
\hline $1.52 \mathrm{E}-09$ & 97.05 & $7.63 \mathrm{E}-11$ & 99.46 \\
\hline DMSO & 101.41 & DMSO & 98.59 \\
\hline \multicolumn{4}{|l|}{ FYN } \\
\hline Cpd 6 conc.(M) & Enzyme activity & Staurosporine Conc.(M) & Enzyme activity \\
\hline $3.00 \mathrm{E}-05$ & 104.38 & $2.00 \mathrm{E}-05$ & 1.53 \\
\hline $1.00 \mathrm{E}-05$ & 105.58 & $5.00 \mathrm{E}-06$ & 1.32 \\
\hline $3.33 \mathrm{E}-06$ & 103.91 & $1.25 \mathrm{E}-06$ & -0.20 \\
\hline $1.11 \mathrm{E}-06$ & 106.37 & $3.13 \mathrm{E}-07$ & 3.03 \\
\hline $3.70 \mathrm{E}-07$ & 110.39 & 7.81E-08 & 4.85 \\
\hline $1.23 \mathrm{E}-07$ & 105.07 & $1.95 \mathrm{E}-08$ & 14.02 \\
\hline 4.12E-08 & 107.06 & $4.88 \mathrm{E}-09$ & 36.10 \\
\hline
\end{tabular}




\begin{tabular}{|c|c|c|c|}
\hline $1.37 \mathrm{E}-08$ & 102.69 & $1.22 \mathrm{E}-09$ & 67.94 \\
\hline 4.57E-09 & 105.18 & $3.05 \mathrm{E}-10$ & 94.32 \\
\hline $1.52 \mathrm{E}-09$ & 105.12 & $7.63 \mathrm{E}-11$ & 103.12 \\
\hline DMSO & 101.35 & DMSO & 98.65 \\
\hline \multicolumn{4}{|l|}{ LYN } \\
\hline Cpd 6 conc.(M) & Enzyme activity & Staurosporine Conc.(M) & Enzyme activity \\
\hline $3.00 \mathrm{E}-05$ & 99.76 & $2.00 \mathrm{E}-05$ & -0.25 \\
\hline $1.00 \mathrm{E}-05$ & 105.03 & $5.00 \mathrm{E}-06$ & 0.46 \\
\hline $3.33 \mathrm{E}-06$ & 103.88 & $1.25 \mathrm{E}-06$ & 0.07 \\
\hline $1.11 \mathrm{E}-06$ & 104.13 & $3.13 \mathrm{E}-07$ & 0.71 \\
\hline $3.70 \mathrm{E}-07$ & 108.88 & $7.81 \mathrm{E}-08$ & 2.43 \\
\hline $1.23 \mathrm{E}-07$ & 105.71 & $1.95 \mathrm{E}-08$ & 6.77 \\
\hline 4.12E-08 & 111.22 & 4.88E-09 & 16.61 \\
\hline $1.37 \mathrm{E}-08$ & 109.72 & $1.22 \mathrm{E}-09$ & 45.84 \\
\hline 4.57E-09 & 107.08 & $3.05 \mathrm{E}-10$ & 78.56 \\
\hline $1.52 \mathrm{E}-09$ & 101.33 & $7.63 \mathrm{E}-11$ & 97.56 \\
\hline DMSO & 98.94 & DMSO & 101.06 \\
\hline \multicolumn{4}{|l|}{ LYN B } \\
\hline Cpd 6 conc.(M) & Enzyme activity & Staurosporine Conc.(M) & Enzyme activity \\
\hline $3.00 \mathrm{E}-05$ & 104.27 & $2.00 \mathrm{E}-05$ & 1.14 \\
\hline $1.00 \mathrm{E}-05$ & 99.43 & $5.00 \mathrm{E}-06$ & -1.81 \\
\hline $3.33 \mathrm{E}-06$ & 103.19 & $1.25 \mathrm{E}-06$ & 0.78 \\
\hline $1.11 \mathrm{E}-06$ & 103.57 & $3.13 \mathrm{E}-07$ & 5.95 \\
\hline $3.70 \mathrm{E}-07$ & 104.45 & 7.81E-08 & 12.51 \\
\hline $1.23 \mathrm{E}-07$ & 108.95 & $1.95 \mathrm{E}-08$ & 27.74 \\
\hline 4.12E-08 & 108.18 & $4.88 \mathrm{E}-09$ & 58.22 \\
\hline $1.37 \mathrm{E}-08$ & 104.23 & $1.22 \mathrm{E}-09$ & 95.35 \\
\hline 4.57E-09 & 106.29 & $3.05 \mathrm{E}-10$ & 98.96 \\
\hline $1.52 \mathrm{E}-09$ & 103.48 & 7.63E-11 & 100.07 \\
\hline DMSO & 99.73 & DMSO & 100.27 \\
\hline \multicolumn{4}{|l|}{ PEAK1 } \\
\hline Cpd 6 conc.(M) & Enzyme activity & Staurosporine Conc.(M) & Enzyme activity \\
\hline $3.00 \mathrm{E}-05$ & 97.38 & $2.00 \mathrm{E}-05$ & -0.03 \\
\hline $1.00 \mathrm{E}-05$ & 99.90 & $5.00 \mathrm{E}-06$ & 0.20 \\
\hline $3.33 \mathrm{E}-06$ & 99.50 & $1.25 \mathrm{E}-06$ & 2.21 \\
\hline $1.11 \mathrm{E}-06$ & 99.77 & $3.13 \mathrm{E}-07$ & 0.96 \\
\hline $3.70 \mathrm{E}-07$ & 109.05 & 7.81E-08 & 5.86 \\
\hline $1.23 \mathrm{E}-07$ & 104.60 & $1.95 \mathrm{E}-08$ & 13.85 \\
\hline 4.12E-08 & 102.15 & 4.88E-09 & 39.71 \\
\hline $1.37 \mathrm{E}-08$ & 100.23 & $1.22 \mathrm{E}-09$ & 73.35 \\
\hline 4.57E-09 & 104.45 & $3.05 \mathrm{E}-10$ & 91.74 \\
\hline $1.52 \mathrm{E}-09$ & 100.00 & 7.63E-11 & 94.28 \\
\hline
\end{tabular}




\begin{tabular}{|c|c|c|c|}
\hline DMSO & 97.95 & DMSO & 102.05 \\
\hline YES/YES1 & \multicolumn{5}{|l|}{} \\
\hline Cpd 6 conc.(M) & Enzyme activity & Staurosporine Conc.(M) & Enzyme activity \\
\hline $3.00 \mathrm{E}-05$ & 98.37 & $2.00 \mathrm{E}-05$ & 0.44 \\
\hline $1.00 \mathrm{E}-05$ & 101.54 & $5.00 \mathrm{E}-06$ & 0.36 \\
\hline $3.33 \mathrm{E}-06$ & 92.69 & $1.25 \mathrm{E}-06$ & 1.15 \\
\hline $1.11 \mathrm{E}-06$ & 95.73 & $3.13 \mathrm{E}-07$ & 1.44 \\
\hline $3.70 \mathrm{E}-07$ & 97.90 & $7.81 \mathrm{E}-08$ & 4.49 \\
\hline $1.23 \mathrm{E}-07$ & 98.77 & $1.95 \mathrm{E}-08$ & 13.93 \\
\hline $4.12 \mathrm{E}-08$ & 96.71 & $4.88 \mathrm{E}-09$ & 35.62 \\
\hline $1.37 \mathrm{E}-08$ & 99.98 & $1.22 \mathrm{E}-09$ & 68.42 \\
\hline $4.57 \mathrm{E}-09$ & 99.46 & $3.05 \mathrm{E}-10$ & 90.41 \\
\hline $1.52 \mathrm{E}-09$ & 99.86 & $7.63 \mathrm{E}-11$ & 95.15 \\
\hline DMSO & 99.71 & DMSO & 100.29 \\
\hline
\end{tabular}

Percent enzyme inhibition against DiscoveRx KINOMEscan ${ }^{\mathrm{TM}}$ profiling service

Compound 6 was tested at $10 \mu \mathrm{M}$ in duplicate against 456 kinases (395 non-mutant kinases) in the DiscoveRx KINOMEscan ${ }^{\circledR}$ kinase profile panel [Fabian, 2005] as shown in Table S3. ATP was not used in the KINOMEscan ${ }^{\circledR}$ competition binding assay platform (http://www.discoverx.com).

Table S3. DiscoveRx kinase panel for compound 6.

\begin{tabular}{|l|c|c|}
\hline Kinase & \% Enzyme Activity & Molar Conc $(\mu \mathrm{M})$ \\
\hline ABL1(E255K)-phosphorylated & 87 & 10000 \\
\hline ABL1(F317I)-nonphosphorylated & 90 & 10000 \\
\hline ABL1(F317I)-phosphorylated & 82 & 10000 \\
\hline ABL1(F317L)-nonphosphorylated & 87 & 10000 \\
\hline ABL1(F317L)-phosphorylated & 85 & 10000 \\
\hline ABL1(H396P)-nonphosphorylated & 97 & 10000 \\
\hline ABL1(H396P)-phosphorylated & 90 & 10000 \\
\hline ABL1(M351T)-phosphorylated & 90 & 10000 \\
\hline ABL1(Q252H)-nonphosphorylated & 96 & 10000 \\
\hline ABL1(Q252H)-phosphorylated & 89 & 10000 \\
\hline ABL1(T315I)-nonphosphorylated & 91 & 10000 \\
\hline ABL1(T315I)-phosphorylated & 72 & 10000 \\
\hline ABL1(Y253F)-phosphorylated & 77 & 10000 \\
\hline ABL1-nonphosphorylated & 91 & 10000 \\
\hline ABL1-phosphorylated & 78 & 10000 \\
\hline ABL2 & 94 & 10000 \\
\hline ACVR1 & 90 & 10000 \\
\hline ACVR1B & 97 & 10000 \\
\hline ACVR2A & 94 & 10000 \\
\hline
\end{tabular}




\begin{tabular}{|c|c|c|}
\hline ACVR2B & 92 & 10000 \\
\hline ACVRL1 & 99 & 10000 \\
\hline ADCK3 & 100 & 10000 \\
\hline ADCK4 & 100 & 10000 \\
\hline AKT1 & 82 & 10000 \\
\hline AKT2 & 89 & 10000 \\
\hline AKT3 & 89 & 10000 \\
\hline ALK & 100 & 10000 \\
\hline ALK(C1156Y) & 84 & 10000 \\
\hline ALK(L1196M) & 96 & 10000 \\
\hline AMPK-alpha1 & 86 & 10000 \\
\hline AMPK-alpha2 & 93 & 10000 \\
\hline ANKK1 & 88 & 10000 \\
\hline ARK5 & 100 & 10000 \\
\hline ASK1 & 100 & 10000 \\
\hline ASK2 & 77 & 10000 \\
\hline AURKA & 84 & 10000 \\
\hline AURKB & 89 & 10000 \\
\hline AURKC & 82 & 10000 \\
\hline AXL & 92 & 10000 \\
\hline BIKE & 94 & 10000 \\
\hline BLK & 93 & 10000 \\
\hline BMPR1A & 84 & 10000 \\
\hline BMPR1B & 81 & 10000 \\
\hline BMPR2 & 83 & 10000 \\
\hline BMX & 95 & 10000 \\
\hline BRAF & 87 & 10000 \\
\hline BRAF(V600E) & 93 & 10000 \\
\hline BRK & 100 & 10000 \\
\hline BRSK1 & 100 & 10000 \\
\hline BRSK2 & 100 & 10000 \\
\hline BTK & 100 & 10000 \\
\hline BUB1 & 100 & 10000 \\
\hline CAMK1 & 52 & 10000 \\
\hline CAMK1D & 58 & 10000 \\
\hline CAMK1G & 97 & 10000 \\
\hline CAMK2A & 100 & 10000 \\
\hline CAMK2B & 100 & 10000 \\
\hline CAMK2D & 97 & 10000 \\
\hline CAMK2G & 90 & 10000 \\
\hline CAMK4 & 79 & 10000 \\
\hline CAMKK1 & 95 & 10000 \\
\hline
\end{tabular}




\begin{tabular}{|c|c|c|}
\hline CAMKK2 & 95 & 10000 \\
\hline CASK & 87 & 10000 \\
\hline CDC2L1 & 100 & 10000 \\
\hline CDC2L2 & 94 & 10000 \\
\hline CDC2L5 & 63 & 10000 \\
\hline CDK11 & 83 & 10000 \\
\hline CDK2 & 98 & 10000 \\
\hline CDK3 & 100 & 10000 \\
\hline CDK4-cyclinD1 & 100 & 10000 \\
\hline CDK4-cyclinD3 & 81 & 10000 \\
\hline CDK5 & 91 & 10000 \\
\hline CDK7 & 79 & 10000 \\
\hline CDK8 & 100 & 10000 \\
\hline CDK9 & 96 & 10000 \\
\hline CDKL1 & 97 & 10000 \\
\hline CDKL2 & 100 & 10000 \\
\hline CDKL3 & 82 & 10000 \\
\hline CDKL5 & 83 & 10000 \\
\hline CHEK1 & 99 & 10000 \\
\hline CHEK2 & 98 & 10000 \\
\hline CIT & 96 & 10000 \\
\hline CLK1 & 80 & 10000 \\
\hline CLK2 & 100 & 10000 \\
\hline CLK3 & 88 & 10000 \\
\hline CLK4 & 93 & 10000 \\
\hline CSF1R & 83 & 10000 \\
\hline CSF1R-autoinhibited & 94 & 10000 \\
\hline CSK & 98 & 10000 \\
\hline CSNK1A1 & 82 & 10000 \\
\hline CSNK1A1L & 87 & 10000 \\
\hline CSNK1D & 88 & 10000 \\
\hline CSNK1E & 86 & 10000 \\
\hline CSNK1G1 & 88 & 10000 \\
\hline CSNK1G2 & 94 & 10000 \\
\hline CSNK1G3 & 97 & 10000 \\
\hline CSNK2A1 & 96 & 10000 \\
\hline CSNK2A2 & 85 & 10000 \\
\hline CTK & 88 & 10000 \\
\hline DAPK1 & 76 & 10000 \\
\hline DAPK2 & 81 & 10000 \\
\hline DAPK3 & 83 & 10000 \\
\hline DCAMKL1 & 69 & 10000 \\
\hline
\end{tabular}




\begin{tabular}{|c|c|c|}
\hline DCAMKL2 & 92 & 10000 \\
\hline DCAMKL3 & 92 & 10000 \\
\hline DDR1 & 99 & 10000 \\
\hline DDR2 & 100 & 10000 \\
\hline DLK & 100 & 10000 \\
\hline DMPK & 88 & 10000 \\
\hline DMPK2 & 90 & 10000 \\
\hline DRAK1 & 94 & 10000 \\
\hline DRAK2 & 91 & 10000 \\
\hline DYRK1A & 84 & 10000 \\
\hline DYRK1B & 86 & 10000 \\
\hline DYRK2 & 90 & 10000 \\
\hline EGFR & 91 & 10000 \\
\hline EGFR(E746-A750del) & 94 & 10000 \\
\hline EGFR(G719C) & 97 & 10000 \\
\hline EGFR(G719S) & 97 & 10000 \\
\hline EGFR(L747-E749del, A750P) & 91 & 10000 \\
\hline EGFR(L747-S752del, P753S) & 100 & 10000 \\
\hline EGFR(L747-T751del,Sins) & 89 & 10000 \\
\hline EGFR(L858R) & 93 & 10000 \\
\hline EGFR(L858R,T790M) & 90 & 10000 \\
\hline EGFR(L861Q) & 80 & 10000 \\
\hline EGFR(S752-I759del) & 98 & 10000 \\
\hline EGFR(T790M) & 92 & 10000 \\
\hline EIF2AK1 & 89 & 10000 \\
\hline EPHA1 & 100 & 10000 \\
\hline EPHA2 & 94 & 10000 \\
\hline EPHA3 & 94 & 10000 \\
\hline EPHA4 & 82 & 10000 \\
\hline EPHA5 & 93 & 10000 \\
\hline EPHA6 & 81 & 10000 \\
\hline EPHA7 & 94 & 10000 \\
\hline EPHA8 & 96 & 10000 \\
\hline EPHB1 & 92 & 10000 \\
\hline EPHB2 & 97 & 10000 \\
\hline EPHB3 & 91 & 10000 \\
\hline EPHB4 & 93 & 10000 \\
\hline EPHB6 & 100 & 10000 \\
\hline ERBB2 & 100 & 10000 \\
\hline ERBB3 & 100 & 10000 \\
\hline ERBB4 & 100 & 10000 \\
\hline ERK1 & 97 & 10000 \\
\hline
\end{tabular}




\begin{tabular}{|c|c|c|}
\hline ERK2 & 98 & 10000 \\
\hline ERK3 & 90 & 10000 \\
\hline ERK4 & 93 & 10000 \\
\hline ERK5 & 95 & 10000 \\
\hline ERK8 & 86 & 10000 \\
\hline ERN1 & 79 & 10000 \\
\hline FAK & 96 & 10000 \\
\hline FER & 87 & 10000 \\
\hline FES & 87 & 10000 \\
\hline FGFR1 & 96 & 10000 \\
\hline FGFR2 & 100 & 10000 \\
\hline FGFR3 & 84 & 10000 \\
\hline FGFR3(G697C) & 87 & 10000 \\
\hline FGFR4 & 100 & 10000 \\
\hline FGR & 88 & 10000 \\
\hline FLT1 & 88 & 10000 \\
\hline FLT3 & 93 & 10000 \\
\hline FLT3(D835H) & 99 & 10000 \\
\hline FLT3(D835Y) & 89 & 10000 \\
\hline FLT3(ITD) & 100 & 10000 \\
\hline FLT3(K663Q) & 100 & 10000 \\
\hline FLT3(N841I) & 95 & 10000 \\
\hline FLT3(R834Q) & 100 & 10000 \\
\hline FLT3-autoinhibited & 94 & 10000 \\
\hline FLT4 & 94 & 10000 \\
\hline FRK & 100 & 10000 \\
\hline FYN & 100 & 10000 \\
\hline GAK & 100 & 10000 \\
\hline GCN2(Kin.Dom.2,S808G) & 100 & 10000 \\
\hline GRK1 & 94 & 10000 \\
\hline GRK4 & 100 & 10000 \\
\hline GRK7 & 100 & 10000 \\
\hline GSK3A & 96 & 10000 \\
\hline GSK3B & 80 & 10000 \\
\hline HASPIN & 78 & 10000 \\
\hline $\mathrm{HCK}$ & 91 & 10000 \\
\hline HIPK1 & 75 & 10000 \\
\hline HIPK2 & 88 & 10000 \\
\hline HIPK3 & 86 & 10000 \\
\hline HIPK4 & 93 & 10000 \\
\hline HPK1 & 98 & 10000 \\
\hline HUNK & 97 & 10000 \\
\hline
\end{tabular}




\begin{tabular}{|c|c|c|}
\hline ICK & 81 & 10000 \\
\hline IGF1R & 99 & 10000 \\
\hline IKK-alpha & 99 & 10000 \\
\hline IKK-beta & 77 & 10000 \\
\hline IKK-epsilon & 86 & 10000 \\
\hline INSR & 85 & 10000 \\
\hline INSRR & 98 & 10000 \\
\hline IRAK1 & 82 & 10000 \\
\hline IRAK3 & 100 & 10000 \\
\hline IRAK4 & 92 & 10000 \\
\hline ITK & 95 & 10000 \\
\hline JAK1(JH1domain-catalytic) & 100 & 10000 \\
\hline JAK1(JH2domain-pseudokinase) & 69 & 10000 \\
\hline JAK2(JH1 domain-catalytic) & 93 & 10000 \\
\hline JAK3(JH1 domain-catalytic) & 100 & 10000 \\
\hline JNK1 & 70 & 10000 \\
\hline JNK2 & 90 & 10000 \\
\hline JNK3 & 88 & 10000 \\
\hline KIT & 92 & 10000 \\
\hline KIT(A829P) & 94 & 10000 \\
\hline KIT(D816H) & 90 & 10000 \\
\hline KIT(D816V) & 92 & 10000 \\
\hline KIT(L576P) & 96 & 10000 \\
\hline KIT(V559D) & 91 & 10000 \\
\hline KIT(V559D,T670I) & 86 & 10000 \\
\hline KIT(V559D,V654A) & 96 & 10000 \\
\hline KIT-autoinhibited & 71 & 10000 \\
\hline LATS1 & 95 & 10000 \\
\hline LATS2 & 91 & 10000 \\
\hline LCK & 87 & 10000 \\
\hline LIMK1 & 77 & 10000 \\
\hline LIMK2 & 62 & 10000 \\
\hline LKB1 & 81 & 10000 \\
\hline LOK & 96 & 10000 \\
\hline LRRK2 & 86 & 10000 \\
\hline LRRK2(G2019S) & 100 & 10000 \\
\hline LTK & 90 & 10000 \\
\hline LYN & 86 & 10000 \\
\hline LZK & 92 & 10000 \\
\hline MAK & 98 & 10000 \\
\hline MAP3K1 & 87 & 10000 \\
\hline MAP3K15 & 76 & 10000 \\
\hline
\end{tabular}




\begin{tabular}{|c|c|c|}
\hline MAP3K2 & 100 & 10000 \\
\hline MAP3K3 & 73 & 10000 \\
\hline MAP3K4 & 99 & 10000 \\
\hline MAP4K2 & 94 & 10000 \\
\hline MAP4K3 & 100 & 10000 \\
\hline MAP4K4 & 90 & 10000 \\
\hline MAP4K5 & 92 & 10000 \\
\hline MAPKAPK2 & 84 & 10000 \\
\hline MAPKAPK5 & 73 & 10000 \\
\hline MARK1 & 93 & 10000 \\
\hline MARK2 & 66 & 10000 \\
\hline MARK3 & 67 & 10000 \\
\hline MARK4 & 91 & 10000 \\
\hline MAST1 & 87 & 10000 \\
\hline MEK1 & 82 & 10000 \\
\hline MEK2 & 69 & 10000 \\
\hline MEK3 & 85 & 10000 \\
\hline MEK4 & 92 & 10000 \\
\hline MEK5 & 83 & 10000 \\
\hline MEK6 & 98 & 10000 \\
\hline MELK & 98 & 10000 \\
\hline MERTK & 100 & 10000 \\
\hline MET & 90 & 10000 \\
\hline MET(M1250T) & 96 & 10000 \\
\hline MET(Y1235D) & 100 & 10000 \\
\hline MINK & 77 & 10000 \\
\hline MKK7 & 97 & 10000 \\
\hline MKNK1 & 89 & 10000 \\
\hline MKNK2 & 94 & 10000 \\
\hline MLCK & 93 & 10000 \\
\hline MLK1 & 94 & 10000 \\
\hline MLK2 & 79 & 10000 \\
\hline MLK3 & 94 & 10000 \\
\hline MRCKA & 97 & 10000 \\
\hline MRCKB & 100 & 10000 \\
\hline MST1 & 83 & 10000 \\
\hline MST1R & 93 & 10000 \\
\hline MST2 & 97 & 10000 \\
\hline MST3 & 70 & 10000 \\
\hline MST4 & 85 & 10000 \\
\hline MTOR & 99 & 10000 \\
\hline MUSK & 98 & 10000 \\
\hline
\end{tabular}




\begin{tabular}{|c|c|c|}
\hline MYLK & 94 & 10000 \\
\hline MYLK2 & 100 & 10000 \\
\hline MYLK4 & 87 & 10000 \\
\hline MYO3A & 89 & 10000 \\
\hline MYO3B & 97 & 10000 \\
\hline NDR1 & 90 & 10000 \\
\hline NDR2 & 93 & 10000 \\
\hline NEK1 & 100 & 10000 \\
\hline NEK10 & 92 & 10000 \\
\hline NEK11 & 99 & 10000 \\
\hline NEK2 & 95 & 10000 \\
\hline NEK3 & 76 & 10000 \\
\hline NEK4 & 86 & 10000 \\
\hline NEK5 & 87 & 10000 \\
\hline NEK6 & 90 & 10000 \\
\hline NEK7 & 92 & 10000 \\
\hline NEK9 & 92 & 10000 \\
\hline NIK & 95 & 10000 \\
\hline NIM1 & 96 & 10000 \\
\hline NLK & 100 & 10000 \\
\hline OSR1 & 85 & 10000 \\
\hline p38-alpha & 93 & 10000 \\
\hline p38-beta & 96 & 10000 \\
\hline p38-delta & 92 & 10000 \\
\hline p38-gamma & 77 & 10000 \\
\hline PAK1 & 96 & 10000 \\
\hline PAK2 & 96 & 10000 \\
\hline PAK3 & 92 & 10000 \\
\hline PAK4 & 85 & 10000 \\
\hline PAK6 & 97 & 10000 \\
\hline PAK7 & 96 & 10000 \\
\hline PCTK1 & 85 & 10000 \\
\hline PCTK2 & 93 & 10000 \\
\hline PCTK3 & 97 & 10000 \\
\hline PDGFRA & 88 & 10000 \\
\hline PDGFRB & 91 & 10000 \\
\hline PDPK1 & 95 & 10000 \\
\hline PFCDPK1(P.falciparum) & 87 & 10000 \\
\hline PFPK5(P.falciparum) & 100 & 10000 \\
\hline PFTAIRE2 & 94 & 10000 \\
\hline PFTK1 & 95 & 10000 \\
\hline PHKG1 & 100 & 10000 \\
\hline
\end{tabular}




\begin{tabular}{|c|c|c|}
\hline PHKG2 & 79 & 10000 \\
\hline PIK3C2B & 98 & 10000 \\
\hline PIK3C2G & 92 & 10000 \\
\hline PIK3CA & 100 & 10000 \\
\hline PIK3CA(C420R) & 77 & 10000 \\
\hline PIK3CA(E542K) & 76 & 10000 \\
\hline PIK3CA(E545A) & 81 & 10000 \\
\hline PIK3CA(E545K) & 67 & 10000 \\
\hline PIK3CA(H1047L) & 98 & 10000 \\
\hline PIK3CA(H1047Y) & 75 & 10000 \\
\hline PIK3CA(I800L) & 65 & 10000 \\
\hline PIK3CA(M1043I) & 91 & 10000 \\
\hline PIK3CA(Q546K) & 85 & 10000 \\
\hline PIK3CB & 100 & 10000 \\
\hline PIK3CD & 83 & 10000 \\
\hline PIK3CG & 88 & 10000 \\
\hline PIK4CB & 99 & 10000 \\
\hline PIM1 & 86 & 10000 \\
\hline PIM2 & 89 & 10000 \\
\hline PIM3 & 100 & 10000 \\
\hline PIP5K1A & 100 & 10000 \\
\hline PIP5K1C & 99 & 10000 \\
\hline PIP5K2B & 100 & 10000 \\
\hline PIP5K2C & 83 & 10000 \\
\hline PKAC-alpha & 95 & 10000 \\
\hline PKAC-beta & 95 & 10000 \\
\hline PKMYT1 & 100 & 10000 \\
\hline PKN1 & 81 & 10000 \\
\hline PKN2 & 98 & 10000 \\
\hline PKNB(M.tuberculosis) & 78 & 10000 \\
\hline PLK1 & 91 & 10000 \\
\hline PLK2 & 67 & 10000 \\
\hline PLK3 & 77 & 10000 \\
\hline PLK4 & 87 & 10000 \\
\hline PRKCD & 85 & 10000 \\
\hline PRKCE & 100 & 10000 \\
\hline PRKCH & 98 & 10000 \\
\hline PRKCI & 72 & 10000 \\
\hline PRKCQ & 91 & 10000 \\
\hline PRKD1 & 93 & 10000 \\
\hline PRKD2 & 95 & 10000 \\
\hline PRKD3 & 89 & 10000 \\
\hline
\end{tabular}




\begin{tabular}{|c|c|c|}
\hline PRKG1 & 100 & 10000 \\
\hline PRKG2 & 78 & 10000 \\
\hline PRKR & 100 & 10000 \\
\hline PRKX & 100 & 10000 \\
\hline PRP4 & 100 & 10000 \\
\hline PYK2 & 94 & 10000 \\
\hline QSK & 83 & 10000 \\
\hline RAF1 & 99 & 10000 \\
\hline RET & 87 & 10000 \\
\hline RET(M918T) & 96 & 10000 \\
\hline RET(V804L) & 99 & 10000 \\
\hline RET(V804M) & 100 & 10000 \\
\hline RIOK1 & 100 & 10000 \\
\hline RIOK2 & 94 & 10000 \\
\hline RIOK3 & 100 & 10000 \\
\hline RIPK1 & 0 & 10000 \\
\hline RIPK2 & 98 & 10000 \\
\hline RIPK4 & 83 & 10000 \\
\hline RIPK5 & 68 & 10000 \\
\hline ROCK1 & 94 & 10000 \\
\hline ROCK2 & 100 & 10000 \\
\hline ROS1 & 85 & 10000 \\
\hline RPS6KA4(Kin.Dom.1-N-terminal) & 97 & 10000 \\
\hline RPS6KA4(Kin.Dom.2-C-terminal) & 99 & 10000 \\
\hline RPS6KA5(Kin.Dom.1-N-terminal) & 96 & 10000 \\
\hline RPS6KA5(Kin.Dom.2-C-terminal) & 80 & 10000 \\
\hline RSK1(Kin.Dom.1-N-terminal) & 89 & 10000 \\
\hline RSK1(Kin.Dom.2-C-terminal) & 80 & 10000 \\
\hline RSK2(Kin.Dom.1-N-terminal) & 93 & 10000 \\
\hline RSK2(Kin.Dom.2-C-terminal) & 100 & 10000 \\
\hline RSK3(Kin.Dom.1-N-terminal) & 83 & 10000 \\
\hline RSK3(Kin.Dom.2-C-terminal) & 65 & 10000 \\
\hline RSK4(Kin.Dom.1-N-terminal) & 100 & 10000 \\
\hline RSK4(Kin.Dom.2-C-terminal) & 61 & 10000 \\
\hline S6K1 & 80 & 10000 \\
\hline SBK1 & 80 & 10000 \\
\hline SGK & 81 & 10000 \\
\hline SgK110 & 100 & 10000 \\
\hline SGK2 & 88 & 10000 \\
\hline SGK3 & 84 & 10000 \\
\hline SIK & 96 & 10000 \\
\hline SIK2 & 91 & 10000 \\
\hline
\end{tabular}




\begin{tabular}{|c|c|c|}
\hline SLK & 83 & 10000 \\
\hline SNARK & 92 & 10000 \\
\hline SNRK & 80 & 10000 \\
\hline SRC & 94 & 10000 \\
\hline SRMS & 75 & 10000 \\
\hline SRPK1 & 86 & 10000 \\
\hline SRPK2 & 90 & 10000 \\
\hline SRPK3 & 87 & 10000 \\
\hline STK16 & 100 & 10000 \\
\hline STK33 & 71 & 10000 \\
\hline STK35 & 96 & 10000 \\
\hline STK36 & 91 & 10000 \\
\hline STK39 & 88 & 10000 \\
\hline SYK & 66 & 10000 \\
\hline TAK1 & 76 & 10000 \\
\hline TAOK1 & 98 & 10000 \\
\hline TAOK2 & 70 & 10000 \\
\hline TAOK3 & 88 & 10000 \\
\hline TBK1 & 89 & 10000 \\
\hline TEC & 100 & 10000 \\
\hline TESK1 & 96 & 10000 \\
\hline TGFBR1 & 94 & 10000 \\
\hline TGFBR2 & 94 & 10000 \\
\hline TIE1 & 100 & 10000 \\
\hline TIE2 & 98 & 10000 \\
\hline TLK1 & 85 & 10000 \\
\hline TLK2 & 100 & 10000 \\
\hline TNIK & 93 & 10000 \\
\hline TNK1 & 76 & 10000 \\
\hline TNK2 & 86 & 10000 \\
\hline TNNI3K & 100 & 10000 \\
\hline TRKA & 100 & 10000 \\
\hline TRKB & 89 & 10000 \\
\hline TRKC & 97 & 10000 \\
\hline TRPM6 & 87 & 10000 \\
\hline TSSK1B & 83 & 10000 \\
\hline TTK & 53 & 10000 \\
\hline TXK & 93 & 10000 \\
\hline TYK2(JH1domain-catalytic) & 100 & 10000 \\
\hline TYK2(JH2domain-pseudokinase) & 78 & 10000 \\
\hline TYRO3 & 94 & 10000 \\
\hline ULK1 & 96 & 10000 \\
\hline
\end{tabular}




\begin{tabular}{|l|c|l|}
\hline ULK2 & 88 & 10000 \\
\hline ULK3 & 79 & 10000 \\
\hline VEGFR2 & 94 & 10000 \\
\hline VRK2 & 76 & 10000 \\
\hline WEE1 & 90 & 10000 \\
\hline WEE2 & 95 & 10000 \\
\hline WNK1 & 89 & 10000 \\
\hline WNK3 & 96 & 10000 \\
\hline YANK1 & 82 & 10000 \\
\hline YANK2 & 88 & 10000 \\
\hline YANK3 & 87 & 10000 \\
\hline YES & 88 & 10000 \\
\hline YSK1 & 100 & 10000 \\
\hline YSK4 & 97 & 10000 \\
\hline ZAK & 93 & 10000 \\
\hline ZAP70 & 99 & 10000 \\
\hline
\end{tabular}

Inhibition of human, monkey, rabbit, rat, dog, mouse, and minipig RIP1 activity in the fluorescence polarization (FP) assay

Compound 6 was tested against six nonhuman species of RIP1 in FP binding assays using the method decribed in Harris et al. (2016). The mean IC50 from a minimum of duplicate determinations is summarized in Table S4. Values for human and monkey RIP1 are at the lower limit of sensitivity (ca. $10 \mathrm{nM}$ ). Using the tight binding potency of $6.3 \mathrm{nM}$ reported in Table 1 the species selectivity is underestimated by ca. 3 fold (e.g., rabbit is 380 -fold less potent than human).

Table S4. RIP1 Species Selectivity of Compound 6.

\begin{tabular}{|c|c|c|}
\hline Species & $\mathrm{RIP1} \mathrm{FP} \mathrm{IC}_{50}(\mu \mathrm{M})$ & Fold \\
\hline Human & 0.016 & 1 \\
\hline Monkey & 0.026 & 1.6 \\
\hline Rabbit & 2.4 & $>190$ \\
\hline Rat & $>3.1$ & 440 \\
\hline Dog & 7.1 & $>625$ \\
\hline Mouse & $>10$ & $>625$ \\
\hline Mini Pig & $>10$ & \\
\hline
\end{tabular}




\section{Compound 6 RIP1 co-crystallization}

\section{Methods:}

Crystals of the RIP1 complex with benzazepinone $\mathbf{6}$ were obtained by co-crystallization using sitting drop vapor diffusion with all sample manipulation carried out at $4{ }^{\circ} \mathrm{C}$ or over ice. $100 \mathrm{~nL}$ drops of the protein at $14.8 \mathrm{mg} / \mathrm{ml}$ in the storage buffer $(25 \mathrm{mM}$ Tris-HCl, $150 \mathrm{mM} \mathrm{NaCl}, 1 \mathrm{mM}$ DTT, $10 \%$ glycerol, pH7.5) with $4 \mathrm{mM}$ benzazepinone 6 (dissolved in DMSO) were dispensed using a Mosquito dispensing robot into a 96 well plate and incubated against the Qiagen PEGS I crystallization screening kit from which 150nL was dispensed on top of the protein drop. Crystals were obtained from solution 34 (100mM MES pH 6.5, 25\% PEG 8k) and grew to full size over approximately one week. Crystals were quickly transferred through a $10 \mu \mathrm{L}$ drop containing precipitant solution, $10 \%$ ethylene glycol and $4 \mathrm{mM}$ benzazepinone 6 before plunge freezing into liquid nitrogen.

Data was collected at the ESRF synchrotron in Grenoble, France on beamline ID29 using a Pilatus 6M detector where $180^{\circ}$ of data was collected using a oscillation increment of $0.2^{\circ}$. Data processing was carried out using the synchrotrons implementation of the Global Phasing program autoPROC (Acta Cryst. D67, 293-302 (2011)).

Structure determination was done by molecular replacement using the atomic coordinates of RIP1 kinase domain with Necrostatin-4 (PDB code 4ITJ) as a search model.

Refinement was carried out with the Global Phasing program Buster (Acta Cryst. D68, 368-380 (2012)) with a previously solved but undisclosed higher resolution target structure utilized for structural restraints. The chemical library for benzazepinone 6 was generated with phenix.elbow (Acta Cryst. D66, 213-221 (2010)) modified by the Cambridge Crystallographic Data Centre program Mogul. All model building was carried out with COOT (Acta Cryst D66, 486-501, 2010) and figures generated utilizing the CCP4 program CCP4MG (Acta Cryst. D67, 386-394 (2011)).

Coordinates and structure factors for the cocrystal structure of RIP1 (1-294, C34A, C127A, C233A, C240A) and benzoxazepinone 6 have been deposited in the Protein Data Bank with the accession number 6RLN.

Table S5: X-ray diffraction processing and refinement statistics for the RIP1 benzazepinone 6 complex structure.

\begin{tabular}{|c|c|c|c|}
\hline & Overall & Innershell & Outershell \\
\hline Low Res Limit $(\AA)$ & 48.83 & 48.83 & 2.97 \\
\hline High Res Limit $(\AA)$ & 2.87 & 11.12 & 2.87 \\
\hline Rmerge (all) & 0.064 & 0.028 & 1.188 \\
\hline Mean(I/oI) & 17.6 & 50.9 & 1.5 \\
\hline Observations (unique) & $99490(15475)$ & $1651(325)$ & $9183(1420)$ \\
\hline
\end{tabular}




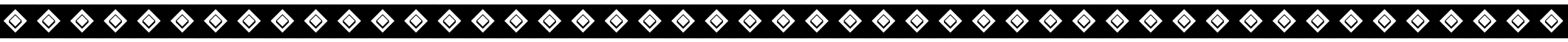

\begin{tabular}{|c|c|c|c|}
\hline Completeness & 99.4 & 98.8 & 95.3 \\
\hline Multiplicity & 6.4 & 5.1 & 6.5 \\
\hline Space Group & \multicolumn{3}{|c|}{ P212121 } \\
\hline Unit Cell Dimensions & $101.840 \quad 130.790$ & 48.83090 .0090 .0090 .00 \\
\hline R-factor (R-Free) & \multicolumn{3}{|c|}{$0.1939(0.2318)$} \\
\hline
\end{tabular}

Figure S4: The binding orientation of benzazepinone 6 in the active site pocket of RIP1 produced by single crystal X-ray crystallography with associated omit map electron density contoured at $3 \sigma$ and a resolution of $2.87 \AA$.

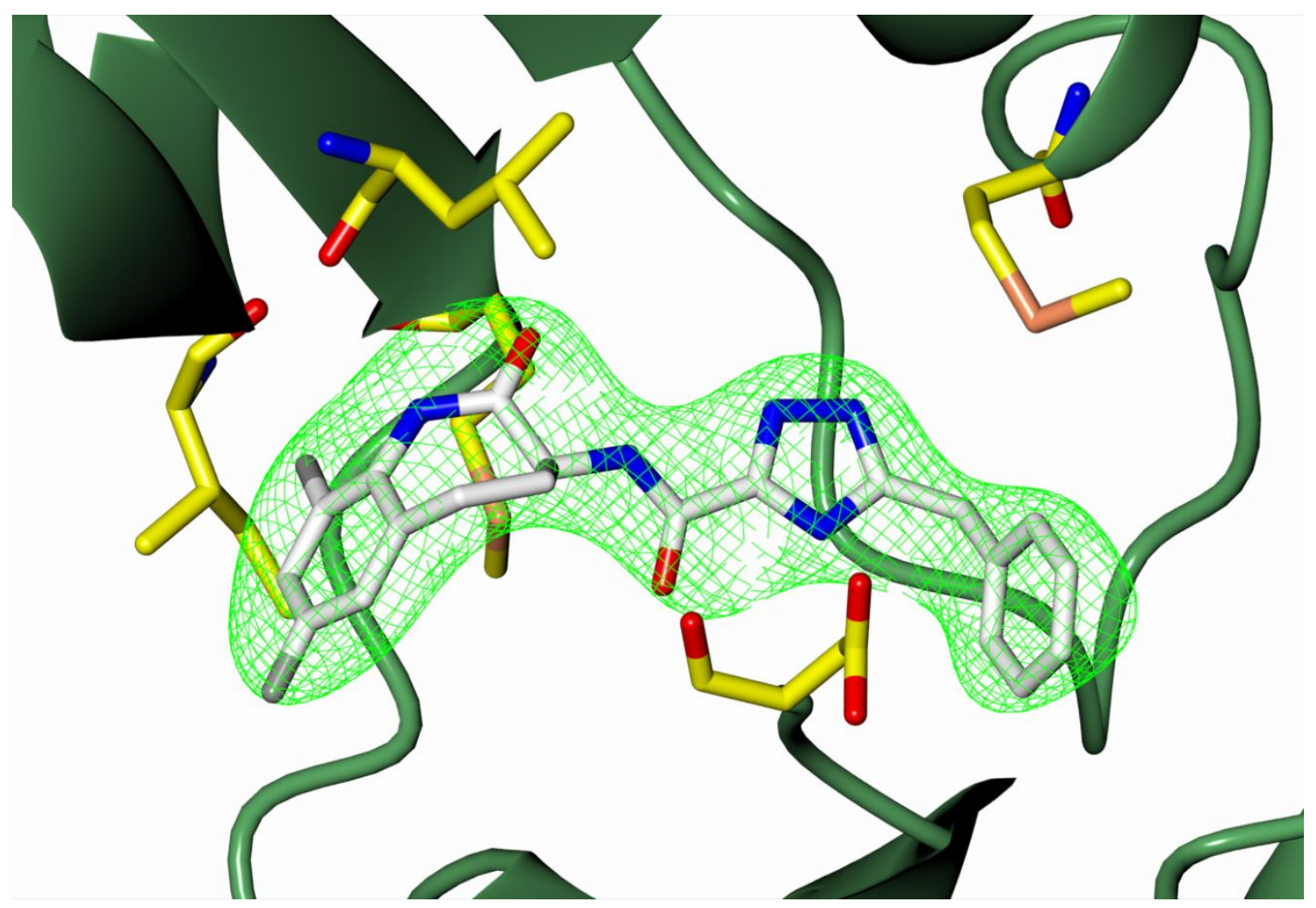

\section{Compound 6: rat tissue distribution, permeability and p-gp substrate evaluation, hepataocyte turnover, metabolite ID and human PK/PD prediction.}

Tissue Distribution of compound $\mathbf{6}$ in the male Han Wistar rat via constant intravenous infusion over 4 hours at a dose of $2.3 \mathrm{mg} / \mathrm{kg}$ (dosed in 20\% Cavitron; 5\% DMSO at dose volume of $4 \mathrm{~mL} / \mathrm{kg}$ ). At the end of the infusion, animals were euthanized and tissues were collected (brain, heart, kidney, liver, colon, skin and eyes). Homogenates were prepared in acetonitrile. Tissue homogenate concentrations were 
determined based on a standard curve prepared in an identical fashion to the study animal tissue homogenates, using a tissue specimen from an untreated control rat. The tissue-to-blood ratio for each compound was calculated by dividing tissue concentration (expressed as ng compound/g tissue) by the approximate steady-state blood concentration (Table S6).

Table S6. Tissue distribution of compound 6

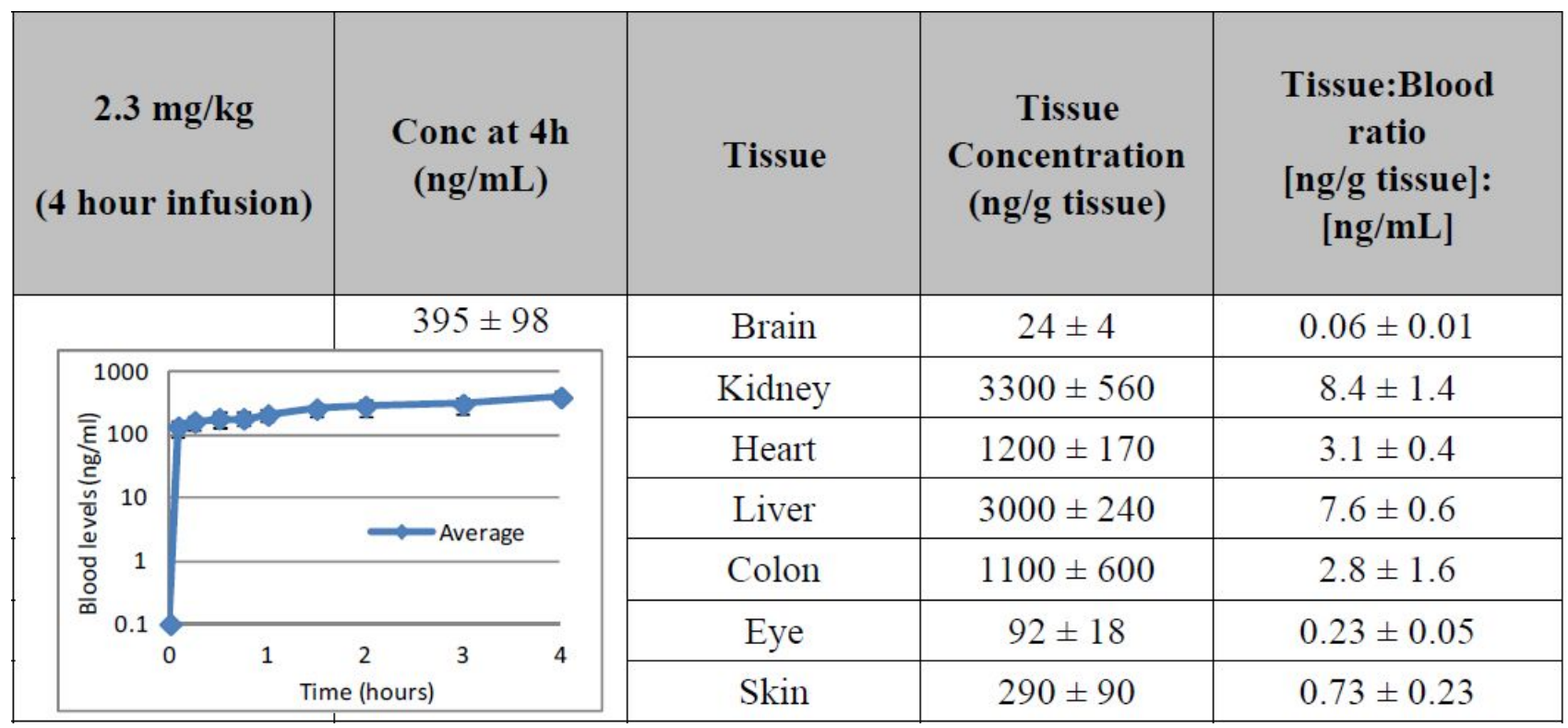

Compound 6 was evaluated for permeability across MDR1-MDCK cell monolayers with and without the P-gp inhibitor cyclosporin A (CSA). P-gp substrate is classified as positive if the efflux ratio $>3.0$ in the absence of inhibitor and $\sim 1$ in the presence of inhibitor (Table S7).

Table S7. MDCK permeability of compound 6

\begin{tabular}{llccc}
\hline Cell Line & Treatment & \multicolumn{2}{c}{ Papp $(\mathrm{nm} / \mathrm{s})$} & Efflux Ratio \\
& & A-B & B-A & B-A/A-B \\
\hline MDR1-MDCK & Compound 6 & 3.4 & 386 & 115 \\
& Compound 6 + PgP Inhibitor & 67.4 & 58.5 & 0.90 \\
\hline
\end{tabular}

In vitro evaluation of metabolic stability of compound $\mathbf{6}$ in the presence of NADPH, indicated moderate turnover in the rat and low turnover in both monkey and human hepatocytes as shown Table S8.

Table S8. Hepatocyte turnover of compound $\mathbf{6}$. Human hepatocytes were from mixed gender, whereas rat and monkey were from male only. 


\begin{tabular}{lccc}
\hline Species & Rat & Monkey & Human \\
\hline $\begin{array}{l}\text { Hepatocyte Clearance } \\
(\mathrm{mL} / \mathrm{min} / \mathrm{g} \text { Liver })\end{array}$ & 1.9 & $<0.50$ & $<0.50$ \\
\hline
\end{tabular}

Allometric scaling and in vitro to in vivo extrapolations with and with-out effects of free fraction were used to generate predictions of human PK parameters (Table S9).

Table S9. Average predicted human PK profile of 6 based on PK Predictor Pro software.

\begin{tabular}{cccc}
\hline Parameter & Average & $+95 \%$ & $-95 \%$ \\
\hline Clearance $(\mathrm{mL} / \mathrm{min} / \mathrm{kg})$ & 4.6 & 5.8 & 3.4 \\
Volume $(\mathrm{L} / \mathrm{kg})$ & 1.3 & 1.5 & 1.1 \\
Half life $(\mathrm{h})^{*}$ & 3.3 & $\mid$ & \\
Bioavailability (\%) & 83 & 87 & 79
\end{tabular}

* Half-life based on reconstructed PK profiles.

The predicted human PK/PD was modelled using the predicted human PK profile along with human whole blood activity as shown in Figure S5.

Figure S5. Predicted human PD dose effect levels of benzaepinone 6 at $273 \mathrm{mg}$ once daily and $40 \mathrm{mg}$ twice daily, maintaining 90\% RIP1 inhibition levels over 24 hours. 


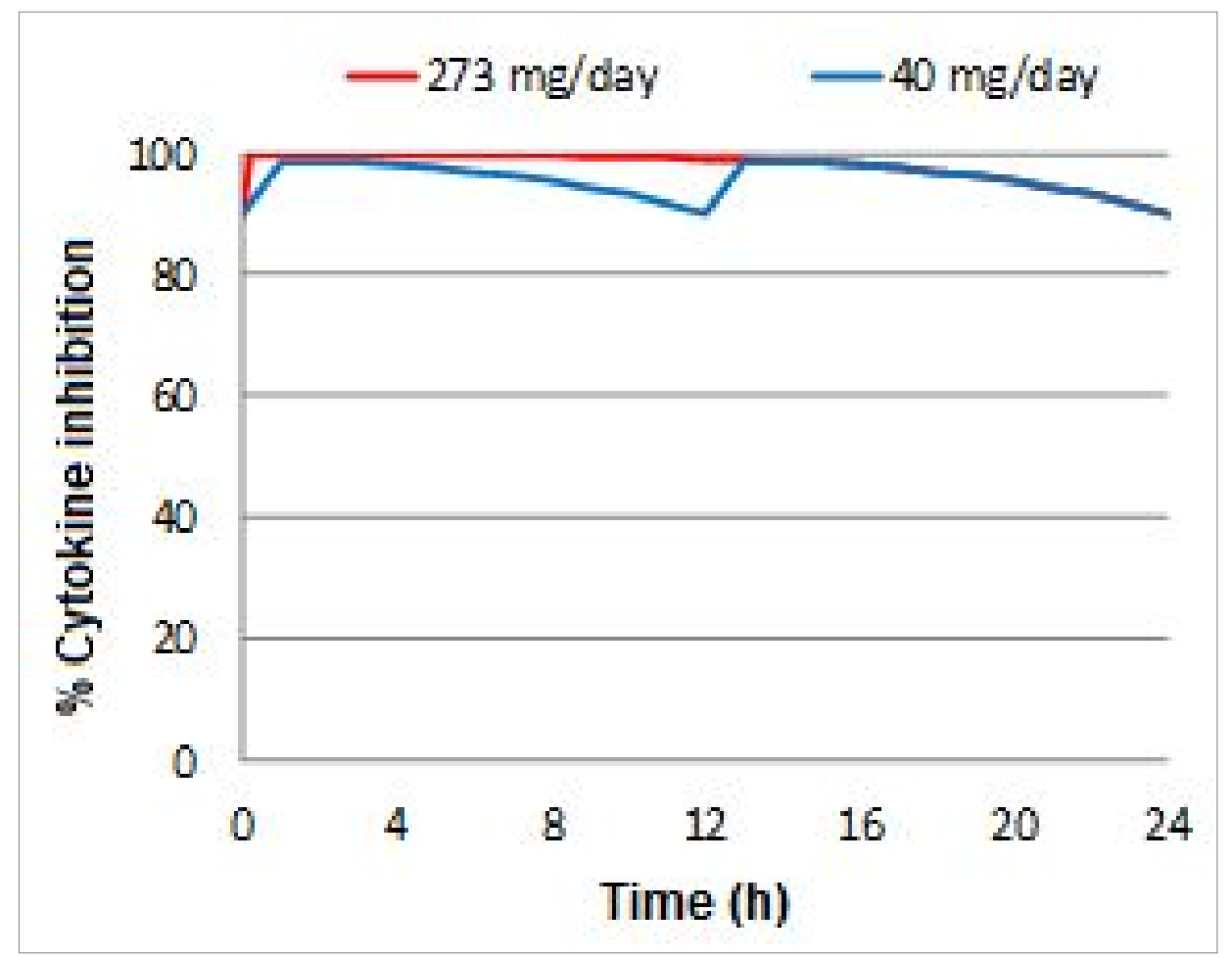

\section{Additional PDOTS evaluation.}

PDOTS prepared from tumors from pancreatic adenocarcinoma, colorectal, breast and gastric cancer patients treated with compound $\mathbf{6}$ show a trend toward increased effector-memory CD8+ T cells and TNF $\alpha$ expression, although these markers failed to reach statistical significance in this study (Figure S6). Compound 6 was dissolved to a concentration of $10 \mu \mathrm{M}$ in DMSO and underwent 1:200 dilution in culture medium to a final concentration of $0.5 \mathrm{nM}$. Vehicle control was a similar $0.5 \%$ DMSO solution in culture medium.

Figure S6. PDOTS prepared from tumors from pancreatic adenocarcinoma, colorectal, breast and gastric cancer patients treated with compound $\mathbf{6}$. 

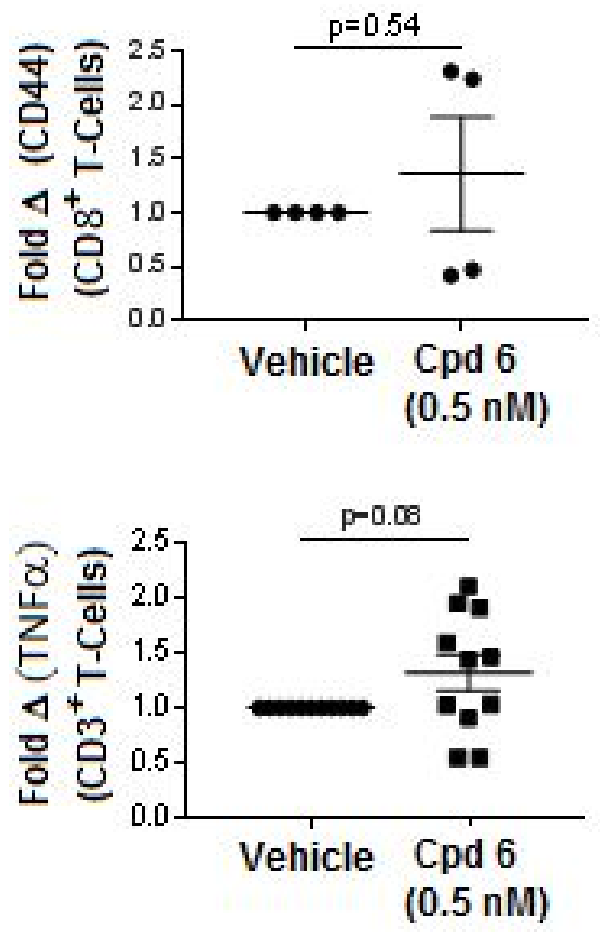
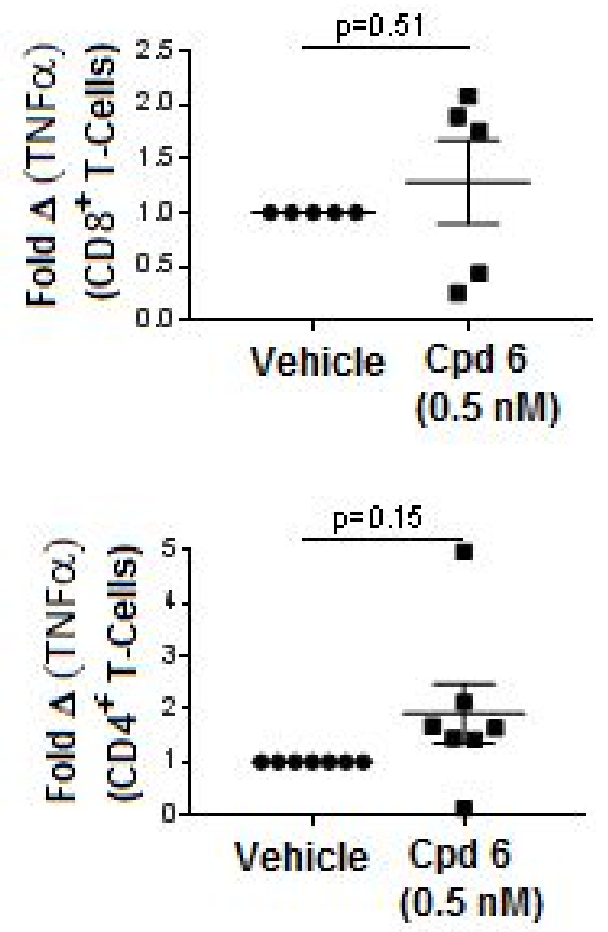

\section{References}

Adams, P. D.; Afonine, P. V.; Bunkoczi, G.; Chen, V. B.; Davis, I. W.; Echols, N.; Headd, J. J.; Hung, L. W.; Kapral, G. J.; Grosse-Kunstleve, R. W.; McCoy, A. J.; Moriarty, N. W.; Oeffner, R.; Read, R. J.; Richardson, D. C.; Richardson, J. S.; Terwilliger, T. C.; Zwart, P. H. PHENIX: a comprehensive Pythonbased system for macromolecular structure solution. Acta Crystallogr. D. Biol Crystallogr. 2010, 66, 213221.

Bricogne, G. BUSTER. 2013. Cambridge, UK, Global Phasing Ltd. (Computer Program)

Degterev, A.; Hitomi, J.; Germscheid, M.; Ch'en, I. L.; Korkina, O.; Teng, X.; Abbott, D.; Cuny, G. D.; Yuan, C.; Wagner, G.; Hedrick, S. M.; Gerber, S. A.; Lugovskoy, A.; Yuan, J. Identification of RIP1 kinase as a specific cellular target of necrostatins. Nat. Chem. Biol. 2008, 4, 313-321.

Fabian M. A., Biggs W H 3rd, Treiber D K, Atteridge C E, Azimioara M D, Benedetti M G, Carter T A, Ciceri P, Edeen P T, Floyd M, Ford J M, Galvin M, Gerlach J L, Grotzfeld R M, Herrgard S, Insko D E, Insko M A, Lai A G, Lélias J M, Mehta S A, Milanov Z V, Velasco A M, Wodicka L M, Patel H K, Zarrinkar P P, Lockhart D J. A small molecule-kinase interaction map for clinical kinase inhibitors. Nat. Biotechnol. 2005, 23, 329-336.

Harris, P. A.; Bandyopadhyay, D.; Berger, S. B.; Campobasso, N.; Capriotti, C. A.; Cox, J. A.; Dare, L.; Finger, J. N.; Hoffman, S. J.; Kahler, K. M.; Lehr, R.; Lich, J. D.; Nagilla, R.; Nolte, R. T.; Ouellette, M. T.; Pao, C. S.; Schaeffer, M. C.; Smallwood, A.; Sun, H. H.; Swift, B. A.; Totoritis, R. D.; Ward, P.; Marquis, R. W.; Bertin, J.; Gough, P. J. Discovery of Small Molecule RIP1 Kinase Inhibitors for the Treatment of Pathologies Associated with Necroptosis. ACS Med. Chem. Lett. 2013, 4, 1238-1243. 
Harris, P. A.; King, B. W.; Bandyopadhyay, D.; Berger, S. B.; Campobasso, N.; Capriotti, C. A.; Cox, J. A.; Dare, L.; Dong, X.; Finger, J. N.; Grady, L. C.; Hoffman, S. J.; Jeong, J. U.; Kang, J.; Kasparcova, V.; Lakdawala, A. S.; Lehr, R.; McNulty, D.E.; Nagilla, R.; Ouellette, M. T.; Pao, C. S.; Rendina, A. R.; Schaeffer, M. C.; Summerfield, J. D.; Swift, B.A.; Totoritis, R.D.; Ward, P.; Zhang, A.; Zhang, D.; Marquis, R. W.; Bertin, J.; Gough, P. J. DNA-Encoded Library Screening Identifies Benzo[b][1,4]oxazepin-4-ones as Highly Potent and Monoselective Receptor Interacting Protein 1 Kinase Inhibitors. J. Med. Chem. 2016, 59, 2163-2178.

Jameson, D. M., Mocz, G. Methods Mol. Biol. (Totowa, NJ, U.S.) 2005, 305, 301

Kabsch, W. XDS. Acta Cryst. 2010, D66, 125-132.

Kestranek, A., Chervenak, A., Longenberger, J., Placko, S. Chemiluminescent nitrogen detection (CLND) to measure kinetic aqueous solubility. Curr Protoc Chem Biol. 2013, 5, 269-280.

Li, L.; Thomas, R. M.; Suzuki, H.; De Brabander, J. K.; Wang, X.; Harran, P. G. A Small Molecule Smac Mimic Potentiates TRAIL and TNFalpha-mediated Cell Death. Science 2004, 305, 1471-1474.

Tummino, P.J., Copeland, R.A. Residence Time of Receptor-Ligand Complexes and Its Effect on Biological Function. Biochemistry 2008, 47, 5481-5492.

Valkó, K. Chromatographic hydrophobicity index by fast-gradient RP-HPLC: a high-throughput alternative to $\log$ P/log D. Anal. Chem. 1997, 69, 2022-2029.

Wasilko D., Lee S.E. TIPS: Titerless Infected Cells Preservation and Scale up. BioProcessing. 2006, Fall, $2-32$.

Williams, W.W., Morrison, J.F. The Kinetics of Reversible Tight-Binding Inhibition. Meth. Enzymol. 1979, 63, 437-467.

Winn, M. D., Ballard, C. C., Cowtan, K. D., Dodson, E. J., Emsley, P., Evans, P. R., Keegan, R. M., Krissinel, E. B., Leslie, A. G. W., McCoy, A. McNicholas, S. J., Murshudov, G. N., Pannu, N. S., Potterton, E. A., Powell, H. R., Read, R. J., Vagin A., Wilson K. S. Overview of the CCP4 suite and current developments Acta. Cryst. 2011, D67, 235-242.

Xie, T.; Peng, W.; Liu, Y.; Yan, C.; Maki, J.; Degterev, A.; Yuan, J.; Shi, Y. Structural basis of RIP1 inhibition by necrostatins. Structure 2013, 21, 493-499. 